\title{
Assimilation of preexisting Pleistocene intrusions at Long Valley by periodic magma recharge accelerates rhyolite generation: rethinking the remelting model
}

\author{
Justin I. Simon • Dominique Weis • Donald J. DePaolo • \\ Paul R. Renne • Roland Mundil • Axel K. Schmitt
}

Received: 11 July 2013/Accepted: 28 November 2013/Published online: 16 January 2014

(C) The Author(s) 2014. This article is published with open access at Springerlink.com

\begin{abstract}
Rhyolite flows and tuffs from the Long Valley area of California, which were erupted over a two-millionyear time period, exhibit systematic trends in $\mathrm{Nd}, \mathrm{Hf}$, and $\mathrm{Pb}$ isotopes, trace element composition, erupted volume, and inferred magma residence time that provide evidence for a new model for the production of large volumes of silica-rich magma. Key constraints come from geochronology of zircon crystal populations combined with a refined eruption chronology from $\mathrm{Ar}-\mathrm{Ar}$ geochronology; together these data give better estimates of magma residence time that can be evaluated in the context of changing magma compositions. Here, we report $\mathrm{Hf}, \mathrm{Nd}$, and $\mathrm{Sr}$ isotopes, major and trace element compositions, ${ }^{40} \mathrm{Ar} /{ }^{39} \mathrm{Ar}$ ages, and $\mathrm{U}-\mathrm{Pb}$ zircon ages that combined with existing data suggest that the chronology and geochemistry of Long Valley rhyolites can be explained by a dynamic interaction
\end{abstract}

Communicated by T L. Grove.

Electronic supplementary material The online version of this article (doi:10.1007/s00410-013-0955-5) contains supplementary material, which is available to authorized users.

\section{J. I. Simon $(\bowtie)$}

Center for Isotope Cosmochemistry and Geochronology, Astromaterials Research Office KR111, NASA Johnson Space Center, Houston, TX 770058, USA

e-mail: Justin.I.Simon@NASA.gov

D. Weis

Department of Earth, Ocean, and Atmospheric Sciences, Pacific Centre for Isotope and Geochemical Research, University of British Columbia, Vancouver, BC, Canada

D. J. DePaolo

Department of Earth and Planetary Science, Center for Isotope Geochemistry, University of California, Berkeley, CA 94720, USA of crustal and mantle-derived magma. The large volume Bishop Tuff represents the culmination of a period of increased mantle-derived magma input to the Long Valley volcanic system; the effect of this input continued into earliest postcaldera time. As the postcaldera evolution of the system continued, new and less primitive crustalderived magmas dominated the system. A mixture of varying amounts of more mafic mantle-derived and felsic crustal-derived magmas with recently crystallized granitic plutonic materials offers the best explanation for the observed chronology, secular shifts in $\mathrm{Hf}$ and $\mathrm{Nd}$ isotopes, and the apparently low zircon crystallization and saturation temperatures as compared to $\mathrm{Fe}-\mathrm{Ti}$ oxide eruption temperatures. This scenario in which transient crustal magma bodies remained molten for varying time periods, fed eruptions before solidification, and were then remelted by fresh recharge provides a realistic conceptual framework that can explain the isotopic and geochemical evidence. General relationships between crustal residence times and magma sources are that: (1) precaldera rhyolites had long crustal magma residence times and high crustal affinity, (2) the caldera-related Bishop Tuff and early postcaldera

D. J. DePaolo

Lawrence Berkeley National Laboratory, Berkeley, CA 94720 ,

USA

P. R. Renne $\cdot$ R. Mundil

Berkeley Geochronology Center, Berkeley, CA 94709, USA

P. R. Renne

Department of Earth and Planetary Science, University of

California, Berkeley, CA 94720, USA

A. K. Schmitt

Department of Earth and Space Sciences, University of

California, Los Angeles, CA 90095, USA 
rhyolites have lower crustal affinity and short magma residence times, and (3) later postcaldera rhyolites again have stronger crustal signatures and longer magma residence times.

Keywords Long Valley · Timescales · Silicic magma processes $\cdot$ Isotopes $\cdot$ Geochronology $\cdot$ Supervolcano

\section{Introduction}

The dynamics by which silicic magmas are generated in continental volcanic centers remain debated. This is due to their complex formation processes involving crust and mantle source components, lack of direct observations of the physical nature in which they reside in the crust, and ambiguities regarding their temporal evolution and extent to which they have a direct petrogenetic relationship with plutonic rocks. Canonical models propose efficient liquid separation from a crystal mush (e.g., Bachmann and Bergantz 2004; Hildreth and Wilson 2007) in which granitoids reflect crystal cumulates from which the silicic melts have been largely removed before or during eruption (Bacon and Lowenstern 2005; Johnson et al. 1989; Lipman 2007). Such models imply that associated with the generation of ignimbrite extrusions are significant volumes of subvolcanic magma that solidified as plutons that may be up to an order of magnitude larger than the erupted material (e.g., Bachmann et al. 2007; Halliday et al. 1989; Lipman 2007). The opposing views suggest that shallowly emplaced granitoids are often not the unerupted portion of volcanic rocks (Glazner et al. 2008), that plutons accumulate incrementally (Coleman et al. 2004; Davis et al. 2012), and that there are no long-lived magma chambers (e.g., Sparks et al. 1990). Inextricably linked to these models are issues related to the time interval over which such evolved magmas are stored and rejuvenated in the crust.

Coeval caldera collapse and ignimbrite eruption are conventionally thought to result from the partial evacuation of voluminous differentiated magma chambers in the shallow crust (Smith, 1979). Long-term eruption rates (Crisp 1984; Spera and Crisp 1981; White et al. 2006) and early compilation studies of crystal ages and crystal size distribution analysis (CSD) indicate that magma storage time tends to increase exponentially as $\mathrm{SiO}_{2}$ and stored magma volume increase (Hawkesworth et al. 2004; Reid 2003). These observations have been used to support the idea that longer magma storage times allow for evolved magmas to form and, in turn, result in longer repose periods associated with more felsic magmas-consistent with the long-lived mush magma chamber model. Yet, some recent investigations suggest that large volumes of silicic melts may be stored for intervals of time that are considerably shorter than the repose intervals typically seen between major silicic eruptions (Crowley et al. 2007; Druitt et al. 2012; Reid 2008; Reid and Coath 2000; Simon and Reid 2005; Simon et al. 2008a, b, 2009) or the rates of incremental emplacement of large plutonic suites (Coleman et al. 2004; Glazner et al. 2004; Matzel et al. 2006; Michel et al. 2008; Mills and Coleman 2013; Tappa et al. 2011).

Related to protracted magma residence time are the thermal requirements needed to maintain conditions where magma will remain at least partially molten in the crust (e.g., Annen 2009; Glazner et al. 2004). The primary parameters that dictate subvolcanic temperature conditions are the ambient crustal temperature (geothermal gradient) and the supply rate of basaltic magma to the volcanic system from the mantle. Because crustal and mantle reservoirs often have distinct isotopic compositions (e.g., $\mathrm{Nd}$ and $\mathrm{Hf}$ ), these signatures can be used to track the source components of felsic magmas. High mafic magma influx into the crust and low crustal temperatures favors the formation of silicic magmas with mantle-like isotopic signatures, whereas low mafic input and high crustal temperatures favor the generation of melts that are relatively undiluted with mantle-derived magma and which therefore have more crustal isotopic signatures. Likewise, the rejuvenation rate of long-lived magmatic systems by more primitive magma(s) can be investigated by the rate at which the isotopic compositions of spatially related silicic extrusions change over time (DePaolo et al. 1992; Perry et al. 1993).

Here, we address the temporal evolution of silicic magmas at Long Valley caldera, California (Fig. 1), the "supervolcano" that produced the Bishop Tuff. Our goal is to understand how the caldera-forming Bishop Tuff magmas relate to those erupted as pre- and postcaldera rhyolites. This is accomplished primarily by integrating new $\mathrm{Hf}$ and $\mathrm{Nd}$ isotopic data and compositional data with literature $\mathrm{Nd}$ isotopic data (Davies and Halliday 1998; Davies et al. 1994; Heumann and Davies 1997) and new and published ${ }^{40} \mathrm{Ar} /{ }^{39} \mathrm{Ar}$ eruption ages and U-Pb zircon crystallization ages (Mankinen et al. 1986; Reid et al. 1997; Simon and Reid 2005; Simon et al. 2007, 2008b, 2009). New data are reported for precaldera rhyolite samples collected for previous investigations (Simon and Reid 2005; Simon et al. 2007) and from new samples collected from postcaldera rhyolites and the Bishop Tuff specifically for this study. Temporal variations of $\mathrm{Hf}$ and $\mathrm{Nd}$ isotope and trace element ratios (e.g., $\mathrm{U} / \mathrm{Th}$ and $\mathrm{La} / \mathrm{Nd}$ ) of the rhyolites, and in some cases their zircon crystals, are used to probe the differentiation, physical nature, and ultimately the dynamics of the long-lived volcanic system. Given the relatively short time intervals measured between preeruption crystallization and eruption ages, we suggest that some 
Fig. 1 Simplified geologic maps of the Long Valley caldera (top) and surrounding area (bottom) showing the sample locations of the studied rhyolites, including the calderarelated Bishop Tuff, precaldera Glass Mountain domes and flows, and postcaldera rhyolites. Also shown are the locations of Deer Mountain and South Deadman Domes. The maps were derived by overlaying the map of Bailey (1989) on the digital topography provided by Google Earth ${ }^{\circledR}$. Specific sample latitude and longitude provided in Tables 1 and 3

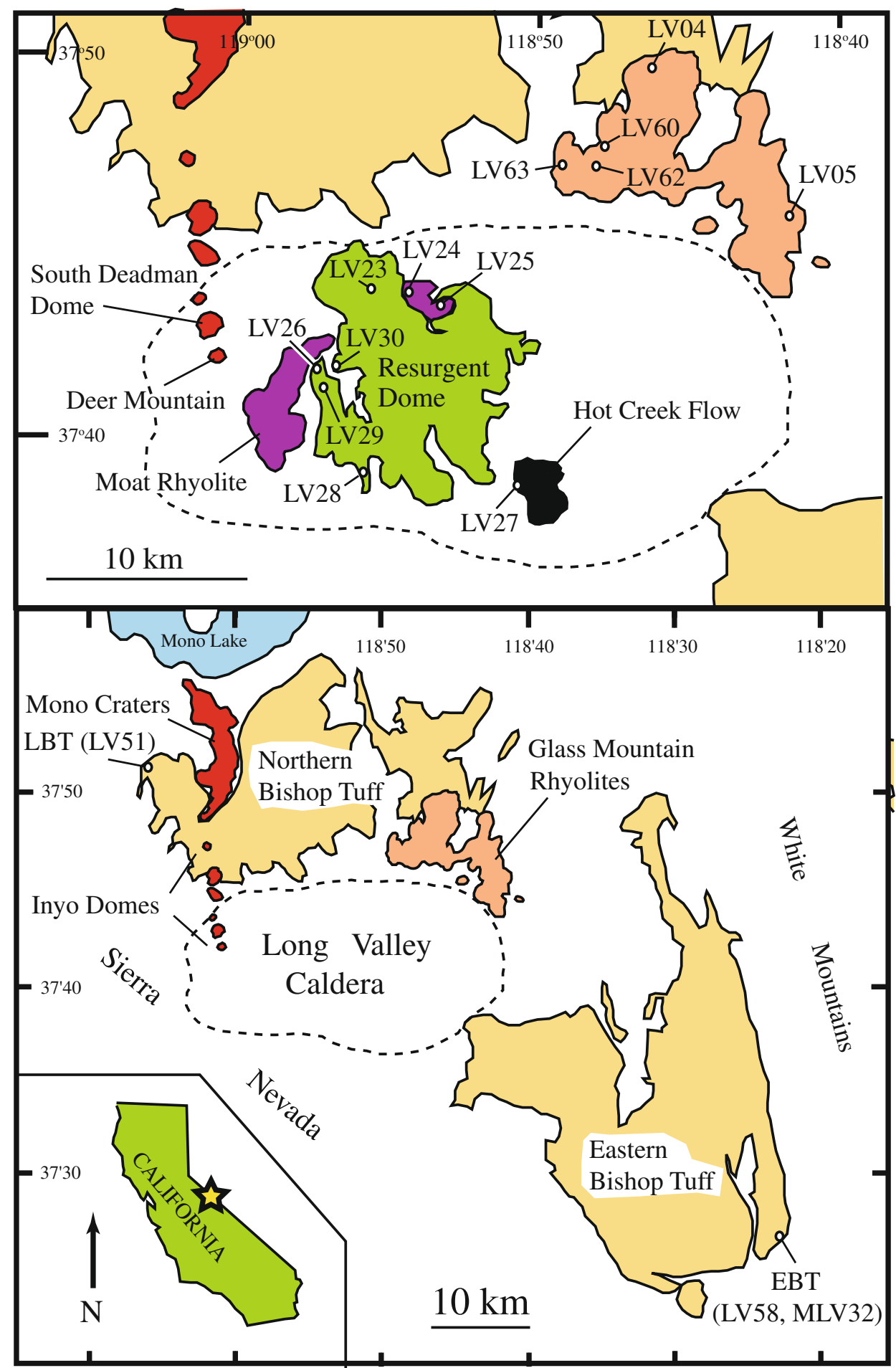

rhyolite magmas at Long Valley were produced rapidly. Of importance is the fact that the age data provide little evidence for longer magma storage times for larger eruptions, in particular the Bishop Tuff (e.g., Crowley et al. 2007; Simon and Reid 2005; Simon et al. 2008a, b). Additionally, more primitive $\mathrm{Hf}$ and $\mathrm{Nd}$ isotopic and trace element signatures tend to be correlated with larger extruded magma volumes implying that mantle-derived influx expedites both the production of rhyolitic magma and its eruption at Long Valley. These results are difficult to reconcile with conventional ideas that large eruptions are derived from gradual buildup of large, long-lived, shallow magma bodies. Rather, they imply that the production of rhyolite magmas was accelerated by emplacement or underplating 


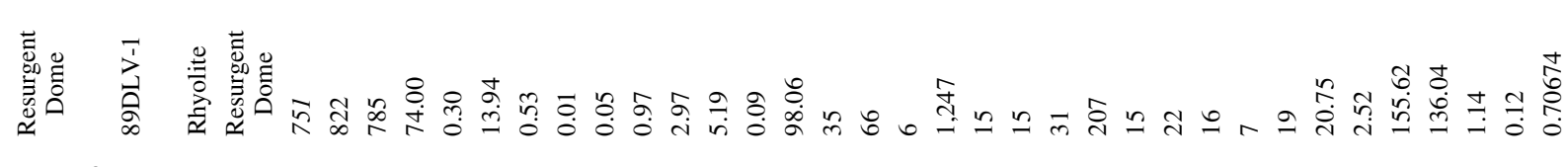

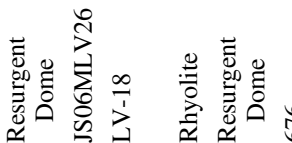

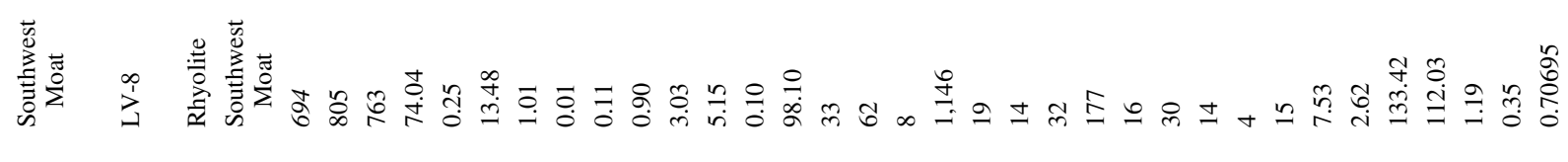

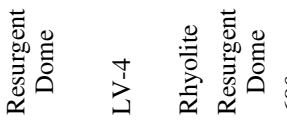

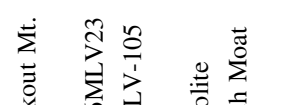

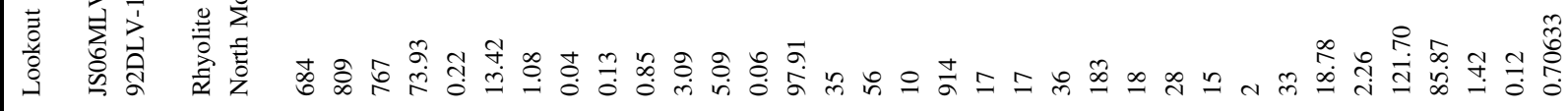

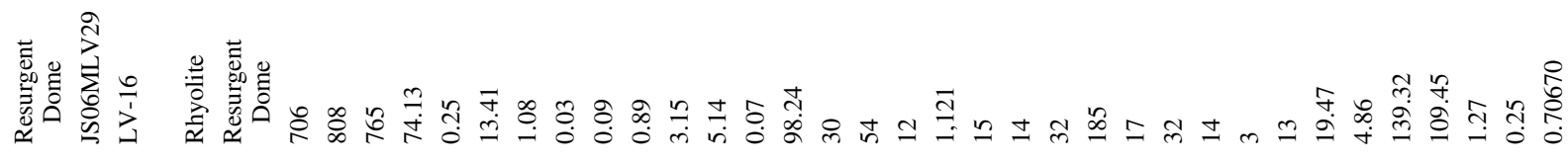

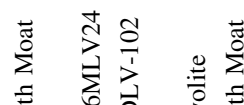

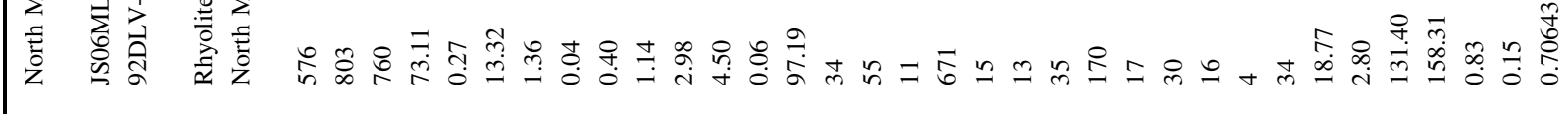
帘

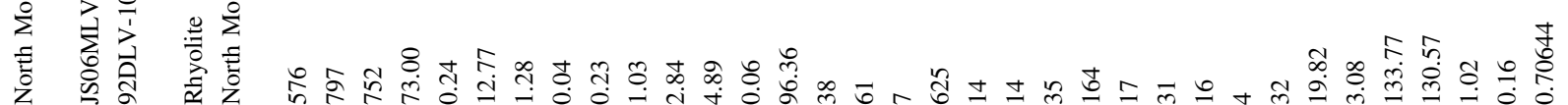

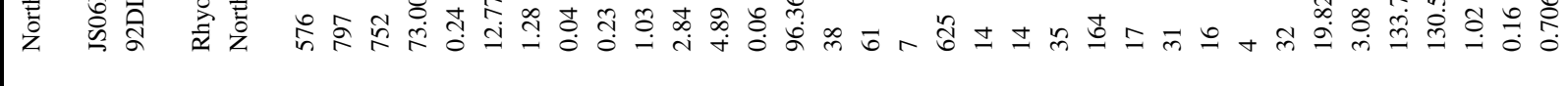

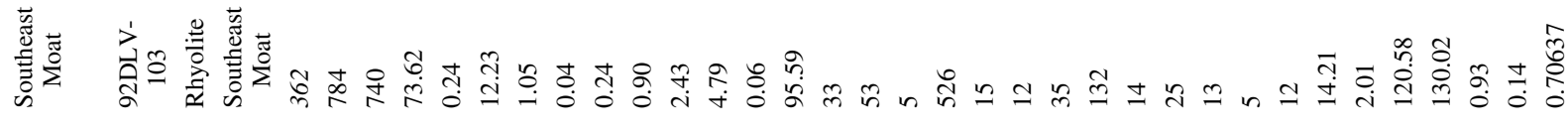

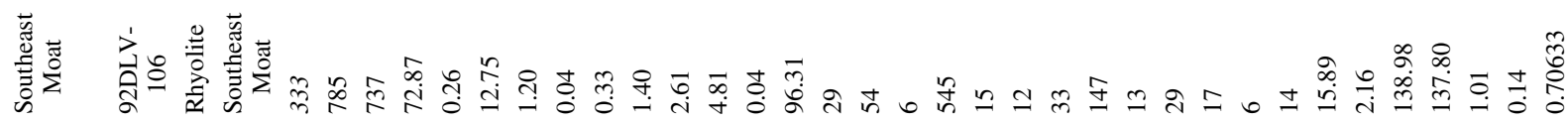

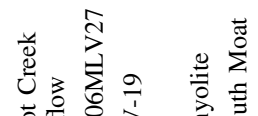

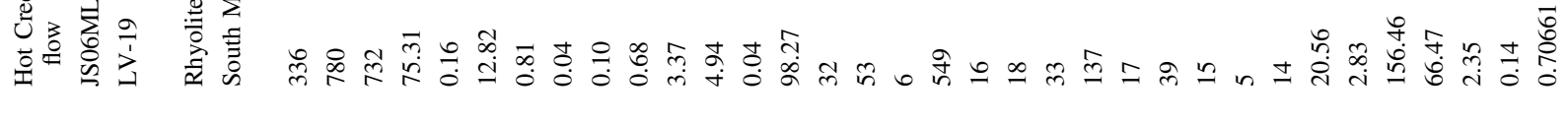
Uัँ

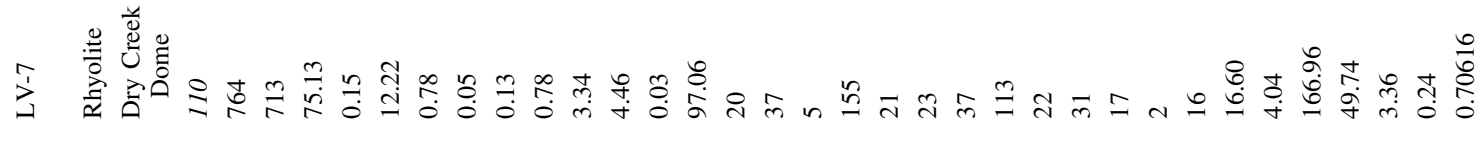

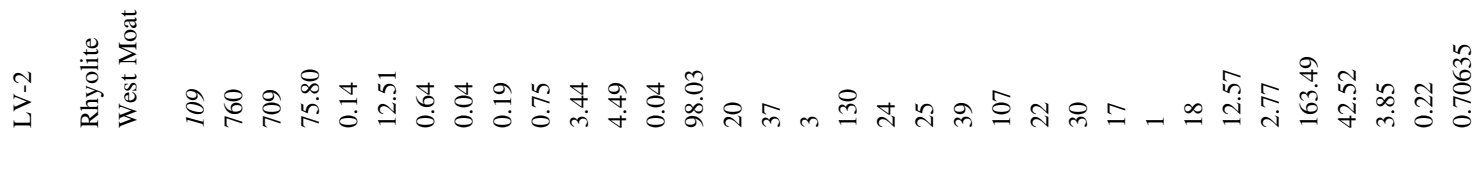

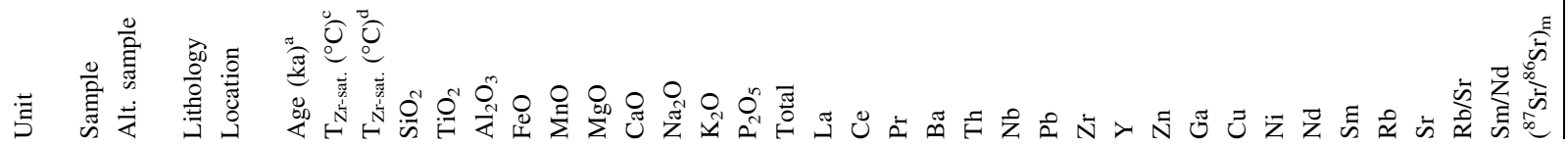




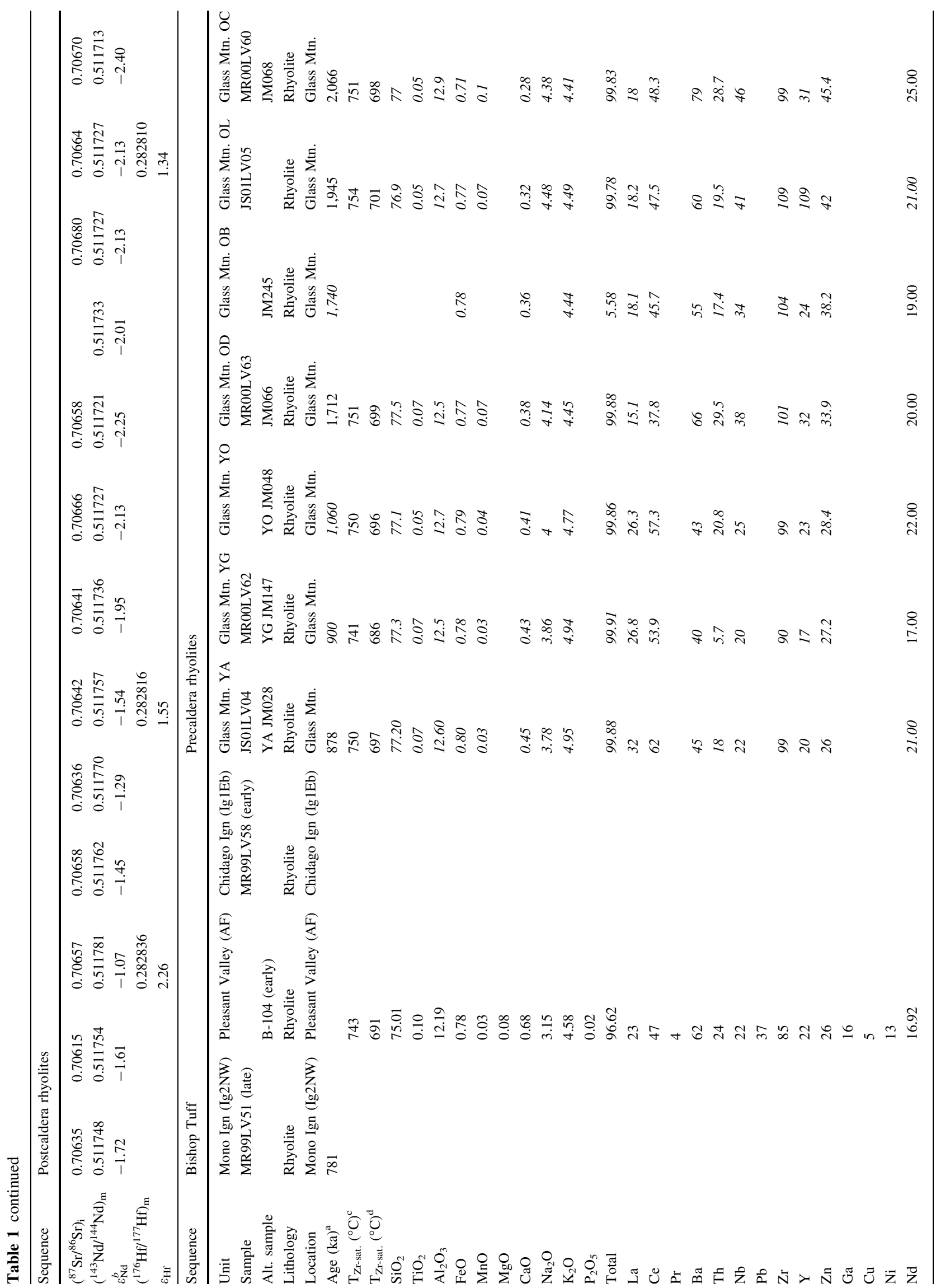




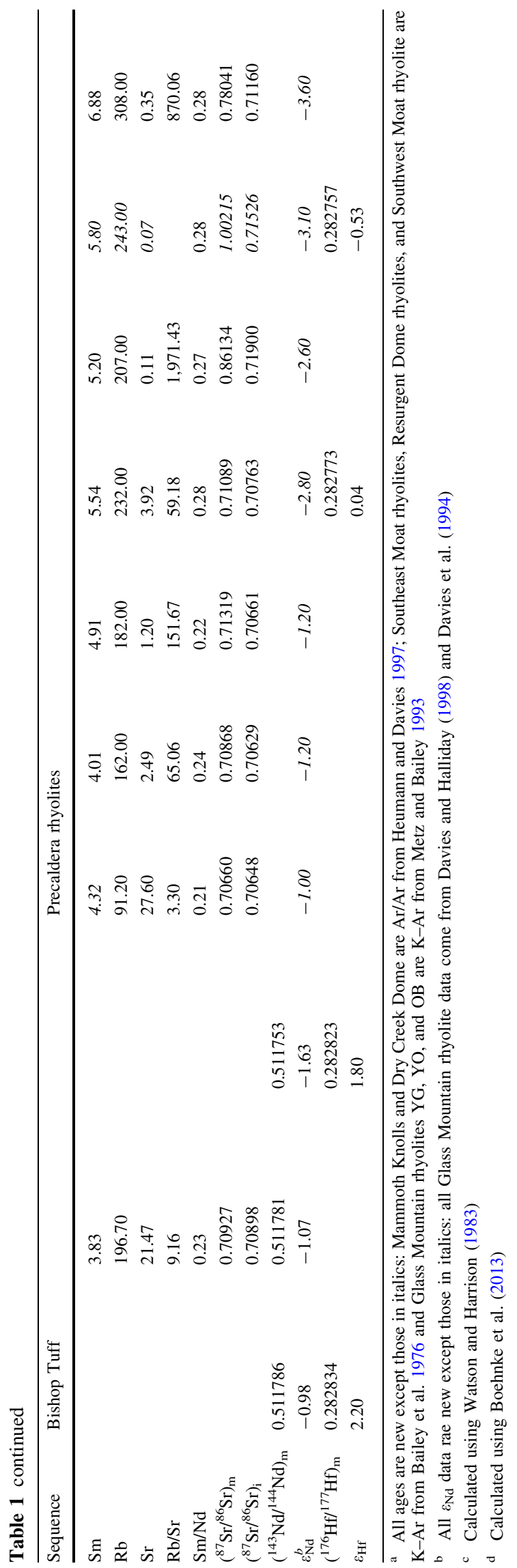

of more primitive magmas and that both types of magma were relatively transient features in the crust.

\section{Samples and Analytical Techniques}

Whole rock $\mathrm{Hf}$ and $\mathrm{Nd}$ isotopic compositions and zircon Hf isotopic compositions were measured for select postcaldera Long Valley rhyolites and Bishop Tuff pumice samples that were collected from localities of Christensen and DePaolo (1993) and following stratigraphy of Wilson and Hildreth (1997). Feldspar separates and/or host obsidian glasses were dated by ${ }^{40} \mathrm{Ar} /{ }^{39} \mathrm{Ar}$ methods for these rhyolites. New U-Pb zircon ages were determined for two postcaldera rhyolites. $\mathrm{Hf}, \mathrm{Nd}$, and $\mathrm{Sr}$ isotopic compositions were measured for a representative suite of Long Valley rhyolite samples previously studied by Christensen and DePaolo (1993), Reid and Coath (2000), Schmitt and Simon (2004), Simon and Reid (2005), and Simon et al. (2007). Zircon Hf isotopic compositions were also analyzed in several of these samples. Major and trace element abundances were measured in most of these. This study along with its predecessors (Schmitt and Simon 2004; Simon and Reid 2005; Simon et al. 2007) represents the most complete coordinated geochemical and geochronological sampling of the precaldera, Bishop Tuff, and postcaldera rhyolites from Long Valley, California (Fig. 1; Table 1). Whenever possible, we cite the ${ }^{40} \mathrm{Ar} /{ }^{39} \mathrm{Ar}$ ages measured by Simon et al. (2007), (2008b) and those reported herein, which provide the most accurate and internal consistent timeline for the volcanic history of rhyolites at Long Valley. Moreover, the U-Th- $\mathrm{Pb}$ zircon ages of Reid and Coath (2000), Reid et al. (1997), Simon and Reid (2005), and Simon et al. (2007) and those reported herein are used to address the ages that may pertain to preeruption "magma residence" timescales. The new ${ }^{40} \mathrm{Ar} /{ }^{39} \mathrm{Ar}$ ages help strengthen previously reported temporal geochemical trends (cf. Davies and Halliday 1998, reference therein, and this study) and a lower age limit with which to compare published $\mathrm{U}-\mathrm{Pb}$ zircon ages (obtained by both high spatial resolution and bulk crystal techniques). Unless stated otherwise all reported uncertainties are $1 \sigma$.

\section{Hf isotope methods for measurement of zircon and rhyolite host rocks}

To further understand existing geochemical variations (e.g., trace elements and $\mathrm{Sr}, \mathrm{Nd}$, and $\mathrm{Pb}$ isotopes) and to evaluate evidence for open-system processes within Long Valley rhyolites, Hf isotopes were measured for individual large and groups of smaller zircon grains (Fig. 2) and associated whole 
rock materials (Tables 1, 2). For Hf analysis, zircons were dissolved intact, while pumice and glass chips were powdered prior to dissolution. Prior to dissolution of zircon, adhering host glass was removed by a short ( $\sim 1 \mathrm{~min})$, dilute hydrofluoric acid ( $\sim 7 \%)$, ultrasonic bath followed by an ultrasonic bath in distilled water. Occasionally, a second ultrasonic hydrofluoric acid bath was needed. Both zircon and whole rocks were dissolved by high pressure and high temperature in Teflon ${ }^{\circledR}$ vessels. The zircon grains were processed through the low blank $\mathrm{U}-\mathrm{Pb}$ zircon dissolution procedures employed at the Berkeley Geochronology Center (Krogh 1973; Mundil et al. 2004) using sealed Krogh-style vessels. Acid digestion was carried out at $180{ }^{\circ} \mathrm{C}$ in a twostep process with both $\mathrm{HF}+\mathrm{HNO}_{3}$ (respectively 15 and $5 \mu \mathrm{l})$ and $6 \mathrm{~N} \mathrm{HCl}(25 \mu \mathrm{l})$. About $100 \mathrm{mg}$ of selected rhyolite whole rock powders was dissolved in two steps at high pressure and high temperature $\left(225\right.$ and then $\left.120^{\circ} \mathrm{C}\right)$ at the Center for Isotope Geochemistry (CIG) at the University of California Berkeley and at the Pacific Centre for Isotope and Geochemical Research (PCIGR) at the University of British Columbia. Acid digestion at CIG was carried out in a loosely caped vessel contained within a larger sealed vessel first with concentrated $\mathrm{HF}+4 \mathrm{~N} \mathrm{HNO}_{3}$ (respectively $\sim 900$ and $100 \mu \mathrm{l})$ and then $4 \mathrm{~N} \mathrm{HCl}(\sim 500 \mu \mathrm{l})$. Any fluorides formed upon drying were redissolved with a mixture of $\mathrm{HClO}_{4}$ $(\sim 150 \mu \mathrm{l})$ and $4 \mathrm{~N} \mathrm{HNO}_{3}(\sim 500 \mu \mathrm{l})$ at $120^{\circ} \mathrm{C}$ on a hot plate over night. Whole rock dissolutions at the PCIGR were performed as in Pretorius et al. (2006). Chromatographic purification of $\mathrm{Hf}$ from zircon and whole rocks was performed using procedures employed at the PCIGR originally developed by Goolaerts et al. (2004). The well-characterized zircon standard 91500 and USGS granite rock standard G-2 were processed along with the zircon and rhyolite samples. Analyses were carried out on a Nu Plasma MC-ICPMS-MS at the PCIGR. Samples were run on four separate days. Internal normalization was made using the well-characterized ULB-JMC Hf isotope standard (JMC 475), assuming a ${ }^{176} \mathrm{Hf} /{ }^{177} \mathrm{Hf}$ value of 0.282160 . Sample measurements were bracketed by analysis of JMC 475 to monitor and potentially correct for drift in instrument mass bias within and among individual sessions. Standard-sample-standard bracketing was applied if JMC $475{ }^{176} \mathrm{Hf} /{ }^{177} \mathrm{Hf}$ values drifted more than 0.000014. In most sessions, there was minimal drift so just the daily average of JMC475 analyses was used for normalization. A $1 \sigma$ precision of \pm 0.0000025 equating to a $2 \sigma$ uncertainty of \pm 0.2 epsilon $\left(\varepsilon_{\mathrm{Hf}}\right)$ units was typical for individual sample analysis, where $\varepsilon_{\mathrm{Hf}}=10^{4} \times$ $\left(\left({ }^{176} \mathrm{Hf} /{ }^{177} \mathrm{Hf}-{ }^{176} \mathrm{Hf} /{ }^{177} \mathrm{Hf}_{\mathrm{CHUR}}\right) /{ }^{176} \mathrm{Hf} /{ }^{177} \mathrm{Hf}_{\mathrm{CHUR}}\right)$. Hf purified from one of two separate fragments of zircon standard 91500 (Wiedenbeck et al. 1995) $(n=5)$ was analyzed in each session and yielded an average ${ }^{176} \mathrm{Hf} /{ }^{177} \mathrm{Hf}$ value of $0.282305 \pm 7$ (SD) that was indistinguishable from the accepted reference value of $0.282302 \pm 8$ (Goolaerts et al.

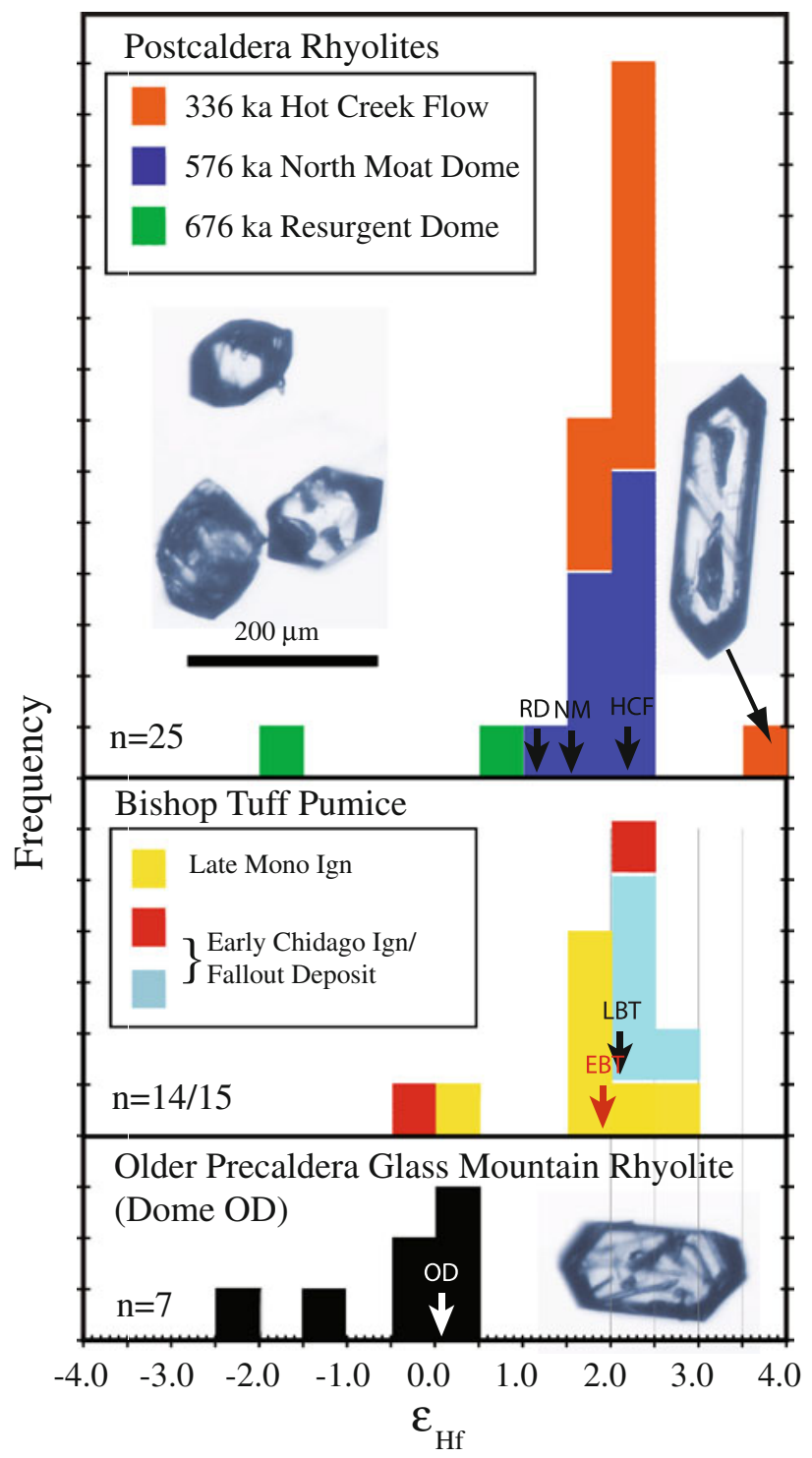

Fig. 2 Hf isotope compositions of zircon in Hot Creek flow (JS06MLV27) and North Moat (JS06MLV25 and 26) postcaldera rhyolites (top), Bishop Tuff (JS09MLV32, MR99LV58, MR99LV51) pumice fragments (middle), and Glass Mountain dome OD (MR00LV63) precaldera rhyolite (bottom). Petrographic transmitted light images of representative zircon analyzed are shown. Most analyzed zircon crystals were euhedual to subhedual and equant; mineral and glass inclusions were common. A fraction of grains in JS06MLV27 that was euhedual and elongated (example shown) yielded a high $\varepsilon_{\mathrm{Hf}}$ value of about +4 . One anomalous analysis from the Bishop Tuff yielded a low $\varepsilon_{\mathrm{Hf}}$ value of -7.5 (not shown) and is presumably a xenocryst

2004). The external reproducibility of 91500 was $\pm 0.2 \varepsilon$ units. For all calculations, a ${ }^{176} \mathrm{Hf} /{ }^{177} \mathrm{Hf}$ CHUR value of 0.282772 was used. The ${ }^{176} \mathrm{Hf} /{ }^{177} \mathrm{Hf}$ value measured for the USGS granite standard G-2 of $0.282518 \pm 2$ compares favorably to the accepted reference value of $0.282523 \pm 6$ (Weis et al. 2007). 
Table 2 Summary of zircon Hf isotope compositions

\begin{tabular}{|c|c|c|c|c|c|c|}
\hline Sample & ${ }^{176} \mathrm{Hf} /{ }^{177} \mathrm{Hf}$ & $2 \sigma$ & $\varepsilon_{\mathrm{Hf}}$ & $\pm(\varepsilon)$ & Grains $(\mathrm{N})$ & Description \\
\hline \multicolumn{7}{|c|}{ Early postcaldera rhyolites } \\
\hline \multicolumn{7}{|c|}{ 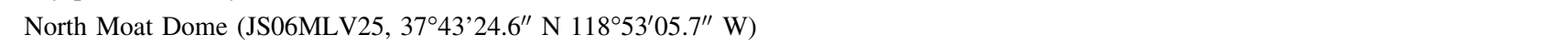 } \\
\hline JS06MLV25 WR & 0.282816 & 0.000005 & 1.55 & 0.18 & & \\
\hline JS06MLV25 g1 & 0.282819 & 0.000009 & 1.67 & 0.30 & 2 & Med-large euhedral \\
\hline JS06MLV25 g2 & 0.282827 & 0.000007 & 1.93 & 0.24 & 1 & Med-large euhedral \\
\hline JS06MLV25 g3 & 0.282806 & 0.000009 & 1.19 & 0.32 & 1 & Large euhedral \\
\hline JS06MLV25 g4 & 0.282831 & 0.000008 & 2.07 & 0.27 & 2 & Med-large euhedral \\
\hline JS06MLV25 g5 & 0.282830 & 0.000005 & 2.04 & 0.18 & 1 & Large subeuhedral \\
\hline JS06MLV25 g6 & 0.282833 & 0.000008 & 2.16 & 0.27 & 1 & Large subeuhedral \\
\hline JS06MLV25 g7 & 0.282831 & 0.000007 & 2.10 & 0.25 & 1 & Large subeuhedral \\
\hline JS06MLV25 g8 & 0.282829 & 0.000008 & 2.01 & 0.29 & 1 & Large subeuhedral \\
\hline JS06MLV25 g9 & 0.282831 & 0.000005 & 2.09 & 0.18 & 5 & Large euhedral \\
\hline JS06MLV25 g11 & 0.282821 & 0.000004 & 1.72 & 0.16 & 15 & Med-small \\
\hline JS06MLV25 g12 & 0.282825 & 0.000006 & 1.87 & 0.20 & 15 & Med-small \\
\hline \multicolumn{7}{|c|}{ 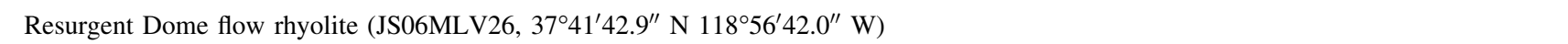 } \\
\hline JS06MLV26 WR & 0.282810 & 0.000005 & 1.34 & 0.17 & & \\
\hline JS06MLV26 g1 & 0.282725 & 0.000012 & -1.65 & 0.43 & 7 & Med \\
\hline JS06MLV26 g3 & 0.282798 & 0.000028 & 0.92 & 0.99 & 20 & Very small \\
\hline \multicolumn{7}{|c|}{ 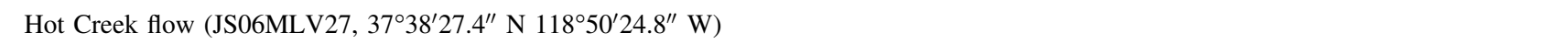 } \\
\hline JS06MLV27 WR & 0.282840 & 0.000006 & 2.40 & 0.20 & & \\
\hline JS06MLV27 WRr & 0.282832 & 0.000005 & 2.12 & 0.18 & & \\
\hline JS06MLV27 g1 & 0.282834 & 0.000008 & 2.19 & 0.28 & 6 & Med \\
\hline JS06MLV27 g2 & 0.282880 & 0.000013 & 3.81 & 0.46 & 4 & Med-large assicular \\
\hline JS06MLV27 g3 & 0.282822 & 0.000006 & 1.76 & 0.22 & 14 & Med-small clear \\
\hline JS06MLV27 g4 & 0.282833 & 0.000009 & 2.15 & 0.31 & 11 & Med more pink (some clear) \\
\hline JS06MLV27 g5 & 0.282841 & 0.000008 & 2.43 & 0.28 & 8 & Med \\
\hline JS06MLV27 g6 & 0.282838 & 0.000005 & 2.33 & 0.18 & 6 & Med \\
\hline JS06MLV27 g7 & 0.282832 & 0.000007 & 2.13 & 0.26 & 5 & Med \\
\hline JS06MLV27 g8 & 0.282823 & 0.000012 & 1.79 & 0.43 & 4 & Med all 3 morph and colors \\
\hline JS06MLV27 g9 & 0.282821 & 0.000005 & 1.75 & 0.18 & 2 & Med-large clear \\
\hline JS06MLV27 g10 & 0.282838 & 0.000009 & 2.33 & 0.30 & 13 & Med-small \\
\hline JS06MLV27 g11 & 0.282834 & 0.000010 & 2.20 & 0.35 & 6 & Med sized \\
\hline JS06MLV27 g12 & 0.282835 & 0.000014 & 2.22 & 0.50 & 4 & Med-large sized \\
\hline \multicolumn{7}{|c|}{ Bishop Tuff } \\
\hline \multicolumn{7}{|c|}{ 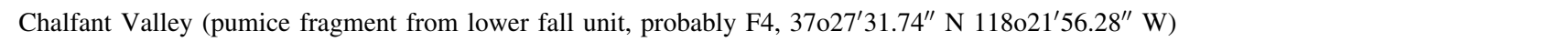 } \\
\hline JS09MLV32 g1 & 0.282841 & 0.000008 & 2.45 & 0.27 & & \\
\hline JS09MLV32 g2 & 0.282844 & 0.000007 & 2.56 & 0.26 & & \\
\hline JS09MLV32 g3 & 0.282839 & 0.000008 & 2.38 & 0.30 & & \\
\hline JS09MLV32 g4 & 0.282837 & 0.000006 & 2.31 & 0.20 & & \\
\hline JS09MLV32 g5 & 0.282836 & 0.000006 & 2.27 & 0.20 & & \\
\hline \multicolumn{7}{|c|}{ 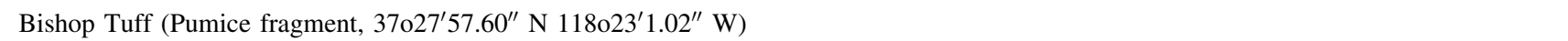 } \\
\hline MR99LV58 WR & 0.282823 & 0.000005 & 1.80 & 0.18 & & \\
\hline MR99LV58 g6 & 0.282832 & 0.000006 & 2.12 & 0.21 & & \\
\hline MR99LV58 g7 & 0.282559 & 0.000003 & -7.52 & 0.12 & & Presumably a xenocryst \\
\hline MR99LV58 g8 & 0.282767 & 0.000005 & -0.16 & 0.16 & & \\
\hline MR99LV58 g8r & 0.282772 & 0.000004 & -0.01 & 0.14 & & \\
\hline
\end{tabular}


Table 2 continued

\begin{tabular}{|c|c|c|c|c|c|c|}
\hline Sample & ${ }^{176} \mathrm{Hf} /{ }^{177} \mathrm{Hf}$ & $2 \sigma$ & $\varepsilon_{\mathrm{Hf}}$ & $\pm(\varepsilon)$ & Grains $(\mathrm{N})$ & Description \\
\hline \multicolumn{7}{|c|}{ 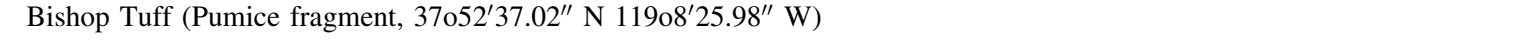 } \\
\hline MR99LV51 WR & 0.282834 & 0.000007 & 2.20 & 0.26 & & \\
\hline MR99LV51 g1 & 0.282821 & 0.000010 & 1.74 & 0.34 & 7 & Small \\
\hline MR99LV51 g2 & 0.282827 & 0.000013 & 1.94 & 0.44 & 4 & Med \\
\hline MR99LV51 g3 & 0.282821 & 0.000008 & 1.74 & 0.30 & 4 & Med \\
\hline MR99LV51 g4 & 0.282776 & 0.000009 & 0.14 & 0.32 & 3 & Med \\
\hline MR99LV51 g5 & 0.282850 & 0.000010 & 2.75 & 0.36 & 3 & Med \\
\hline MR99LV51 g6 & 0.282832 & 0.000021 & 2.11 & 0.76 & 2 & Med-large \\
\hline MR99LV51 g7 & 0.282819 & 0.000023 & 1.67 & 0.80 & 1 & Large \\
\hline MR99LV51 g7r & 0.282836 & 0.000009 & 2.25 & 0.33 & 1 & Large \\
\hline \multicolumn{7}{|c|}{ Old precaldera Glass Mountain rhyolites } \\
\hline \multicolumn{7}{|c|}{ 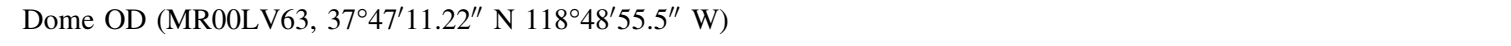 } \\
\hline MR00LV63 WR & 0.282773 & 0.000005 & 0.04 & 0.18 & & \\
\hline MR00LV63 g1 & 0.282774 & 0.000006 & 0.07 & 0.21 & 9 & Small \\
\hline MR00LV63 g2 & 0.282702 & 0.000007 & -2.47 & 0.26 & 5 & Med \\
\hline MR00LV63 g3 & 0.282784 & 0.000016 & 0.42 & 0.56 & 4 & Med \\
\hline MR00LV63 g3r & 0.282758 & 0.000009 & -0.49 & 0.30 & 4 & Med \\
\hline MR00LV63 g4 & 0.282766 & 0.000008 & -0.22 & 0.28 & 3 & Large \\
\hline MR00LV63 g5 & 0.282776 & 0.000012 & 0.13 & 0.42 & 2 & Large \\
\hline MR00LV63 g6 & 0.282744 & 0.000005 & -1.00 & 0.18 & 2 & Large \\
\hline \multicolumn{7}{|c|}{ 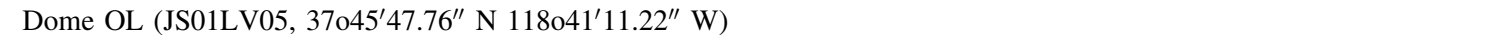 } \\
\hline JS01LV05 WR & 0.282757 & 0.000005 & -0.53 & 0.17 & & \\
\hline
\end{tabular}

\section{Nd and Sr isotope methods for measurement of Long Valley rhyolites}

A large amount of $\mathrm{Nd}$ and $\mathrm{Sr}$ isotope data for Long Valley rhyolites and their components exists (e.g., Christensen and Halliday 1996; Davies et al. 1994; Heumann and Davies 1997; Davies and Halliday 1998). For direct comparison, $\mathrm{Nd}$ isotope compositions (Table 2) were measured for the Bishop Tuff pumice samples for which Hf isotopes were collected and ${ }^{40} \mathrm{Ar} /{ }^{39} \mathrm{Ar}$ dating was performed. For completeness, $\mathrm{Nd}$ and $\mathrm{Sr}$ isotope measurements for a number of the studied rhyolites (Table 1) are also reported herein. For the $\mathrm{Nd}$ analysis, pumice and glass chips were powdered. Splits of the prepared powders of recently collected Bishop Tuff pumice samples $(\sim 100 \mathrm{mg})$ and previously measured pumice samples $(\sim 50 \mathrm{mg})$ were digested in $\mathrm{HF}^{-\mathrm{HClO}_{4}}$ mixtures on a hot plate. Standard ion chromatographic procedures were employed for element separation and $\mathrm{Nd}$ purification (e.g., DePaolo 1978). The new Nd isotope analyses were measured as atomic $\left(\mathrm{Nd}^{+}\right)$species assuming ${ }^{146} \mathrm{Nd} /{ }^{144} \mathrm{Nd}=0.72190$. The previously unpublished $\mathrm{Nd}$ isotope analyses were measured as either atomic or oxide $\left(\mathrm{NdO}^{+}\right)$species. In the latter case, it was assumed that ${ }^{162} \mathrm{NdO} /{ }^{160} \mathrm{NdO}=0.724110$. For intercomparison purposes, the sample data have been renormalized using atomic ratios following the approach described in (DePaolo
1988) in which ${ }^{148} \mathrm{Nd} /{ }^{144} \mathrm{Nd}=0.243080$. After renormalization the external reproducibly of the CIG, UC Berkeley internal standard measured between 2004-2009 is approximately 0.000013 ( $n=43,7$ run specifically for this work), which is likely representative of the previous $\mathrm{Nd}$ studies. The typical uncertainty of individual $\mathrm{Nd}$ measurements is 0.000005 or $\pm 0.1 \quad \varepsilon \quad\left(\varepsilon_{\mathrm{Nd}}\right)$, where $\varepsilon_{\mathrm{Nd}}=10^{4} \times$ $\left(\left({ }^{143} \mathrm{Nd} /{ }^{144} \mathrm{Nd}-{ }^{143} \mathrm{Nd} /{ }^{144} \mathrm{Nd}_{\mathrm{CHUR}}\right) /{ }^{143} \mathrm{Nd} /{ }^{144} \mathrm{Nd}_{\mathrm{CHUR}}\right) . \quad \mathrm{A}$ ${ }^{143} \mathrm{Nd} /{ }^{144} \mathrm{Nd}{ }_{\text {CHUR }}$ value of 0.511836 was used, based on ${ }^{146} \mathrm{Nd} /{ }^{142} \mathrm{Nd}=0.636151$. Instrumental $\mathrm{Sr}$ isotopic fractionation was corrected with an internal normalization of ${ }^{86} \mathrm{Sr} /{ }^{88} \mathrm{Sr}=0.1194$. The ${ }^{86} \mathrm{Sr} /{ }^{86} \mathrm{Sr}$ values reported herein are normalized to a SRM987 value of 0.710250 . The details for Sr isotope analyses at CIG, UC Berkeley relevant to the previously unpublished $\mathrm{Sr}$ data reported for Long Valley rhyolites can be found in Bryce et al. (2005).

\section{Systematic Hf and Nd isotopic variability recorded by Long Valley rhyolites}

Hafnium isotopic compositions of seven single $(\sim 10 \mathrm{mg})$ and 40 groups $(n=2-20)$ of size-sorted $(\leq 4.0$ to $\sim 0.3 \mathrm{mg}$ ) zircons, along with their respective whole rocks, were measured by MC-ICPMS analysis. Hafnium isotope measurements come from two Older Glass Mountain (GM) 
precaldera rhyolites, three pumice fragments from the Bishop Tuff (BT), and three postcaldera rhyolites (Table 2). All zircon grains were imaged prior to dissolution and analysis. Most were euhedual to subhedual and equant (Fig. 2). Zircons in the rhyolites record Hf isotopic compositions that broadly match the values found for their respective whole rocks, which show variable ${ }^{176} \mathrm{Hf} /{ }^{177} \mathrm{Hf}$ values ( $\sim 1-3 \varepsilon_{\mathrm{Hf}}$ unit variations, see Fig. 2$)$. In general, the Older GM rhyolites exhibit the lowest ${ }^{176} \mathrm{Hf} /{ }^{177} \mathrm{Hf}$ values in our sample suite, whereas late erupted BT (MR99LV51 and JS09MLV32) has a slightly higher ${ }^{176} \mathrm{Hf} /{ }^{177} \mathrm{Hf}$ value than the early erupted BT (MR99LV58). Postcaldera rhyolites vary in ${ }^{176} \mathrm{Hf} /{ }^{177} \mathrm{Hf}$ ratios from a slightly lower value up to nearly the same value observed for the late erupted BT (Fig. 2). Zircons found in the Older GM $\sim 1,700 \mathrm{ka}$ dome OD (MR00LV63) rhyolite display ${ }^{176} \mathrm{Hf} /{ }^{177} \mathrm{Hf}$ values equal to or lower than its inferred melt (i.e., whole rock) by up to $\sim 3 \varepsilon_{\mathrm{Hf}}$ units. Most zircons from the $\sim 780 \mathrm{ka} \mathrm{BT}$ have ${ }^{176} \mathrm{Hf} /{ }^{177} \mathrm{Hf}$ values equal to or higher than the host pumice. A few exceptions from both early and late erupted BT pumice exhibit values up to $\sim 2 \varepsilon_{\mathrm{Hf}}$ units lower. The BT also contains rare xenocrystic zircon that is much less radiogenic $\left({ }^{176} \mathrm{Hf} /{ }^{177} \mathrm{Hf}=0.28256\right)$ presumably originating from Mesozoic bedrock. Several younger ( $\sim 575$ and $\sim 335 \mathrm{ka})$ postcaldera rhyolites from the North Moat (JS06MLV25) and Hot Creek flow (JS06MLV27) contain zircons with more primitive compositions (i.e., higher $\varepsilon_{\mathrm{Hf}}$ ) than their respective whole rocks. For example, the $\sim 335$ ka Hot Creek flow postcaldera rhyolite, which has the most primitive whole rock composition studied, contains a subpopulation of elongated zircon crystals with $\varepsilon_{\mathrm{Hf}}$ values of $\sim 4$, the highest (most primitive, Fig. 2) measured in this study. We note that many of these grains had inclusions, but other relationships between morphology and $\mathrm{Hf}$ isotopic composition are absent (Fig. 2). By contrast, comparatively scarce zircon crystals from the $\sim 675$ ka Resurgent Dome flow rhyolite (JS06MLV026) fall into two zircon populations: one comprising large $(\sim 50-100 \mu \mathrm{m})$ grains with a ${ }^{176} \mathrm{Hf} /{ }^{177} \mathrm{Hf}$ composition lower (more evolved, Fig. 2) than nearly all other measurements in this study and a second population with values similar to the host whole rock composition.

Neodymium isotopic compositions of seven precaldera rhyolites, three pumice fragments from the BT, and thirteen postcaldera rhyolites (Table 1) were found to be similar to those by previous studies (e.g., Davies and Halliday 1998; Halliday et al. 1984, 1989) (see Fig. 6). Precaldera Older Glass Mountain rhyolites $(-3.6$ to -2.6 $\left.\varepsilon_{\mathrm{Nd}}\right)$ are more variable and distinct from precaldera Younger Glass Mountain rhyolites $\left(\sim-1.0 \varepsilon_{\mathrm{Nd}}\right)$. Pumice fragments from both the early (MR99LV51 \& B-104) and late (MR99LV51) erupted BT exhibit values that are more like those of the precaldera Younger rhyolites $\left(-1.6\right.$ to $\left.-1.0 \varepsilon_{\mathrm{Nd}}\right)$. Postcaldera rhyolite whole rock $\mathrm{Nd}$ isotopes fall in between the values of the two groups of precaldera rhyolites and range to maximum values that are similar to the most primitive BT samples $(\sim-1.0$ $\left.\varepsilon_{\mathrm{Nd}}\right)$. As expected, secular variations in $\mathrm{Nd}$ isotope and Hf isotope compositions of the rhyolites are correlated (Table 1).

\section{Initial $\mathrm{Sr}$ isotopic variability of Long Valley rhyolites}

The range of measured $\mathrm{Sr}$ isotopic compositions $\left({ }^{87} \mathrm{Sr} /{ }^{86} \mathrm{Sr}=0.706\right.$ to $>0.8$, Table 1$)$ found in the studied Long Valley rhyolites is extreme and similar to those found by previous studies (e.g., Davies and Halliday 1998; Halliday et al. 1984, 1989). Much, but not all of this range is produced by radiogenic ingrowth. The high $\mathrm{Rb} / \mathrm{Sr}$ compositions of Long Valley rhyolites require large age corrections (Table 1). The initial $\mathrm{Sr}$ isotope compositions $\left({ }^{87} \mathrm{Sr} /{ }^{86} \mathrm{Sr}_{\mathrm{i}}=0.70763-0.71900\right) \quad$ of studied precaldera Older Glass Mountain rhyolites are distinct and more variable than precaldera Younger Glass Mountain rhyolites $\left({ }^{87} \mathrm{Sr}^{86} \mathrm{Sr}_{\mathrm{i}} \sim 0.70650\right)$. A pumice fragment (B-104) from the early erupted $\mathrm{BT}$ exhibits a significantly higher value $\left({ }^{87} \mathrm{Sr} /{ }^{86} \mathrm{Sr}_{\mathrm{i}} \sim 0.70898\right)$ than those of the Younger precaldera rhyolites and values reported by Davies and Halliday (1998) for the BT $\left({ }^{87} \mathrm{Sr} /{ }^{86} \mathrm{Sr}_{\mathrm{i}}=0.70600-0.70698\right)$. The variability found in the postcaldera rhyolites is greatly dampened as compared to the BT and precaldera rhyolites and progressively shifts toward rocks recording the most primitive $\mathrm{Sr}$ isotope compositions $\left({ }^{87} \mathrm{Sr} /{ }^{86} \mathrm{Sr}_{\mathrm{i}} \sim 0.70600\right)$ found at Long Valley.

\section{${ }^{40} \mathrm{Ar} /{ }^{39} \mathrm{Ar}$ dating of obsidian and feldspar}

Most ${ }^{40} \mathrm{Ar} /{ }^{39} \mathrm{Ar}$ ages were obtain by laser heated individual or multi-grain feldspar analysis. In several cases, obsidian host glass was also dated. Only aphyric obsidian was dated for the sample (JS06MLV23) collected from the postcaldera North Moat flow rhyolite on the eastern flank of Lookout Mountain (Fig. 1). Feldspars were separated from crystal-poor obsidian, perlitic, and pumiceous glasses, concentrated by heavy liquid and magnetic separation techniques, and cleaned by short ultrasonic baths of dilute hydrofluoric acid followed by distilled water. Alkali feldspars were distinguished from plagioclase using immersion oils and petrographic methods, and each grain was then selected by hand for analysis. Obsidian samples were crushed to produce fragments of black glass, free of phenocrysts, and cleaned in distilled water with an ultrasonic bath. Two irradiations were used, the same ones used by Simon 
et al. (2009). The rhyolite materials, along with 91 Alder Creek feldspars $(1,193 \pm 1 \mathrm{ka}$; Nomade et al. 2005), used to monitor the neutron fluence, were irradiated at the Oregon State University TRIGA reactor in the Cdlined CLICIT facility for $30 \mathrm{~min}$ within a series of stacked aluminum disks, permitting precise monitoring of both vertical and lateral (negligible) flux gradients (see supplementary Appendix for specifics). Total fusion and step-heating feldspar and glass analyses were performed. Individual and multi-grain feldspar aliquots and glasses were analyzed by laser step heating following procedures described previously (Nomade et al. 2005; and references therein). The ${ }^{40} \mathrm{Ar} /{ }^{39} \mathrm{Ar}$ results are summarized in Table 3. Grain size fractions, specific materials dated, and complete analytical details can be found in the supplementary Appendix. Age spectra derived from laser step heating of samples from previously dated domes show that excess ${ }^{40} \mathrm{Ar}$ contamination likely biased some $\mathrm{K}-\mathrm{Ar}$ results. However, ${ }^{40} \mathrm{Ar} /{ }^{39} \mathrm{Ar}$ analyses of the studied rhyolites with disturbed model ages (i.e., assuming atmospheric initial Ar), but well-defined $\mathrm{Ar}$ isochrons are considered to provide accurate eruption ages (Fig. 3). ${ }^{40} \mathrm{Ar} /{ }^{39} \mathrm{Ar}$ ages are calibrated per Renne et al. (2011), which intrinsically provides consistency with the ${ }^{238} \mathrm{U}$ decay constant and thus facilitates comparison with $\mathrm{U}_{-}$ $\mathrm{Th}-\mathrm{Pb}$ ages.

\section{${ }^{40} \mathrm{Ar} /{ }^{39} \mathrm{Ar}$ eruption ages of Long Valley rhyolites}

New ${ }^{40} \mathrm{Ar} /{ }^{39} \mathrm{Ar}$ ages were determined for nine rhyolites erupted from the Long Valley volcanic field (Table 3; Fig. 3). This work complements the ${ }^{40} \mathrm{Ar} /{ }^{\beta 9} \mathrm{Ar}$ dating of rhyolites reported by Davies et al. (1994), Heumann et al. (2002), Miller (1985), Simon et al. (2007), and Simon et al. (2008b). We used the same mass spectrometer at the Berkeley Geochronology Center, methods, and irradiations and carried out the experiments at essentially the same time as those published previously by Simon et al. (2007, 2008b). Previously determined ages for precaldera rhyolite domes OC (MR00LV60 and 61), OL (JS01LV05), OD (MR00LV63), YG (K-Ar age of Metz and Bailey (1993), and YA (JS01LV04); postcaldera rhyolite Deer Mountain; and Inyo Mono rhyolite South Deadman Dome have been included in Table 3 for completeness. All reported ages have been recalculated to the calibration of Renne et al. (2011). When possible and statistically plausible, results from multiple laser heating experiments were combined to define a more precise age for a given extrusion (see supplementary Appendix). The oldest rhyolite dated in the present study was the caldera-related Bishop Tuff. Inverse ${ }^{40} \mathrm{Ar} /{ }^{39} \mathrm{Ar}$ isochron ages defined by total fusion analysis of $n=24$ and 26 individual sanidine grains for pumice fragments B77 (Hildreth 1977) and MR99LV51 (Simon and Reid
2005) yielded eruption ages of $780 \pm 5 \mathrm{ka}\left({ }^{40} \mathrm{Ar} /{ }^{36} \mathrm{Ar}=\right.$ $295 \pm 1)$ and $781 \pm 6 \mathrm{ka}\left({ }^{40} \mathrm{Ar} /{ }^{36} \mathrm{Ar}=294 \pm 1\right)$, respectively. A combined inverse isochron defined by sanidine from both pumice fragments yielded an age of $781 \pm 5 \mathrm{ka}$ $\left({ }^{40} \mathrm{Ar} /{ }^{36} \mathrm{Ar}=294 \pm 1\right)$. The combined weighted mean of the individual grains $(n=50)$ yielded a more precise age of $780 \pm 2 \mathrm{ka}$. This age is indistinguishable from that of SarnaWojcicki et al. (2000) when the latter is recalculated per Renne et al. (2011), but significantly older than that of $767.4 \pm 0.2$ ka cited by Rivera et al. (2011). The oldest dated "Early" postcaldera rhyolites from the West Resurgent Dome (JS06MLV29 and 30) yielded ages of approximately $700 \mathrm{ka}$. Inverse isochrons defined by laser heating of two mineral separates of plagioclase from JS06MLV29 yielded consistent ages of $696 \pm 40 \mathrm{ka}\left({ }^{40} \mathrm{Ar} /{ }^{36} \mathrm{Ar}=309 \pm 6\right)$ and $706 \pm$ $25 \mathrm{ka}\left({ }^{40} \mathrm{Ar} /{ }^{36} \mathrm{Ar}=302 \pm 4\right)$. A third mineral separate yielded discordant $464 \pm 50 \mathrm{ka}\left({ }^{40} \mathrm{Ar} /{ }^{36} \mathrm{Ar}=340 \pm 10\right)$ isochron, $529 \pm 35 \mathrm{ka}$ plateau, and $759 \pm 120 \mathrm{ka}$ integrated ages; these anomalous results may reflect laboratory contamination and are excluded from further consideration. A similar inverse isochron age for a plagioclase mineral separate from JS06MLV30 was determined to be $696 \pm 45 \mathrm{ka}$ $\left({ }^{40} \mathrm{Ar} /{ }^{36} \mathrm{Ar}=303 \pm 4\right)$ within error of the $666 \pm 15 \mathrm{ka}$ plateau age for the associated host glass. Laser step heating of obsidian (JS06MLV23) from Lookout Mountain, a North Moat rhyolite, yielded an age of $684 \pm 9 \mathrm{ka}$ $\left({ }^{40} \mathrm{Ar} /{ }^{36} \mathrm{Ar}=297 \pm 3\right)$. This age is within error of the $673 \pm 14 \mathrm{ka} \mathrm{K}-\mathrm{Ar}$ age of Bailey et al. (1976) for aphyric rhyolite (72G010) sampled from the same flow. An inverse isochron age defined by laser heating of a plagioclase mineral separate from a Resurgent Dome rhyolite (JS06MLV26) yielded a similar age of $676 \pm 15 \mathrm{ka}\left({ }^{40} \mathrm{Ar} /{ }^{36} \mathrm{Ar}=301 \pm 4\right)$. This age appears to be older than the $634 \pm 13 \mathrm{ka} \mathrm{K}-\mathrm{Ar}$ age of Bailey et al. (1976) for pyroxene rhyolite (72G014) sampled from the same dome. A finer sized mineral separate of plagioclase yielded a consistent $686 \pm 20$ ka plateau age. A combined inverse isochron of both plagioclase mineral separates yielded an age of $676 \pm 15 \mathrm{ka}\left({ }^{40} \mathrm{Ar} /{ }^{36} \mathrm{Ar}=294 \pm 3\right)$. An inverse isochron aged defined by laser heating of a plagioclase mineral separate from the South Resurgent Dome rhyolite (JS06MLV28) yielded an age of $656 \pm 30 \mathrm{ka}$ $\left({ }^{40} \mathrm{Ar} /{ }^{36} \mathrm{Ar}=311 \pm 3\right)$. This age is similar to the $675 \pm 16 \mathrm{ka} \mathrm{K}-\mathrm{Ar}$ age of Bailey et al. (1976) for aphyric rhyolite (72G001) sampled from the same flow. Two North Moat rhyolites (JS06MLV24 and 25) yielded distinctly younger ages of approximately $576 \mathrm{ka}$. Yet, both moat rhyolites are found to be significantly older than the $468 \pm 11$ and $509 \pm 11 \mathrm{ka} \mathrm{K}-\mathrm{Ar}$ ages reported by Bailey et al. (1976) for the corresponding hornblende-biotite rhyolites (72G011 and 72G012). Inverse isochron ages obtained for three different mineral separates of sanidine from JS06MLV24 yielded ages of $571 \pm 10 \mathrm{ka} \quad\left({ }^{40} \mathrm{Ar}{ }^{36} \mathrm{Ar}=295 \pm 10\right)$, $585 \pm 10 \mathrm{ka} \quad\left({ }^{40} \mathrm{Ar} /{ }^{36} \mathrm{Ar}=270 \pm 20\right), \quad$ and $\quad 579 \pm 9 \mathrm{ka}$ 


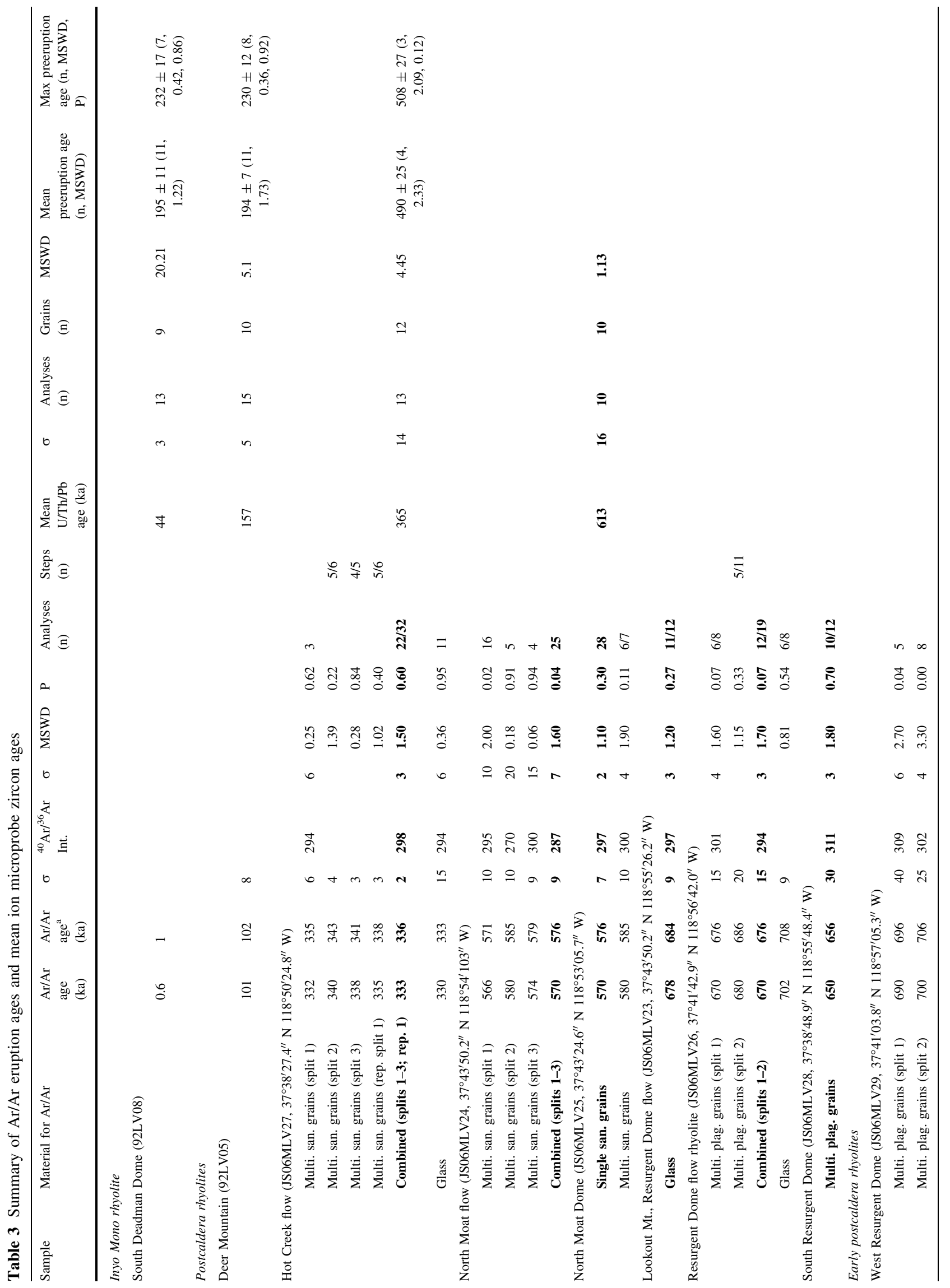




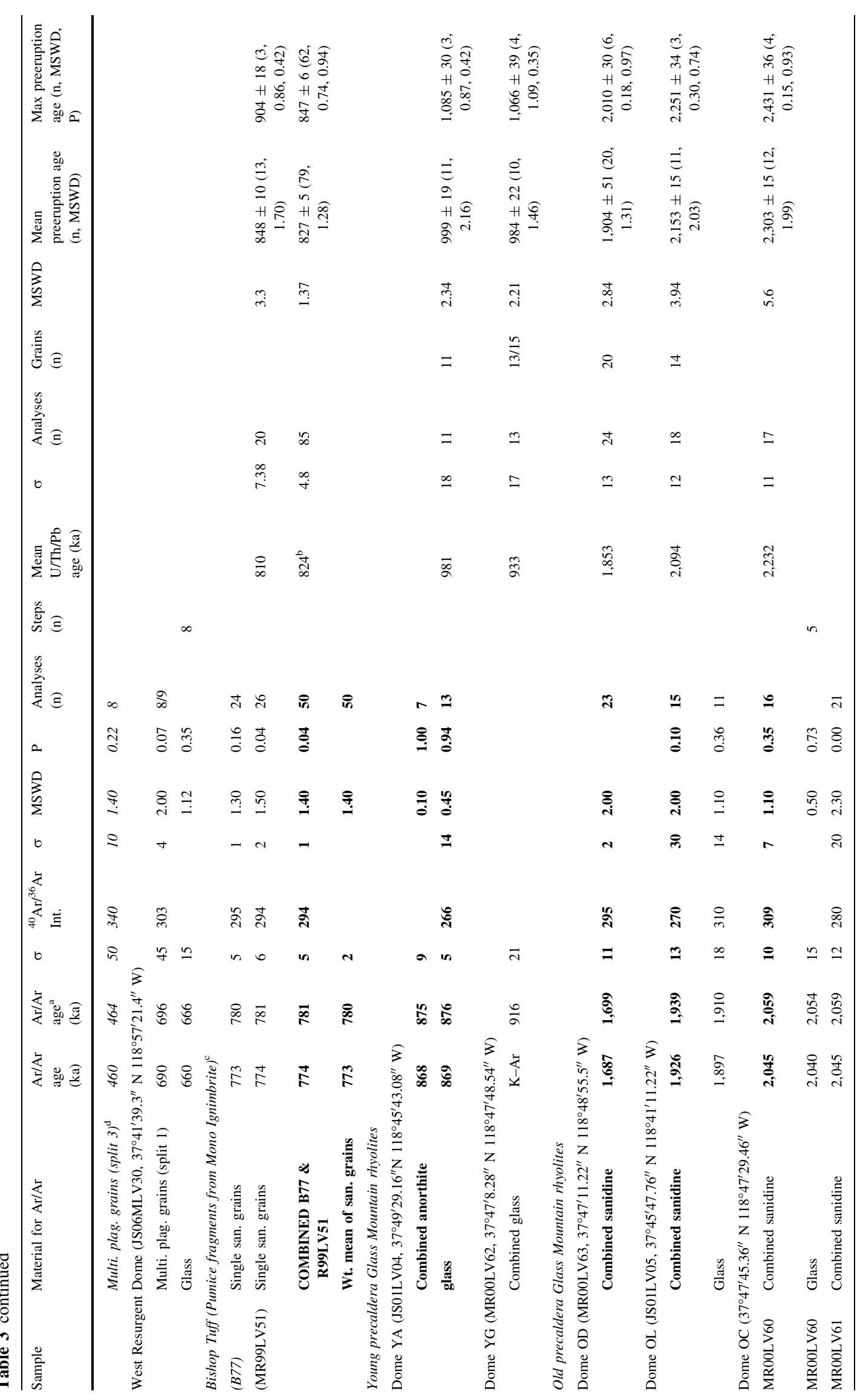


$\left({ }^{40} \mathrm{Ar} /{ }^{36} \mathrm{Ar}=300 \pm 15\right)$. The combined inverse isochron yielded the age of $576 \pm 9 \mathrm{ka}\left({ }^{40} \mathrm{Ar} /{ }^{36} \mathrm{Ar}=287 \pm 7\right)$. An inverse isochron age defined by total fusion analysis of individual sanidine grains $(n=28)$ from JS06MLV25 yielded an age of $576 \pm 7 \mathrm{ka}\left({ }^{40} \mathrm{Ar} /{ }^{36} \mathrm{Ar}=297 \pm 2\right)$. The companion inverse isochron age defined by step-heating analysis of a mineral separate of sanidine yielded an age of $585 \pm 10 \mathrm{ka}$ $\left({ }^{40} \mathrm{Ar} /{ }^{36} \mathrm{Ar}=300 \pm 4\right)$. The youngest rhyolite dated was the Hot Creek flow (JS06MLV27). An inverse isochron defined by one of three distinct mineral separates of sanidine yielded the age of $335 \pm 6 \mathrm{ka}\left({ }^{40} \mathrm{Ar} r{ }^{36} \mathrm{Ar}=294 \pm 6\right)$. Plateau ages for two additional sanidine mineral separates and a duplicate split of the first mineral separate were $343 \pm 4,341 \pm 3$, and $338 \pm 3 \mathrm{ka}$, respectively. A combined inverse isochron of all of the results yielded the age of $336 \pm 2 \mathrm{ka}$ $\left({ }^{40} \mathrm{Ar} /{ }^{36} \mathrm{Ar}=298 \pm 3\right)$, which is within error of an inverse isochron age for the host glass of $333 \pm 15 \mathrm{ka}\left({ }^{40} \mathrm{Ar} /{ }^{36} \mathrm{Ar}=\right.$ $294 \pm 6)$.

\section{U-Th-Pb dating of zircon by ion microprobe}

Zircon grains were separated by heavy liquid techniques from crushed obsidian samples. U-Th- $\mathrm{Pb}$ dating was performed on individual zircon crystals using the UCLA CAMECA ims 1,270 secondary ion mass spectrometer (ion microprobe), similar to methods performed previously (Simon and Reid 2005). A <20-50 nA mass-filtered ${ }^{16} \mathrm{O}^{-}$-beam was focused into a $\sim 25-30$ um oval spot. Secondary ions were accelerated at $10 \mathrm{keV}$ with an energy bandpass of $50 \mathrm{eV}$ and analyzed at a mass resolution of $>4,800$. The relative sensitivities for ${ }^{238} \mathrm{UO}$ and ${ }^{232} \mathrm{ThO}$ were calibrated by measuring the radiogenic ${ }^{206} \mathrm{~Pb} /{ }^{208} \mathrm{~Pb}$ ratio of concordant reference zircons AS-3 and 91500 (Paces and Miller 1993; Wiedenbeck et al. 1995). Individual $\mathrm{U}-\mathrm{Pb}$ ages were ${ }^{207} \mathrm{~Pb}$-corrected for common $\mathrm{Pb}$ using a measured whole rock initial common ${ }^{207} \mathrm{~Pb} /{ }^{206} \mathrm{~Pb}$ ratio of 0.818 , typical of Long Valley rhyolites (Simon et al. 2007). The common lead composition is likely to be largely extrinsic, i.e., resulting from beam overlap with inclusions trapped within the host zircon, but could also be partly due to surficial contamination of the mounts by anthropogenic $\mathrm{Pb}$, which for southern California has a similar composition (Sañudo-Wilhelmy and Flegal 1994). The ${ }^{207} \mathrm{~Pb}$-corrected ages are also adjusted for initial U-Th disequilibrium due to the deficit in radiogenic ${ }^{206} \mathrm{~Pb}$ originating from the initial deficit in ${ }^{230} \mathrm{Th}$ relative to ${ }^{238} \mathrm{U}$ following Schärer (1984). The magnitude of this deficit can be estimated by comparing the $\mathrm{Th} / \mathrm{U}$ ratios in zircon to those of the host magmas (i.e., glass). The absolute effect of this correction (typically adding 80-90 ka; Simon et al. 2008b) is accurate to $\sim 10 \mathrm{ka}$, allowing for 

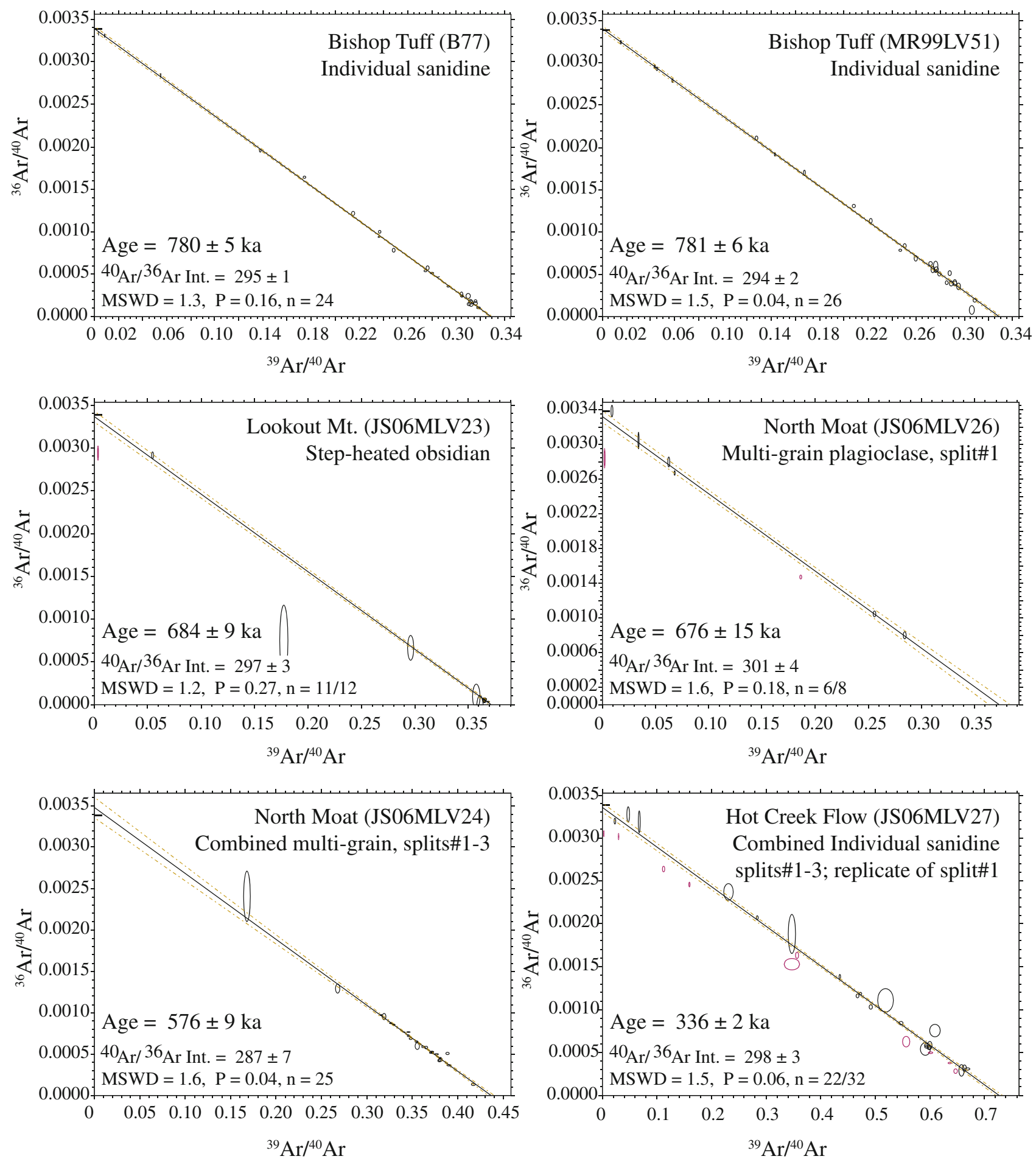

Fig. $3{ }^{40} \mathrm{Ar} /{ }^{39} \mathrm{Ar}$ ages for feldspar and glass of the Bishop Tuff and selected postcaldera rhyolites. Sample names labeled in plots and their locations can be found in Fig. 1, except Bishop Tuff sample B77 that originated from Hildreth (1977). Inverse isochrons reflect combined total fusion and step-heating data from individual and

the range of whole rock $\mathrm{Th} / \mathrm{U}$ ratios observed at Long Valley (e.g., Metz and Mahood 1991). Given the level of precision in which Pleistocene zircon ages and ${ }^{40} \mathrm{Ar} /{ }^{39} \mathrm{Ar}$

multiple feldspar grain or obsidian analysis, as indicated. Error ellipses are $1 \sigma$. The thin-lined ( $r e d$ ) data reflect those likely to have excess $\mathrm{Ar}_{*}$ contamination and have been excluded from calculated age. See Table 3 and the complete data set found in supplementary Appendix

ages are now being performed, this uncertainty can be important and should not be ignored (cf. Crowley et al. 2007, see possible implications below). 


\section{U-Pb zircon age constraints on crystallization} of postcaldera North Moat and Hot Creek flow rhyolites

Zircon ages reported here (Fig. 4) for the 336 ka Hot Creek flow (JS06MLV27) and the $576 \mathrm{ka}$ North Moat (JS06MLV25) postcaldera rhyolites extend the results for zircon age populations determined previously for Long Valley rhyolites (Crowley et al. 2007; Reid and Coath 2000; Simon and Reid 2005; Simon et al. 2007). Although the apparent $365 \pm 14 \mathrm{ka}$ age for the zircon population $(n=13)$ found in the Hot Creek flow rhyolite is within error of its ${ }^{40} \mathrm{Ar} /{ }^{39} \mathrm{Ar}$ eruption age, the weighted mean yields a mean square of the weighted deviates (MSWD) $=4.45$, exceeding that expected for a single age population. Zircon crystallization appears to have been protracted, with some growth possibly predating eruption by as much as $\sim 115 \mathrm{ka}$. In contrast, the $613 \pm 16 \mathrm{ka}$ weighted mean age of zircon $(n=10)$ contained in the North Moat rhyolite yields an MSWD of 1.13 implying that crystallization largely occurred at the time of, or just preceding, eruption. The weighted mean zircon crystallization ages and associated values for the MSWD of the North Moat and Hot Creek flow zircon populations are summarized along side their respective ${ }^{40} \mathrm{Ar} /{ }^{39} \mathrm{Ar}$ eruption ages in Table 3; individual ages, $\mathrm{U}$ concentrations, and $\mathrm{Th} / \mathrm{U}$ ratios for zircons analyzed in this study can be found in Table 4. Likewise, previously reported zircon ages of Reid et al. (1997), Simon and Reid (2005), and Simon et al. (2007) along with the new ${ }^{40} \mathrm{Ar} /{ }^{39} \mathrm{Ar}$ ages are included in Table 3. Estimates for model preeruption ages and for the duration of crystallization for all of the extrusions dated are given in Table 3, following the approach of Simon and Reid (2005). Because the MSWD of small data sets that are normally distributed around a single mean value may deviate from the expected value of unity, we also provide the MSWD values at the upper $95 \%$ confidence interval on a single age distribution as defined by the degrees of freedom for each rhyolite.

Uranium concentrations of Hot Creek flow $(\sim 250-850 \mathrm{ppm})$ and North Moat ( 200-2,700 ppm) zircons are typically lower than those found in the precaldera rhyolites and early erupted BT (that are mostly $\sim 2,000$ to $>10,000 \mathrm{ppm}$ ), but more similar to those in the late erupted BT (Simon and Reid 2005; Simon et al. 2007). Moreover, the range of $\mathrm{Th} / \mathrm{U}$ values recorded by zircon of these postcaldera rhyolites is greater than all but one of the precaldera rhyolites (dome OD) and similar to that observed for the BT (Fig. 5).

\section{Major and trace element compositions of Long Valley rhyolites}

The major and trace element abundances of some studied Long Valley rhyolites were determined by XRF at UC

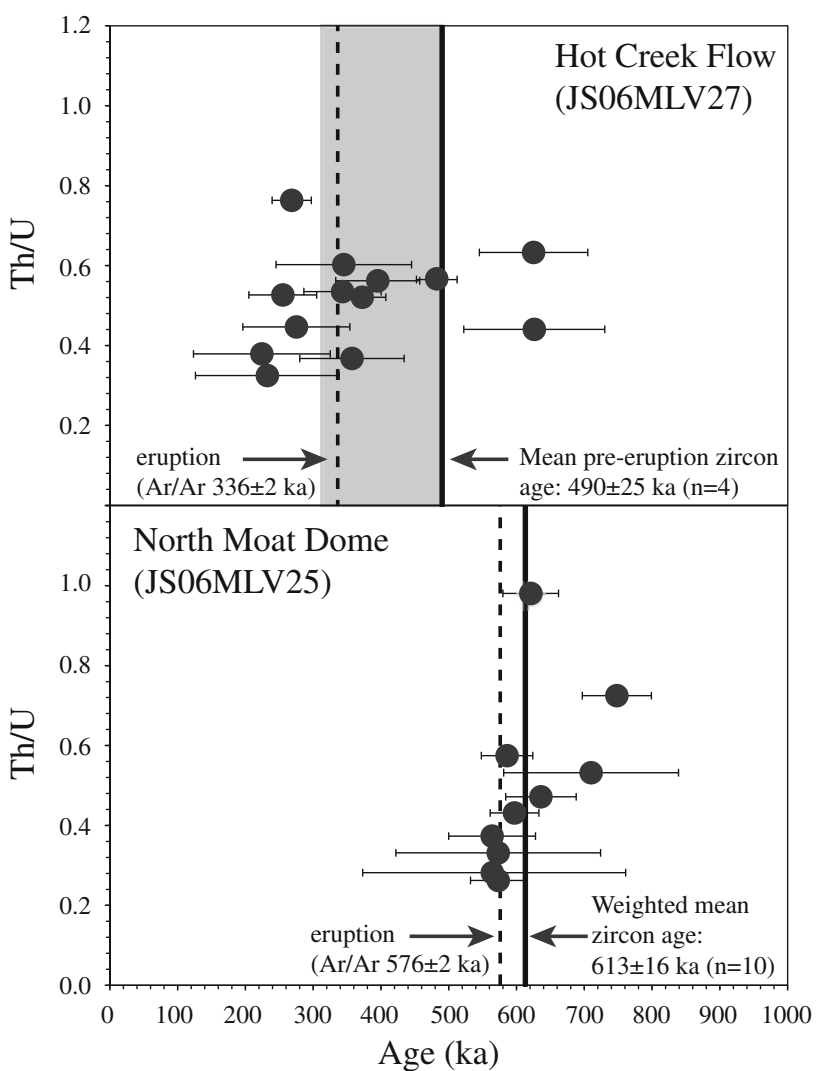

Fig. 4 Comparison of the distribution of $\mathrm{U}-\mathrm{Th}-\mathrm{Pb}$ zircon crystallization ages to Ar/Ar eruption ages for Hot Creek flow and North Moat postcaldera rhyolites. Circles indicate individual zircon measurements, solid line indicate the mean preeruption age (Hot Creek flow) or weighted mean age (North Moat), and shaded vertical band implies duration of zircon crystallization based on pooling older and younger ages, respectively (Table 1), for the Hot Creek flow rhyolite (see text for details). For each mean age, $n$ gives the number of analyses. Dashed vertical lines show Ar/Ar eruption ages. All uncertainties are $1 \sigma$

Berkeley. Rubidium, $\mathrm{Sr}, \mathrm{Sm}$, and $\mathrm{Nd}$ abundances were determined by ID-TIMS at CIG, UC Berkeley. The XRF data (Table 1) were collected following established methods described in Wallace and Carmichael (1989). The compositions of Long Valley rhyolites have been reported previously (e.g., Heumann and Davies 1997; Hildreth and Wilson 2007; Metz and Mahood 1991). The results reported here are similar to those published previously, but come from samples and specific localities studied herein. All of the precaldera lavas are highly evolved high-silica rhyolites with 77-77.4 wt\% $\mathrm{SiO}_{2}$ (e.g., Metz and Mahood 1985), typically about as evolved as the most evolved pumice from the Bishop Tuff (mainly 74-77.7 wt\% $\mathrm{SiO}_{2}$, Hildreth and Wilson 2007) and more evolved than many of the postcaldera rhyolites ( $\sim 72$ to $\sim 76 \mathrm{wt} \% \mathrm{SiO}_{2}$, Heumann and Davies 1997). Compositions of precaldera rhyolites are also less variable than those found in the Bishop Tuff and postcaldera rhyolites 
Table 4 Results of $\mathrm{U} / \mathrm{Th} / \mathrm{Pb}$ ion microprobe analyses of zircon from selected postcaldera Long Valley rhyolites

\begin{tabular}{|c|c|c|c|c|c|c|}
\hline Spot number & ${ }^{206} \mathrm{~Pb} /{ }^{238} \mathrm{U}\left(\mathrm{x} 10^{4}\right)^{\mathrm{a}}$ & $\chi^{\mathrm{b}}$ & Age $(\mathrm{ka})^{\mathrm{c}}$ & $\sigma_{\mathrm{m}}$ & $\mathrm{Th} / \mathrm{U}$ & $\mathrm{U}(\mathrm{ppm})^{\mathrm{d}}$ \\
\hline \multicolumn{7}{|c|}{ North Moat rhyolite $(J S 06 M L V 25)^{\mathrm{e}}$} \\
\hline UCLA SIMS MLV25g1 & 1.28 & 56.4 & 564 & 64 & 0.37 & 486 \\
\hline UCLA SIMS MLV25g3 & 3.29 & 22.0 & 567 & 194 & 0.28 & 202 \\
\hline UCLA SIMS MLV25g2 & 1.14 & 63.9 & 573 & 41 & 0.26 & 598 \\
\hline UCLA SIMS MLV25g9s1 & 5.85 & 12.6 & 573 & 151 & 0.33 & 356 \\
\hline UCLA SIMS MLV25g8 & 1.04 & 73.8 & 586 & 38 & 0.57 & 583 \\
\hline UCLA SIMS MLV25g4 & 1.15 & 67.7 & 597 & 36 & 0.43 & 649 \\
\hline UCLA SIMS MLV25g5 & 2.47 & 34.0 & 621 & 41 & 0.98 & 2,718 \\
\hline UCLA SIMS MLV25g9s2 & 1.10 & 75.9 & 636 & 52 & 0.47 & 615 \\
\hline UCLA SIMS MLV25g7 & 11.20 & 8.5 & 710 & 129 & 0.53 & 473 \\
\hline UCLA SIMS MLV25g6 & 2.16 & 47.4 & 748 & 51 & 0.72 & 1,024 \\
\hline \multicolumn{7}{|c|}{ Hot Creek flow rhyolite $(J S 06 M L V 27)^{\mathrm{e}}$} \\
\hline UCLA SIMS MLV27g2 & 0.81 & 24.1 & 224 & 101 & 0.38 & 206 \\
\hline UCLA SIMS MLV27g11 & 0.69 & 29.8 & 232 & 106 & 0.32 & 251 \\
\hline UCLA SIMS MLV27g8 & 0.71 & 35 & 255 & 50 & 0.53 & 406 \\
\hline UCLA SIMS MLV27g4 & 0.60 & 46.6 & 268 & 29 & 0.76 & 671 \\
\hline UCLA SIMS MLV27g5 & 1.90 & 14.5 & 275 & 79 & 0.45 & 447 \\
\hline UCLA SIMS MLV27g13 & 1.03 & 37.3 & 343 & 57 & 0.53 & 667 \\
\hline UCLA SIMS MLV27g1 & 1.18 & 33.2 & 345 & 100 & 0.60 & 201 \\
\hline UCLA SIMS MLV27g9 & 1.66 & 24.1 & 357 & 77 & 0.37 & 337 \\
\hline UCLA SIMS MLV27g14 & 0.65 & 66.4 & 372 & 35 & 0.52 & 591 \\
\hline UCLA SIMS MLV27g3 & 0.82 & 57.3 & 395 & 62 & 0.56 & 485 \\
\hline UCLA SIMS MLV27g12 & 0.91 & 66.3 & 482 & 30 & 0.56 & 837 \\
\hline UCLA SIMS MLV27g7 & 1.61 & 51.3 & 625 & 80 & 0.63 & 270 \\
\hline UCLA SIMS MLV27g6 & 2.90 & 28.3 & 626 & 104 & 0.44 & 479 \\
\hline
\end{tabular}

a Raw data

b Fraction of radiogenic ${ }^{206} \mathrm{~Pb}$ based on common ${ }^{207} \mathrm{~Pb} /{ }^{206} \mathrm{~Pb}$ correction

c Ages corrected for initial ${ }^{206} \mathrm{~Pb}$ and ${ }^{238} \mathrm{U}$-series disequilibrium

d $\mathrm{U}$ concentrations are $\sim 5 \%(\sigma)$ based on comparison to measurement of zircon standard 91500

e Analyses are identified by grain (g\#) and spot (s\#)

(see Fig. 8). A detailed account of the major and trace element compositions of Long Valley rhyolites is beyond the scope of this contribution. Here, we are primarily focused on chemical differences, in particular with respect to estimates of magma residence time, with the goal to understand the presumed genetic relationship(s) among Long Valley rhyolites. Both long-term trends and short-term fluctuations are present as can be seen in the representative examples in Figs. 5, 8, and 9, which show temporal variation among $\mathrm{Th} / \mathrm{U}$ ratios, $\mathrm{CaO} \mathrm{wt} \%$, and in $\mathrm{La} / \mathrm{Nd}$ ratios, respectively.

\section{Discussion}

Previous work on the Long Valley Caldera system

Most studies of Long Valley rhyolites ultimately seek to understand the processes producing the cataclysmic Bishop
Tuff magma(s). Below we discuss evidence for multiple compositionally distinct pre-Bishop magmas, whereby crystals from only the youngest of these magmas were incorporated into the caldera-related Bishop Tuff. Additionally, we discuss how the ages and compositions of postBishop magmas differed from those of the pre-Bishop and Bishop magma reservoirs and how the volcanic productivity at Long Valley appears to be related to changes in the amount of mantle-derived recharge to the system. The processes that have led to heterogeneity among Long Valley rhyolites, and in particular the Bishop Tuff, have been studied for over 30 years (e.g., Hildreth 1977; Hildreth and Wilson 2007). Melt compositions investigated by analysis of melt inclusions in phenocrysts and the phenocrysts themselves have provided important insights about the diversity of preeruptive magma bodies, in particular those of the Bishop Tuff (e.g., Anderson et al. 2000; Halliday et al. 1984; Hervig and Nelia 1992; Roberge et al. 
Fig. $5 \mathrm{Th} / \mathrm{U}$ melt evolution recorded by studied Long Valley rhyolites (top) and zircon (bottom). Relatively narrow times where the range of $\mathrm{Th} / \mathrm{U}$ compositions observed in zircon is large may indicate that these magmas evolved rather quickly (see text). Enlarged time interval shows Bishop Tuff zircon from Crowley et al. (2007) that postdate eruption and probably reflect an oversimplified U-series decay correction (see text)

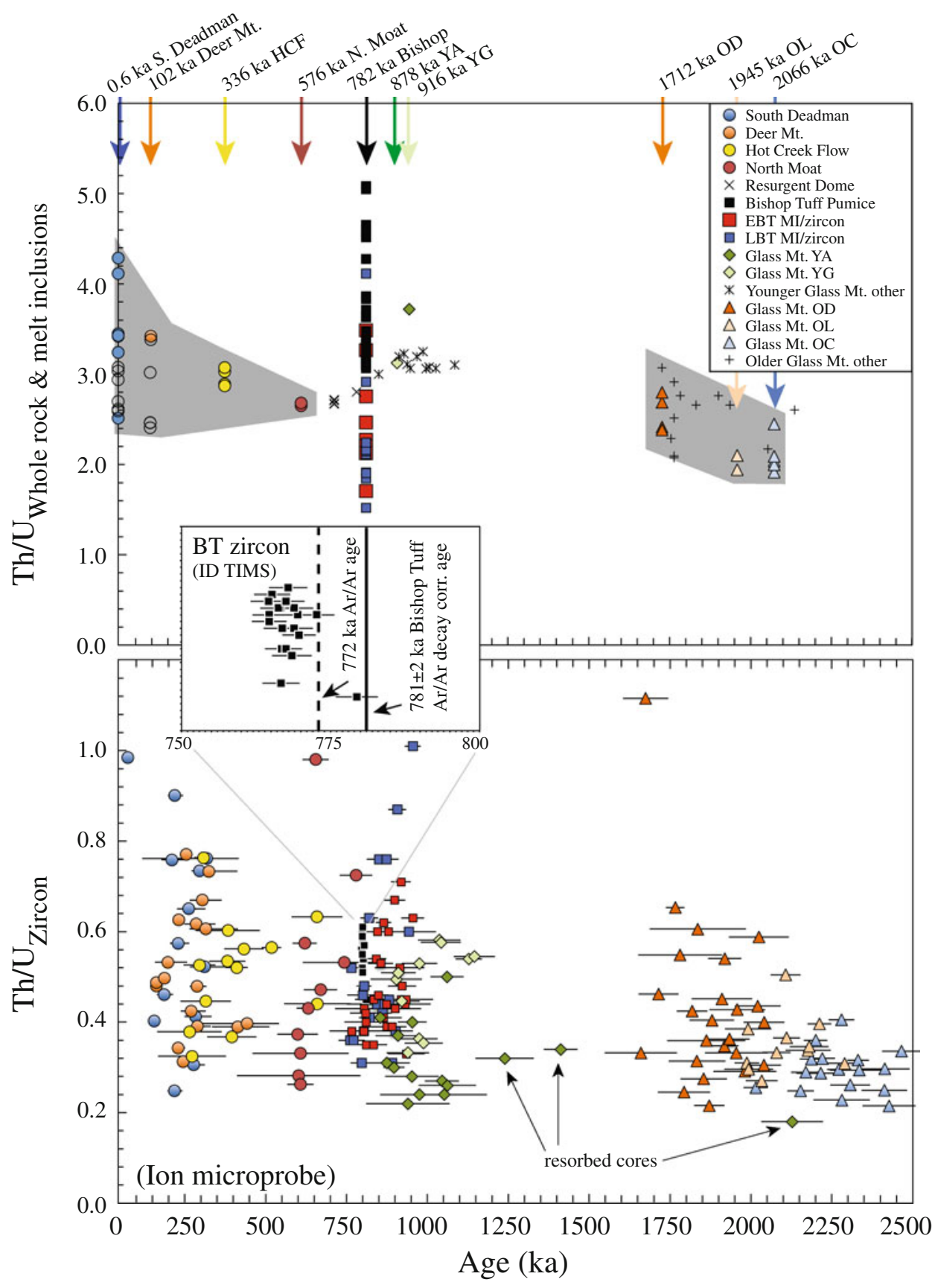

2013; Wallace et al. 1999). Studies of the differentiation, and physical and thermal conditions of magmatic reservoirs at Long Valley (Davies and Halliday 1998; Davies et al. 1994; Halliday et al. 1989; Heumann and Davies 1997; Mahood 1990; Metz and Mahood 1985, 1991; Simon et al. 2007), preeruptive residence times of these magmas (Christensen and DePaolo 1993; Christensen and Halliday 1996; Crowley et al. 2007; Davies and Halliday 1998; Gualda et al. 2012; Reid and Coath 2000; Reid et al. 1997; Simon and Reid 2005; Simon et al. 2007; van den Bogaard and Schirnick 1995), and how they may relate to the production of rhyolite extrusions remain debated (e.g., Reid 2008; Simon et al. 2008b).

Isotopic heterogeneity among and within Long Valley rhyolites

Secular variations in $\mathrm{Nd}, \mathrm{Pb}, \mathrm{Sr}$, and $\mathrm{O}$ isotopes have been documented for the Long Valley magmatic system (e.g., Bindeman and Valley 2002; Christensen and DePaolo 1993; Christensen and Halliday 1996; Davies and Halliday 1998; Davies et al. 1994; Halliday et al. 1989; Heumann 
and Davies 1997; Simon et al. 2007). These isotopic signatures potentially provide different perspectives to the history of Long Valley, including the evolution of it source compositions (i.e., $\mathrm{Nd}, \mathrm{Pb}$, and $\mathrm{Sr}$ isotopes), radiogenic ingrowth ( $\mathrm{Sr}$ isotopes), and magma-thermometry ( $\mathrm{O}$ isotopes). Each differs in detail, but broadly speaking all show a consistent trend where the magmatic system shifts from one that is dominated by a crustal source to one in which crustal magma reservoirs are spiked by influx of isotopically more primitive mantle-derived melts. The new $\mathrm{Nd}$ and Hf whole rock data are consistent with this general trend (Figs. 6, 7).

Existing $\mathrm{Nd}, \mathrm{Pb}, \mathrm{Sr}$, and $\mathrm{O}$ isotope crystal population studies of quartz and/or feldspars reflect evolution (e.g., increasing $\mathrm{Nd}$, decreasing $\mathrm{Pb}$, and $\mathrm{Sr}$ trends) toward mantlederived signatures, in particular between the eruption of precaldera and late caldera-forming magmas, but greater heterogeneity is found at the mineral scale (Bindeman and Valley 2002; Christensen and Halliday 1996; Davies and Halliday 1998; Halliday et al. 1984, 1989; Heumann and Davies 1997; Simon et al. 2007). The Hf isotopic variability observed $\left(\varepsilon_{\mathrm{Hf}}=\sim-2\right.$ to $\left.\sim 4\right)$ among the studied zircon populations is also greater, but generally consistent with the secular isotopic shifts seen at the whole rock scale (Fig. 7). Previously, some mineral isotope compositions observed in younger extrusions have been used to suggest a direct cogenetic relationship between younger rhyolites, in particular the Bishop Tuff magma, to older precaldera rhyolite magmas at Long Valley. For example, model $\mathrm{Rb}-\mathrm{Sr}$ ages calculated for the most radiogenic crystals are young enough (within $\leq 1,000 \mathrm{ka}$ of their respective eruption) that they cannot be dismissed outright. Likewise some of these crystals appear to share $\mathrm{Nd}$ and $\mathrm{Sr}$ isotopic affinities with some older rhyolites (cf. Davies and Halliday 1998; Halliday et al. 1989; Mahood 1990; Simon et al. 2007). However, as discussed below, zircon dating studies are often at variance with these old model ages (e.g., Simon and Reid 2005). The zircon crystallization ages place a robust limit on the age and thus the possibility of a substantially older origin of the feldspars because dissolution of any putative old zircon would only occur under thermochemical conditions in the magma that would also lead to resorption of any accompanying feldspar. In addition, feldspar $\mathrm{Sr}$ and $\mathrm{Pb}$ isotopes conspicuously fall along crust-mantle mixing curves (see Fig. 5 of Simon et al. 2007). This implies that a component of the $\mathrm{Sr}$ isotopic variability is due to open-system

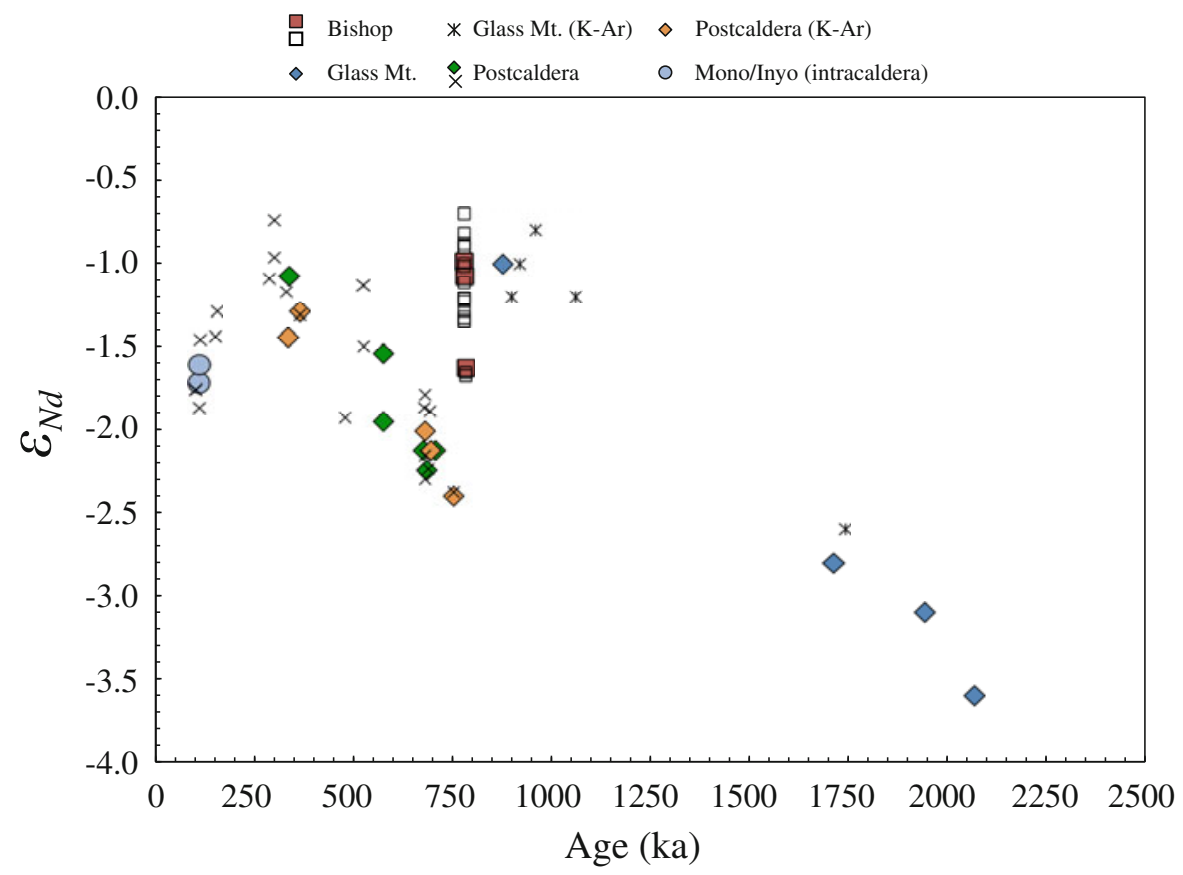

Fig. $6 \mathrm{Nd}$ isotope composition of whole rocks (filled symbols, this study) versus eruption age (ka) superimposed on existing data (other symbols) for Long Valley rhyolites. When possible, the Ar/Ar dating from Simon et al. (2007, Simon et al. 2008a, b, this study) was used for postcaldera rhyolites (green diamonds), precaldera rhyolites (blue diamonds), and Bishop Tuff (red squares). The exceptions include Ar/Ar dating of Davies and Halliday (1998) for late postcaldera (blue circles) and K-Ar dating of Bailey et al. (1976) for postcaldera rhyolites (orange diamonds). Bishop Tuff Nd data from Davies and Halliday (1998); Halliday et al. (1984) are shown by open squares.
Precaldera Nd data from Davies and Halliday (1998) and Davies et al. (1994) plotted versus K-Ar ages (Bailey et al. 1976) shown with asterisks. Postcaldera $\mathrm{Nd}$ data and $\mathrm{Ar} / \mathrm{Ar}$ data from Davies and Halliday (1998) plotted as "x's," which shows secular shifts in Nd over time periods of 100's ka, but melt compositions likely changed more rapidly (10's ka) perhaps continuously as indicated by $\varepsilon_{\mathrm{Nd}}$ (e.g., Christensen and Depaolo 1993; Halliday et al. 1984) and $\varepsilon_{\mathrm{Hf}}$ (this study, see Fig. 7) isotope heterogeneity found within their individual crystal populations 
Fig. $7 \mathrm{Hf}$ isotope composition of whole rocks and zircon crystals versus eruption age (ka) for studied Long Valley rhyolites. Sample symbols shown in legend. Secular shifts in $\varepsilon_{\mathrm{Hf}}$ over time periods of 100's ka are observed, but melt compositions likely changed more rapidly (10's ka) perhaps continuously as indicated by the $\varepsilon_{\mathrm{Hf}}$ heterogeneity found within their individual zircon populations. Dashed arrows indicate approximate age span and sense of melt differentiation recorded by $\mathrm{Th} / \mathrm{U}$

measurements from the dated zircon population of the studied rhyolites (Simon and Reid 2005; Simon et al. 2007; and this study)

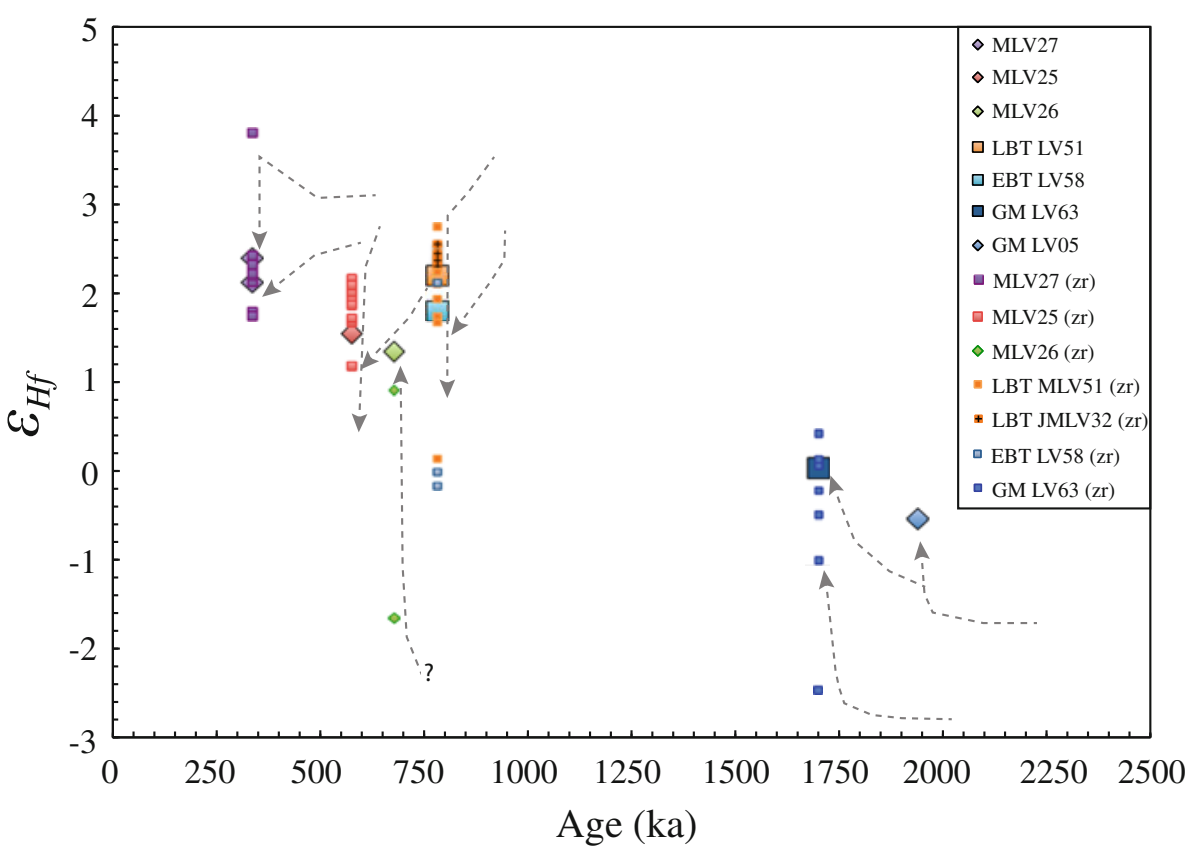

interaction with preexisting crust (probably hydrothermally altered predecessors, Hildreth and Wilson 2007; Schmitt and Simon 2004; Simon et al. 2007) and not entirely to radioactive ingrowth. This is because unlike the $\mathrm{Sr}$ isotope variations in high $\mathrm{Rb} / \mathrm{Sr}$ phases, $\mathrm{Pb}$ isotope differences cannot be explained by aging (cf. Wolff and Ramos 2003). Therefore, feldspars with radiogenic ${ }^{87} \mathrm{Sr}$-excesses may be antecrysts (e.g., Charlier et al. 2005)—crystals related to the system but not necessarily to the magma in which they are erupted.

Regardless of the $\mathrm{Sr}$ model ages being unreliable to constrain magmatic differentiation and residence, the fact that some crystals in the younger rhyolites share $\mathrm{Nd}$ isotopic affinities with the older rhyolites is still used as evidence for crystal carryover and thus appears to support claims for a long-lived interconnected magma body. Do these antecrysts originate from older rhyolitic magma reservoirs and thus support carryover of "crystal-cargo" from the older rhyolites, i.e., from the magma reservoir that produced Older Glass Mountain rhyolites to the Bishop Tuff magma? Akin to the isotopically heterogeneous feldspars, some zircon in the postcaldera rhyolites, i.e., the $\sim 575 \mathrm{ka}$ North Moat rhyolite (JIS06MLV026) and the Bishop Tuff have Hf isotope compositions that are similar to those observed in the precaldera Older Glass Mountain rhyolites. Notably, none of the zircon dated from postcaldera rhyolites or the Bishop Tuff (oldest grains are $\leq 900 \mathrm{ka}$ ) have ages that are as old as those from any of the Older Glass Mountain rhyolites $(\geq 1,700 \mathrm{ka}$ ) (Simon and Reid 2005; Simon et al. 2007, and this study). Moreover, only a single $\mathrm{U}-\mathrm{Pb}$ zircon analysis from the postcaldera $\sim 575$ ka North Moat rhyolite is old enough to have grown at the same time at which the Bishop Tuff magma(s) resided in the crust. These new data provide a link between the wealth of isotopic tracer and the geochronology studies and help to interpret the crystal record contained within individual eruptions. Based on their ages and $\mathrm{Hf}$ isotopic compositions, they imply little to no crystal carryover from older to younger magmas for both pre- and postcaldera magmas and suggest the existence of transient melt bodies throughout the life time of the system rather than the existence of a long-lived integrated magma chamber (Simon and Reid 2005). Hf isotopic variations among zircon contained within a single rhyolite can only be reconciled by the operation of open-system processes that are capable of shifting the ${ }^{176} \mathrm{Hf} /{ }^{177} \mathrm{Hf}$ ratio of the melt $\left(\varepsilon_{\mathrm{Hf}}=2-3\right)$ from which the zircons crystallized. Furthermore, the isotopic signatures in zircon provide a direct answer to the question of whether crystallization occurs before, during, or after mixing of crustal and mantlederived components (Fig. 7). In the case of precaldera Glass Mountain dome OD (MR00LV63), most zircons crystallized from a melt that had a lower ${ }^{176} \mathrm{Hf} /{ }^{177} \mathrm{Hf}$ (more evolved) composition than the bulk rock, suggesting that the mantle component increased in the melt through time. In contrast, most zircons that crystallized in the Bishop Tuff and postcaldera rhyolites have ${ }^{176} \mathrm{Hf} /{ }^{177} \mathrm{Hf}$ compositions similar to and in some instances even higher (more mantle-like) than the bulk rock. The exceptions are the few anomalously low ${ }^{176} \mathrm{Hf} /{ }^{177} \mathrm{Hf}$ zircon crystals found in the $676 \mathrm{ka}$ Resurgent Dome and Bishop Tuff rhyolites described above. Rhyolites dominated by zircon with ${ }^{176} \mathrm{Hf} /{ }^{177} \mathrm{Hf}$ compositions higher than their hosts are interpreted to reflect greater primitive magma influx during magma differentiation. The isotopically more mantle-like 
zircon likely crystallized from an initially more primitive melt before it was subsequently modified by contamination via crustal assimilation. In such a scenario, the bulk rock and the rare zircons with ${ }^{176} \mathrm{Hf} /{ }^{177} \mathrm{Hf}$ compositions lower than their host may reflect an evolving melt composition related to late stage partial assimilation of young silicic intrusions (Schmitt and Simon 2004), but not crystal carryover from a long-lived crystal mush.

A case can be made for relatively rapid melt differentiation given the relatively narrow zircon age populations found in the Bishop Tuff and $~ 576$ ka North Moat rhyolites (see below). Because the scale of Hf isotopic variability among Long Valley rhyolites is too small to be resolved by current in situ laser ablation techniques (cf. Kemp et al. 2007), the sense of $\mathrm{Hf}$ isotope evolution during zircon growth and thus magma evolution cannot be determined directly. This can, however, be examined by looking at the evolution of melt (cf. Th/U ratios) recorded by the zircon crystal populations themselves which provide a proxy for the degree of differentiation (see Fig. 7 and discussed in detail below).

Magma residence time and the interpretation of Pleistocene rhyolite ages

Comparing U-Th- $\mathrm{Pb}$ and ${ }^{40} \mathrm{Ar} /{ }^{39} \mathrm{Ar}$ data sets such as those presented herein and reported previously (Crowley et al. 2007; Heumann et al. 2002; Reid and Coath 2000; Reid et al. 1997; Rivera et al. 2011; Sarna-Wojcicki et al. 2000; Simon and Reid 2005; Simon et al. 2007, 2008b) provides a more direct and arguably a more accurate means for determining the subvolcanic magma residence time span as compared to estimates based on the repose interval between eruptions (e.g., Spera and Crisp 1981) or those based on ${ }^{40} \mathrm{Ar} /{ }^{39} \mathrm{Ar}$ and $\mathrm{Rb} / \mathrm{Sr}$ model ages (e.g., Christensen and DePaolo 1993; van den Bogaard and Schirnick 1995). At Long Valley, when compared to magma residence times estimated from ${ }^{40} \mathrm{Ar} /{ }^{39} \mathrm{Ar}$ contained in melt inclusions or $\mathrm{Rb} / \mathrm{Sr}$ crystal model ages of 100 's to $1,000 \mathrm{ka}$, the zircon-based estimates are markedly shorter (i.e., $\leq 100$ 's of ka and not $\geq 500 \mathrm{ka}$ ). The relatively short ( $\leq 50-70 \mathrm{ka})$ magma residence time based on $\mathrm{U}-\mathrm{Th}-\mathrm{Pb}$ age determinations for zircon contained in the Bishop Tuff (e.g., Crowley et al. 2007; Reid and Coath 2000; Simon and Reid 2005) exemplifies this difference.

At face value, the preeruption time spans at Long Valley, which range from no resolvable time (e.g., Fig. 3 in this study) to 100's ka (e.g., Reid et al. 1997; Simon and Reid 2005, this study), record the duration over which magmas were produced. In detail, the geologic significance of the preeruptive interval is less clear. It could reflect the storage interval of crystals growing in melt, i.e., a "magma residence" time. More specifically, these age spans may reflect minimum estimates of the time that magma was stored in the crust because the magmas were zirconundersaturated (Watson and Harrison 1983) and/or resided in the deeper crust (cf. Dufek and Bergantz 2005) for parts of their history. Alternatively, the preeruption ages could reflect times where there was subvolcanic magma, but it is possible these zircons are unassociated with the erupted magma itself and thus not strictly related to its preeruption magma storage time. In terms of the unrelated crystals, the age spread would be due to remobilization of zircon from a collection of magmas, crystalline mushes, and/or subvolcanic plutons by the introduction of new melt. Although the process of partially remelting young intrusions may have contributed somewhat to the span of ages erupted for some zircon populations at Long Valley, it is unlikely that the observed protracted zircon crystallization interval simply reflects the remobilization from just a couple of short-lived ( $<10$ 's ka) granitic intrusions that extruded the Older and Younger Glass Mountain rhyolites, respectively, as envisioned by Sparks et al. (1990).

\section{Age constraints for the climactic Bishop Tuff}

Comparing the ${ }^{40} \mathrm{Ar} /{ }^{39} \mathrm{Ar}$ and $\mathrm{U}-\mathrm{Th}-\mathrm{Pb}$ ages of a rhyolite to determine its magma residence time has historically been complicated by uncertain intercalibration between these two chronometers (e.g., Channell et al. 2010; Kuiper et al. 2008; Min et al. 2000; Rivera et al. 2011). Although this uncertainty has little direct bearing on the main conclusions of this study, the age of the Bishop Tuff (cf. Channell et al. 2010; Crowley et al. 2007; Renne et al. 2010; Rivera et al. 2011; Simon et al. 2008a) has become central to this issue and to magma generation timescales in general. Crowley et al. (2007) determined a precise weighted mean zircon $\mathrm{U}-\mathrm{Pb}$ age of $767 \pm 0.5(n=17 / 19)$ by chemical abrasion isotope dilution thermal ionization mass spectrometry (ID-TIMS). At face value, this age appears to be compatible with the slightly younger mean $759 \pm 2 \mathrm{ka}(n=70){ }^{40} \mathrm{Ar} /{ }^{39} \mathrm{Ar}$ eruption age reported by Sarna-Wojcicki et al. (2000) and indistinguishable if this age is recalculated to $770 \pm 2 \mathrm{ka}$ using the calibration of Renne et al. (1998) as was done by Crowley et al. (2007). However, this apparent consistency disappears if the ${ }^{40} \mathrm{Ar} /{ }^{39} \mathrm{Ar}$ age of Sarna-Wojcicki et al. (2000) is recalculated ( $778 \mathrm{ka}$ ) using the optimized calibration of Renne et al. (2011). Other recently proposed ${ }^{40} \mathrm{Ar} /{ }^{39} \mathrm{Ar}$ calibrations (Channell et al. 2010; Rivera et al. 2011) yield younger ages for the Bishop Tuff and thus appear to eliminate the apparent conundrum of zircon forming after the eruption. However, these new calibrations are mutually incompatible, and therefore, either one or both must be wrong (Renne 2013). The new ${ }^{40} \mathrm{Ar} /{ }^{39} \mathrm{Ar}$ age in this study of $780 \pm 2 \mathrm{ka}$ (using the calibration of Renne et al. 2011) 
for sanidine extracted from two pumice clasts $(n=50)$ is consistent with the measurements of Sarna-Wojcicki et al. (2000) when normalized to the same calibration. Rivera et al. (2011) also report a new ${ }^{40} \mathrm{Ar} /{ }^{39} \mathrm{Ar}$ age for the Bishop Tuff $(767.4 \pm 1.1 \mathrm{ka}, n=14 / 15)$ based on their own astronomically calibrated age of $28.172 \mathrm{Ma}$ for the Fish Canyon Tuff sanidine (FCs) standard. The difference between our ages for the Bishop Tuff and those of Rivera et al. (2011) is not solely a result of the different calibrations used. Renne (2013) showed that the Rivera et al. (2011) data and those of Sarna-Wojcicki et al. (2000) are analytically distinct, with $R$ values $\left({ }^{40} \mathrm{Ar} \times 1{ }^{39} \mathrm{Ar}\right.$ of the Bishop Tuff sanidine relative to that of the FCs standard) of $0.02706 \pm 0.0005$ and $0.02728 \pm 0.00007$, respectively. Our new data presented here yield an $R$ value of $0.02736 \pm 0.00007$, agreeing with that of Sarna-Wojcicki et al. (2000) but not Rivera et al. (2011). Thus, we have a large number of replicates $(n=120)$ from multiple samples of Bishop Tuff analyzed in two laboratories that yield internally consistent results, and these are analytically distinct from results obtained from a single sample in one laboratory $(n=15)$. Our data pooled with those of SarnaWojcicki et al. (2000) yield a weighted mean $R$ value of $0.02732 \pm 0.00006$. Using either of the astronomical ages ascribed to FCs by Rivera et al. (2011) or Kuiper et al. (2008) and consistent with the ID-TIMS data of Wotzlaw et al. (2013), this $R$ value translates to ages of $775 \pm 2$ or $776 \pm 2 \mathrm{ka}$, respectively. Thus, even using the youngest modern calibration of the ${ }^{40} \mathrm{Ar} /{ }^{39} \mathrm{Ar}$ system applied to the most coherent ${ }^{40} \mathrm{Ar} /{ }^{39} \mathrm{Ar}$ data for the Bishop Tuff yields an age distinctly older than the inferred $\mathrm{U}-\mathrm{Pb}$ zircon age of Crowley et al. (2007). We believe that the zircon U-Pb IDTIMS age likely reflects an oversimplified U-series disequilibrium correction, to which Pleistocene $\mathrm{U}-\mathrm{Pb}$ zircon ages are highly sensitive. The ${ }^{206} \mathrm{~Pb}^{*} /{ }^{238} \mathrm{U}$ system requires a disequilibrium correction of typically 6-15\% or roughly 80-90 ka for the age of the Bishop Tuff (Schärer 1984; Simon et al. 2008a, b). One of the variables involved in the correction is the $\mathrm{Th} / \mathrm{U}$ value of the host melt. The $\mathrm{Th} / \mathrm{U}$ estimate for a compositionally heterogeneous (i.e., evolving) magma body is difficult to define and can have a relatively large effect on the absolute age and its uncertainty. The crystallization of zircon and other accessory phases (e.g., allanite) can have a large effect on the residual Th/U (melt) value (cf. Fig. 7 of Heumann et al. 2002). It follows that the mean $\mathrm{Th} / \mathrm{U}$ (melt) value of $2.81 \pm 0.16$ (1 s) used by Crowley et al. (2007) from a subset of the published data for quartz-hosted melt inclusions (Anderson et al. 2000) may not represent the melt composition from which the dated zircon grew. This point is further emphasized by considering the much wider range of pumice whole rocks compositions reported (i.e., $\mathrm{Th} / \mathrm{U}$ (melt) $=3.1-5.1$ of Hildreth 1977, Fig. 5). It is therefore appropriate to question the validity of whether relatively late forming quartz would trap melt that represents the composition from which the dated zircon grew. Furthermore, the Th/U (melt) value employed by Crowley et al. (2007) likely does not adequately represent the host melt because melt inclusions in quartz phenocrysts vary more greatly than the range that they considered (i.e., Th/U $\sim$ 1.5-4.1, Schmitt and Simon 2004) and generally record more evolved magma than the whole rock pumice. In fact, a greater range and generally lower $\mathrm{Th} / \mathrm{U}$ are observed in melt inclusions, whether or not the quartz crystals were derived from an early evolved or a late less evolved melt, i.e., pumice whole rock clast (Schmitt and Simon 2004). If the average pumice $\mathrm{Th} / \mathrm{U}$ (melt) composition from Hildreth and Wilson (2007) of $3.5(n=424)$ is used, the weighted mean age for the zircon ID-TIMS data increases to $\sim 771 \mathrm{ka}$ and if a Th/U (melt) composition of 4.5, similar to that found in many of the late erupting pumice, is assumed the ID-TIMS age becomes $\sim 775 \mathrm{ka}$. Both are within error of the preferred ${ }^{40} \mathrm{Ar} /{ }^{39} \mathrm{Ar}$ eruption ages (Sarna-Wojcicki et al. 2000; this study). Further analysis of the discrepancies between various ${ }^{40} \mathrm{Ar} /{ }^{39} \mathrm{Ar}$ sanidine and ID-TIMS U-Pb zircon ages for the Bishop Tuff would be fruitful in general, but is beyond the scope of this paper.

In addition to the discrepancy between the ${ }^{40} \mathrm{Ar} /{ }^{39} \mathrm{Ar}$ and $\mathrm{U}-\mathrm{Pb}$ ID-TIMS ages as reported, there are obvious differences between the published ID-TIMS and secondary ion microprobe (SIMS) zircon ages, namely the wealth of SIMS data that imply that zircons begin to crystallize around 830-850 ka ago in the Bishop Tuff magma (Reid and Coath 2000; Simon and Reid 2005). Next, we summarize concerns and differences in these data sets and offer plausible explanations. Zircon crystals saturate early (i.e., near the liquidus) in metaluminous rhyolite magmas and therefore likely record the changing melt composition over a protracted temperature interval. For this reason, individual zircon crystals are often zoned (both compositionally and with respect to age). In fact, zoning in Bishop Tuff zircon is well established by various analytical approaches (e.g., Crowley et al. 2007; Reid and Coath 2000; Reid et al. 2011; Simon and Reid 2005).

Simon et al. (2008b) considered the effect of unrecognized heterogeneity (i.e., older cores) when dating individual zircon grains. These considerations are the same whether the heterogeneity (i.e., zoning) is magmatic or due to inheritance. The geometric and compositional effects on the accuracy of individual zircon ages, due to age and compositional zoning, can be found in Simon et al. (2008b). This forward modeling approach quantitatively shows how the mean ages (e.g., obtained by ID-TIMS) will be weighted toward younger ages because of the greater volume of late, often U-rich, growth measured. In contrast, most SIMS ages, and certainly those reported for Long 
Valley rhyolites (i.e., R99LV58 that yields a mean age $=841 \pm 8 \mathrm{ka}, \mathrm{MSWD}=0.9, n=29 ; 061498-24-6$ that yields a mean age $=822 \pm 10 \mathrm{ka}, \mathrm{MSWD}=0.9$, $n=22$; and R99LV51 that yields a mean age $=810 \pm 7 \mathrm{ka}, \mathrm{MSWD}=3.3, n=20$, from Reid and Coath 2000 and Simon and Reid 2005), are obtained from spots with lateral dimensions of $\sim 20 \mu \mathrm{m}$ in diameter which were placed within the core of zircons. Even when crystals rims were targeted, the beam overlap with interior domains will bias the SIMS age toward the crystal interiors, whereas a significant volume of zircon in the crystal rims will be underrepresented unless alternative SIMS techniques are applied (e.g., depth profiling; Reid and Coath 2000). Thus, zoning that has been measured in Bishop Tuff zircon (Simon and Reid 2005) helps to explain the apparent difference between the older mean age and significant age spread determined by SIMS and the younger ages based on the more limited number, but more precise ID-TIMS zircon analyses. Considering both the sampling differences between SIMS and ID-TIMS (and the likely bias toward the outer high [U] and younger ages in the IDTIMS work) and the more realistic uncertainty that should be assigned to the ID-TIMS ages, the apparent disparity between ${ }^{40} \mathrm{Ar} /{ }^{39} \mathrm{Ar}$ eruption, the precise ID-TIMS, and older zircon SIMS (core) ages can all be reconciled.

\section{Ages for other Long Valley rhyolites}

At Long Valley, zircon age populations have been reported for a number of rhyolite extrusions in addition to the Bishop Tuff (Heumann et al. 2002; Reid et al. 1997; Simon and Reid 2005; Simon et al. 2007, 2008b). Zircon ages have been measured in five of the precaldera Glass Mountain domes and show no evidence for inheritance of zircons older than the Long Valley magmatic system (Simon and Reid 2005). In all five Glass Mountain rhyolites, the zircon crystallization ages range from tens to hundreds of ka before eruption and generally support the inference of 10's-100's ka preeruption magma residence times. In more detail, the mean preeruption ages of the 2,059 ka Glass Mountain (GM) OC dome is 2,301 $\pm 15 \mathrm{ka}$ (MSWD $=1.85, n=13$ ), the $1,939 \mathrm{ka}$ GM OL dome is $2,153 \pm 15 \mathrm{ka}(\mathrm{MSWD}=2.03, n=11)$, the $1,699 \mathrm{ka}$ GM OD dome is $1,904 \pm 15 \mathrm{ka}(\mathrm{MSWD}=1.31, n=20)$, the $916 \mathrm{ka} \mathrm{GM} \mathrm{YG} \mathrm{dome} \mathrm{is} 984 \pm 22 \mathrm{ka}(\mathrm{MSWD}=1.46$, $n=10$ ), and the $875 \mathrm{ka} \mathrm{GM} \mathrm{YA} \mathrm{dome} \mathrm{is} 999 \pm 19 \mathrm{ka}$ (MSWD $=2.16, n=9$ ). From oldest to youngest, these zircon age populations imply progressively decreasing residence time $(\tau)$ of $244 \pm 25,214 \pm 28,205 \pm 26$, $68 \pm 43$, and $123 \pm 24 \mathrm{ka}$, respectively (cf. the SIMS zircon age population measured in the Bishop Tuff imply $\tau$ $\sim 50 \pm 10 \mathrm{ka})$.
The new U-Th-Pb SIMS zircon ages reported herein for postcaldera rhyolites complement the pioneering work of Heumann et al. (2002) and Reid et al. (1997) for some of the most recent eruptions at Long Valley caldera, including the $0.6 \mathrm{ka}$ South Deadman Dome, the 102 ka Deer Mountain, the 110 ka Mammoth Knolls, and the $\sim 153 \mathrm{ka}$ Low Silica Rhyolite flow. At face value, the new zircon ages measured in the $336 \mathrm{ka} H$ Creek flow rhyolite (JS06MLV27) and the 576 ka North Moat rhyolite (JS06MLV25) exhibit mean U-Th-Pb zircon ages that are within error of their respective eruptions. The precision of $\mathrm{U}-\mathrm{Th}-\mathrm{Pb}$ zircon ages over the $\sim 250-400 \mathrm{ka}$ age range is compounded by their low amount of ${ }^{206} \mathrm{~Pb}$ radiogenic ingrowth and the comparatively large U-series disequilibrium age correction. Nevertheless, the relatively high goodness-of-fit parameter $(\mathrm{MSWD}=4.45)$ and calculated mean preeruption age of $490 \pm 25 \mathrm{ka}(n=12)$ indicate that the Hot Creek flow rhyolite contains zircon that may have predated eruption by as much as $154 \pm 27 \mathrm{ka}$. Unlike the Hot Creek flow and other young Long Valley rhyolitic extrusions that exhibit significant preeruption crystallization age populations (from $\sim 30 \mathrm{ka}$ in the Mammoth Knolls to $\sim 200 \mathrm{ka}$ for Deer Mountain rhyolites, Heumann et al. 2002; Reid et al. 1997), there is minimal evidence for preeruption magma residence or a resolvable differences among zircon ages in the $576 \pm 7 \mathrm{ka}$ North Moat rhyolite (mean zircon age is $613 \pm 16$, MSWD $=1.13, n=10$ ).

The $102 \mathrm{ka}$ Deer Mountain Dome is the only rhyolite at Long Valley beside the Bishop Tuff where both SIMS and ID-TIMS zircon age determinations have been reported (Heumann et al. 2002; Reid et al. 1997), albeit by U-Th not $\mathrm{U}-\mathrm{Th}-\mathrm{Pb}$ dating. Both approaches suggest that the Deer Mountain magma underwent protracted crystallization. Analogous to differences observed among Bishop Tuff zircon measurements, the weighted mean preeruption age (194 $\pm 7 \mathrm{ka}, n=10)$ derived from SIMS analysis is less precise than the ID-TIMS zircon-glass model age $(254 \pm 3.5 \mathrm{ka})$. Furthermore, the $\mathrm{Th} / \mathrm{U}$ compositions determined for zircon by SIMS range from slightly lower values to values that are a factor of $\sim 2$ greater than determined by ID-TIMS. We suspect that this is a similar case where much of the temporal and compositional variability contained in the zircon record has been obscured by mixing over multiple crystal domains, as we have discussed in the comparison between Bishop Tuff IDTIMS and SIMS U-Pb zircon ages. Heumann et al. (2002) interpret the preeruptive zircon U-Th model age as indicative of protracted magma residence time. This interpretation is consistent with the SIMS U-Th measurements of individual zircons in this dome (Reid et al. 1997). 
Except for one model U-Th zircon age at $\sim 30 \mathrm{ka}$, and a couple at $\sim 100 \mathrm{ka}$, most zircons dated from the $0.6 \mathrm{ka}$ South Deadman Dome rhyolite cluster around 175-250 ka (see Figure 3 of Reid et al. 1997), significantly older than the age of eruption. Reid et al. (1997) considered the possibility that apparent age gaps between $\sim 100$ and $\sim 30 \mathrm{ka}$ and then to $0.6 \mathrm{ka}$ reflect remobilization of a near or completely solidified leucogranite. They ultimately argued that the chemical affinities between the South Deadman Dome and Deer Mountain Dome rhyolites and the euhedral zircon are more consistent with residence in a common long-lived magma reservoir. As suggested previously for these protracted zircon age populations (Reid et al. 1997) and discussed more generally below in order to maintain magmatic temperatures for periods of 10's ka, there must be an additional heat source (e.g., Annen 2009). The wealth of isotopic heterogeneity found among the Long Valley rhyolites and among the zircon crystals that they contain (this work) implies open-system evolution and supports the hypothesis that this thermal influx could be provided by intrusion of less evolved magmas (e.g., Christensen and DePaolo 1993; Heumann and Davies 1997; Simon et al. 2007).

In summary, the comparison between zircon ages and ${ }^{40} \mathrm{Ar} /{ }^{39} \mathrm{Ar}$ eruptions ages for representative rhyolite extrusions from the precaldera, caldera, and postcaldera periods often exhibit significant preeruption crystallization (Fig. 11). The magmas that erupted prior to caldera collapse appear to show a secular decrease in their apparent magma residence times over time (Simon et al. 2007). This trend may continue through eruption of the caldera-related Bishop Tuff and to some of the earliest rhyolites in the postcaldera period (i.e., North Moat rhyolite appears to have negligible preeruption zircon growth, this study). After this point in time, there seems to be a reversal in the preeruption crystallization periods, in which they expand again as the system evolves, back to time spans that are comparable to the precaldera Older Glass Mountain rhyolites (see inset in Fig. 11). Possible explanations for this trend, such as it is, are discussed below, but it is not one that can be easily predicated by volume-frequency arguments (Crisp 1984). In fact, the volume and preeruption time period appear to reflect an inverse correlation (cf. Simon et al. 2008b). Long Valley rhyolites exhibit variable magma residence times, and as discussed next, likely reflect external parameters (e.g., varying mantle-derived mafic magma input).

\section{Temporal constraints for geochemical trends found among Long Valley rhyolites}

The whole rock compositions of Long Valley rhyolites define a coherent fractional crystallization differentiation trend (see the inset of Fig. 8 showing $\mathrm{CaO}$ vs. $\mathrm{TiO}_{2}$ ). Yet, the temporal eruption sequence of the Long Valley rhyolites (Fig. 8), and the isotopic heterogeneities, invalidates such a simple scenario. Likewise, the major element trends observed in the younger rhyolites $(<400 \mathrm{ka})$ clearly show that progressive differentiation of a single magma body is unrealistic. Another possibility based on the varying major element data is that the extrusions erupted between $\sim 2,050$ to $\sim 600 \mathrm{ka}$ reflect downward extraction from a zoned long-lived magma body (i.e., the long-lived "mush model" magma chamber), inverting the compositional zoning with sequential eruption. However, as discussed above and supported by results in Crowley et al. (2007), Simon and Reid (2005), Simon et al. (2007), and this study, the discrete crystal populations and virtual lack of zircon carryover does not support this scenario. Rather, the zircon studies indicate that the extrusions are the result of transient melts that represent discrete episodes of silicic magma genesis.

Variations of some trace elements follow the coherent differentiation trends of the major elements. For example, trace element contents reflecting fractionation involving phenocrysts minerals (primarily quartz, feldspar, biotite, \pm pyroxene) such as $\mathrm{Rb}, \mathrm{Ba}$, and $\mathrm{Sr}$ in the postcaldera rhyolites (Heumann and Davies 1997; this study) are consistent with major element compositions being chemically less evolved relative to the precaldera rhyolites (Davies et al. 1994; Metz and Mahood 1991). However, the abundances of some trace elements like the REEs and the high field strength elements (e.g., $\mathrm{Zr}, \mathrm{Th}, \mathrm{U}$, and $\mathrm{Nb}$ ) that are controlled by accessory minerals (zircon, allanite, and apatite) require at least two differentiation paths (Davies et al. 1994; Heumann and Davies 1997; Metz and Mahood 1991; this study Fig. 9). Previous studies have argued that REE variations (e.g., La/Sm), especially those observed over the time period between the $\sim 700$ and the $\sim 336 \mathrm{ka}$ Hot Creek flow eruptions, would require fractionation of accessory minerals or mafic minerals like amphibole in percentages that exceed those present in the rocks. These studies conclude that either two distinct magma systems existed or portions of a large stratified body evolved independently at that time (Heumann and Davies 1997). In allanite-saturated rhyolites from Toba (Sumatra) and Coso (California), compositional shifts toward higher $\mathrm{La} / \mathrm{Nd}$ have been related to input of more mafic magma (e.g., Vazquez and Reid 2004; Simon et al. 2009). Addition of evolved magma and/or intrusions where allanite saturation has not occurred could also drive up $\mathrm{La} / \mathrm{Nd}$ values, i.e., that possibly exists among the Mesozoic granitoids (Fig. 9). The latter would be consistent with the observed coeval drop in $\mathrm{Nd}$ and $\mathrm{Hf}$ isotope compositions that imply addition of more crustal material (Figs. 6, 7). 


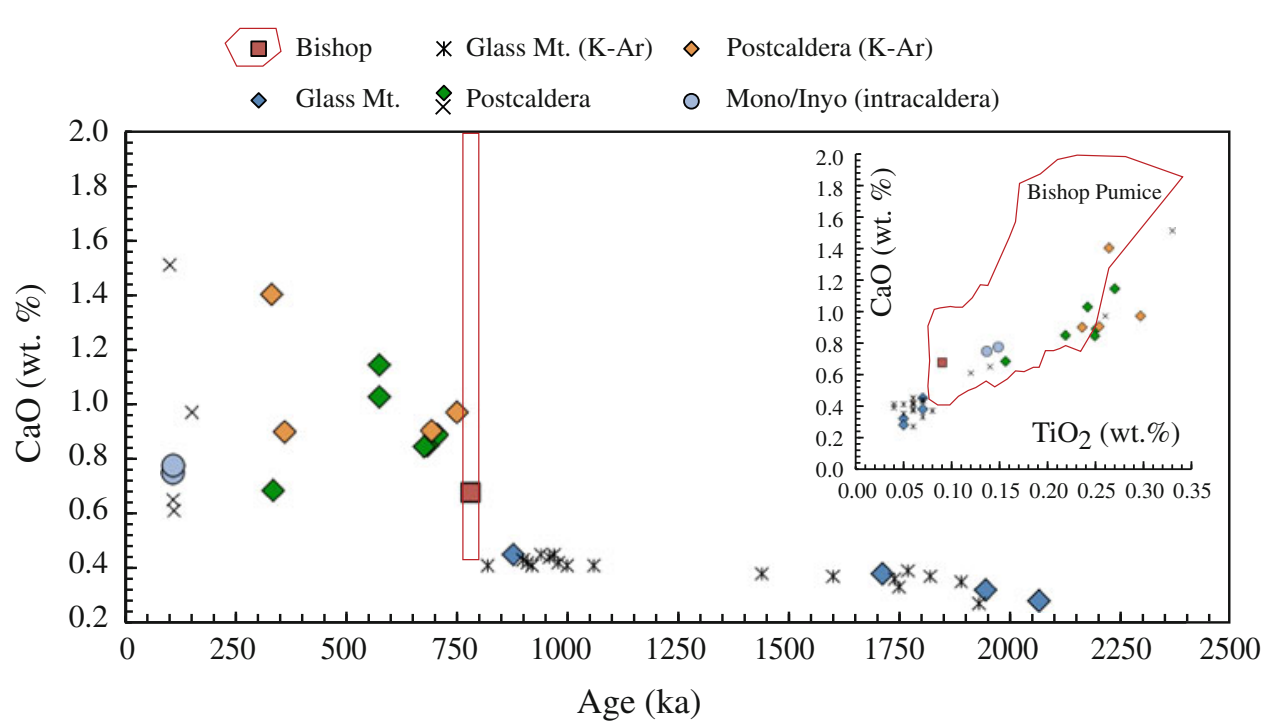

Fig. $8 \mathrm{CaO}$ whole rock compositions versus eruption age (ka) for Long Valley rhyolites. Sample symbols shown in legend. Major element trends from $\sim 2,050$ to $\sim 600 \mathrm{ka}$ have been interpreted to reflect downward extraction from a zoned magma body, inverting the compositional zoning of the magma chamber with sequential eruption. Younger rhyolites $(<400 \mathrm{ka})$ show that simple differentiation of a single large magma body is unlikely. Without the temporal

A detailed record of the melt evolution can potentially be found in the accessory minerals themselves. Here, we evaluate the $\mathrm{Th} / \mathrm{U}$ ratios in zircon (Fig. 5, bottom plot) which is potentially controlled by thermally and compositionally controlled saturation of accessory mineral, although we cannot rule out the effects of variable oxygen fugacity in the melt (e.g., Burnham and Berry 2012). The range of $\mathrm{Th} / \mathrm{U}$ compositions observed in zircon contained in the postcaldera rhyolites reported herein is similar to the range observed in zircon reported for other postcaldera rhyolites (Reid et al. 1997) and the Bishop Tuff (Reid and Coath 2000; Simon and Reid 2005), but exceeds that of all but one of the previously studied precaldera rhyolites (i.e., dome OD) (Simon and Reid 2005). This increased compositional range coupled with relatively brief zircon age spans may indicate that the subvolcanic magma systems that produced the Bishop Tuff and early postcaldera rhyolites were derived from magmas that evolved rather quickly. The similar range of $\mathrm{Th} / \mathrm{U}$ values, but longer magma residence time recorded by zircon contained in the youngest postcaldera rhyolites (i.e., Deer Mountain and South Deadman Dome), suggests that these magmas may have also evolved quickly, but were stored longer prior to their eruption. In contrast, the protracted age populations, their reduced $\mathrm{Th} / \mathrm{U}$ variability, and the lower $\mathrm{Th} / \mathrm{U}$ values characteristic of zircon contained in the precaldera Glass Mountain rhyolites indicate that once they were generated, the precaldera magmas underwent only moderate constraints $\mathrm{CaO}$ versus $\mathrm{TiO}_{2}$ whole rock data (inset) also appear to show a coherent differentiation trend. For reference, the range outlined in red represents a majority of Bishop Tuff pumice compositions from Hildreth and Wilson (2007), which is greater than originally reported, although these pumice are never as evolved as the most evolved precaldera rhyolite compositions

amounts of differentiation. The 1,699 ka dome OD Older Glass Mountain rhyolite is the exception. It exhibits a degree of variability in $\mathrm{Th} / \mathrm{U}$ values similar to many of the postcaldera rhyolites and the Bishop Tuff.

The overall evolution of the Long Valley magma system as reflected in the variation of zircon $\mathrm{Th} / \mathrm{U}$ values can be subdivided into three stages: (1) precaldera Older Glass Mountain rhyolites ending with the 1,699 ka precaldera dome OD, (2) precaldera Younger Glass Mountain rhyolites ending with the $\sim 700 \mathrm{ka}$ postcaldera rhyolites (including the Bishop Tuff), and (3) postcaldera $336 \mathrm{ka}$ Hot Creek flow expanding up until at least extrusion of the $102 \mathrm{ka}$ Deer Mountain Dome and possibly to the $0.6 \mathrm{ka}$ South Deadman Dome. These stages initiate with zircon crystallizing with comparatively low and homogeneous $\mathrm{Th} /$ $\mathrm{U}$ values (Fig. 5). The onset of these stages also correlates with prominent discontinuities in $\mathrm{Nd}$ and $\mathrm{Hf}$ isotopes with increases in $\varepsilon_{\mathrm{Nd}}$ and $\varepsilon_{\mathrm{Hf}}$ indicating the production of less evolved rhyolites either due to greater input of mafic, presumably mantle-derived, magma into the crust diluting the crustal component or from greater input of less evolved melt from the lower crust. Notably, while the oldest zircon crystals contained in the $\sim 336$ ka Hot Creek flow overlap in age with most of the zircon crystals contained in the $\sim 576 \mathrm{ka}$ postcaldera rhyolite, the range at that time in each $\mathrm{Th} / \mathrm{U}$ is at their least and most (Figs. 4, 5), respectively, for the two extrusions implying that these magma bodies coevolved for a time, but were unlikely interconnected. 
Fig. $9 \mathrm{La} / \mathrm{Nd}$ ratio versus eruption age (ka) for Long Valley rhyolites. Inset shows $\mathrm{La} / \mathrm{Nd}$ ratio versus $\mathrm{Zr} / \mathrm{Nb}$ ratio. Sample symbols shown in legend. REE and high field strength elements show at least two differentiation trends (black arrows). Not shown are the high values of Deer Mountain $(\sim 6.3$; Heumann and Davies 1997) and an early postcaldera rhyolite (4.3; Metz and Mahood 1991). Bishop Tuff data include those reported by Hildreth (1977); Hildreth and Wilson (2007), open squares; and this study, red square

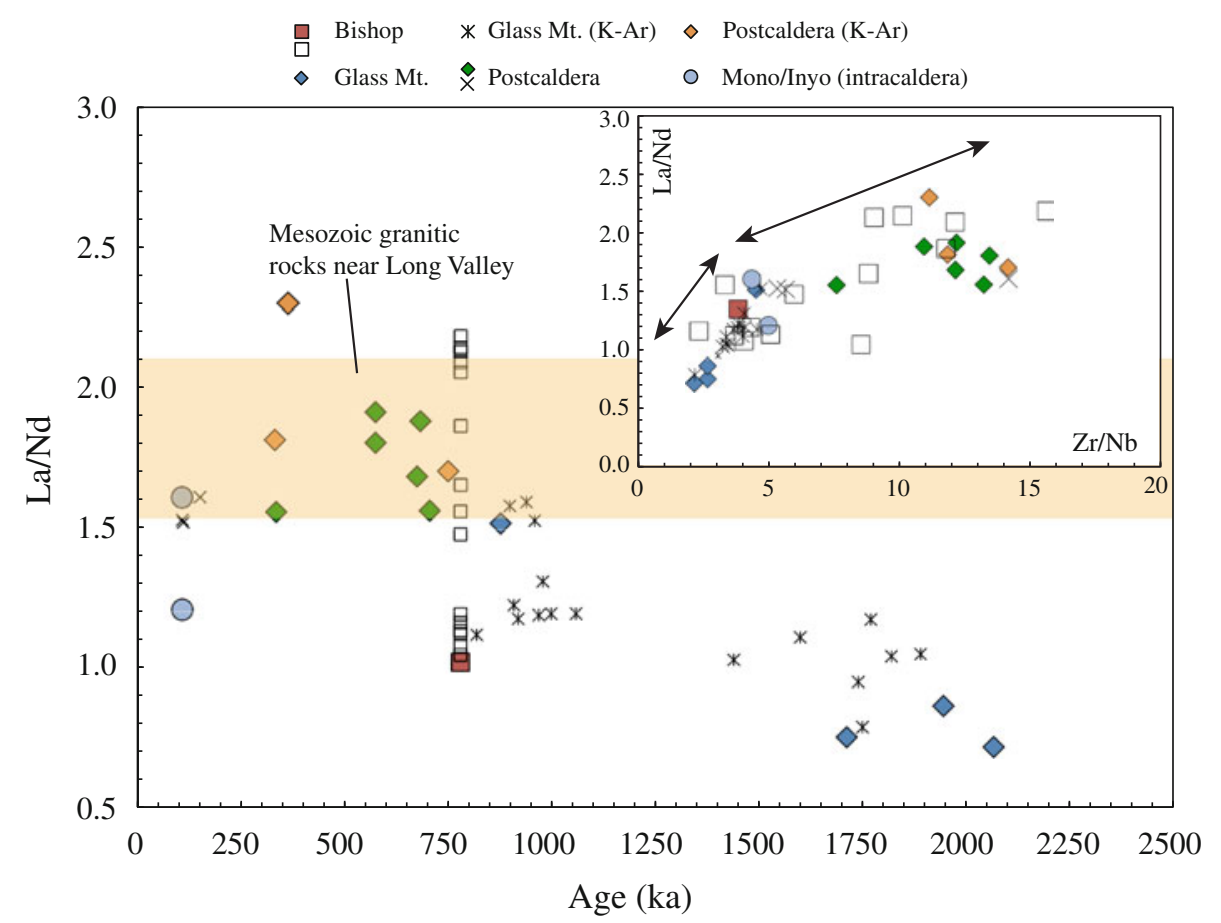

\section{The thermal evolution of Long Valley magma reservoir(s)}

Knowledge of the thermal evolution of the Long Valley magma system, in particular the supervolcanic Bishop Tuff magma(s), has important physical implications for understanding the evolution of its volcanic behavior. Eruption temperatures (i.e., derived from coexisting $\mathrm{Fe}-\mathrm{Ti}$ oxide pairs) are expected to be equal to or less than crystallization temperatures, although reversals are reported elsewhere (e.g., Simon et al. 2009). In general, there are limitations to establishing a robust geothermometry based on coexisting mineral assemblages for Long Valley rhyolites (e.g., Evans and Bachmann, 2013), in part because of the crystal-poor nature of the rocks, the possible exceptions being the Bishop Tuff (Hildreth 1977) and a short list of precaldera rhyolites (Metz and Mahood 1991). Here, we focus on zircon saturation temperatures $\left(\mathrm{T}_{\mathrm{Zr}}\right)$ that we calculated from whole rock compositions and $\mathrm{Zr}$ contents of the studied rhyolites following the approach of Watson and Harrison (1983) and the recalibration by Boehnke et al. (2013) (Fig. 10). Additional magma temperature estimates come from oxygen isotope thermometry (Chiba et al. 1989), Tiin-zircon (Watson et al. 2006), and Ti-in-quartz (Wark and Watson 2006) geothermometers. Using the new calibration of Boehnke et al. (2013), the $\mathrm{T}_{\mathrm{Zr}}$ for Bishop Tuff pumice $(\sim$ melt) compositions that range continuously from $\sim 665$ to $750{ }^{\circ} \mathrm{C}$ with a median of $695{ }^{\circ} \mathrm{C}(n=424)$ (Hildreth and Wilson 2007) is significantly lower than those estimated from Ti-in-quartz (720-810 ${ }^{\circ} \mathrm{C}$, Wark et al. 2007), oxygen $\Delta^{18} \mathrm{O}$ (qz-mt) fractionation $\left(715-815^{\circ} \mathrm{C}\right.$, Bindeman and
Valley 2002), and eruption temperatures derived from $\mathrm{Fe}-$ Ti oxide pairs $\left(714-798{ }^{\circ} \mathrm{C}\right.$, Hildreth and Wilson 2007). The lower zircon saturation and higher eruption temperatures resulting from these different geothermometers are surprising given the geological processes that they are conventionally thought to reflect (i.e., zircon crystallization and near-eruption melt temperature, respectively). Based on the thermodynamic analysis of Ghiorso and Gualda (2012), the titania activity derived from $\mathrm{Fe}-\mathrm{Ti}$ oxide pairs reported for the Bishop Tuff is orthogonal to the trend expected of oxide-melt equilibrium upon cooing of a magmatic system. Ghiorso and Gualda (2012) therefore suggested that the $\mathrm{Fe}-$ Ti oxide temperature estimates for the Bishop Tuff likely do not record preeruptive conditions (i.e., near-eruption temperatures), but rather may imply reequilibration. In addition, Reid et al. (2011) find that the apparent Ti-in-zircon crystallization temperatures determined for the Bishop Tuff are more restricted $\left(\Delta T \sim 30-40{ }^{\circ} \mathrm{C}\right)$ and more similar $\left(<720{ }^{\circ} \mathrm{C}\right)$ to the recalibrated zircon saturation temperature estimates. The similarity between a majority of the zircon saturation temperatures and the Ti-in-zircon crystallization temperatures is increased if realistic pressure corrections are included in the Ti-in-zircon calculations. Moreover, because of recent evidence for enhanced solubility of $\mathrm{Ti}$ in quartz at upper crustal pressures (Thomas et al. 2010), the reported Ti-in-quartz temperature estimates may also be too high (Reid et al. 2011). Collectively, a limited range of zircon temperatures is more consistent with the idea that the Bishop Tuff was derived primarily from remelted subvolcanic intrusions by the recharge of hotter magmas rather than from a long-lived, cooling, and evolving magma body. 


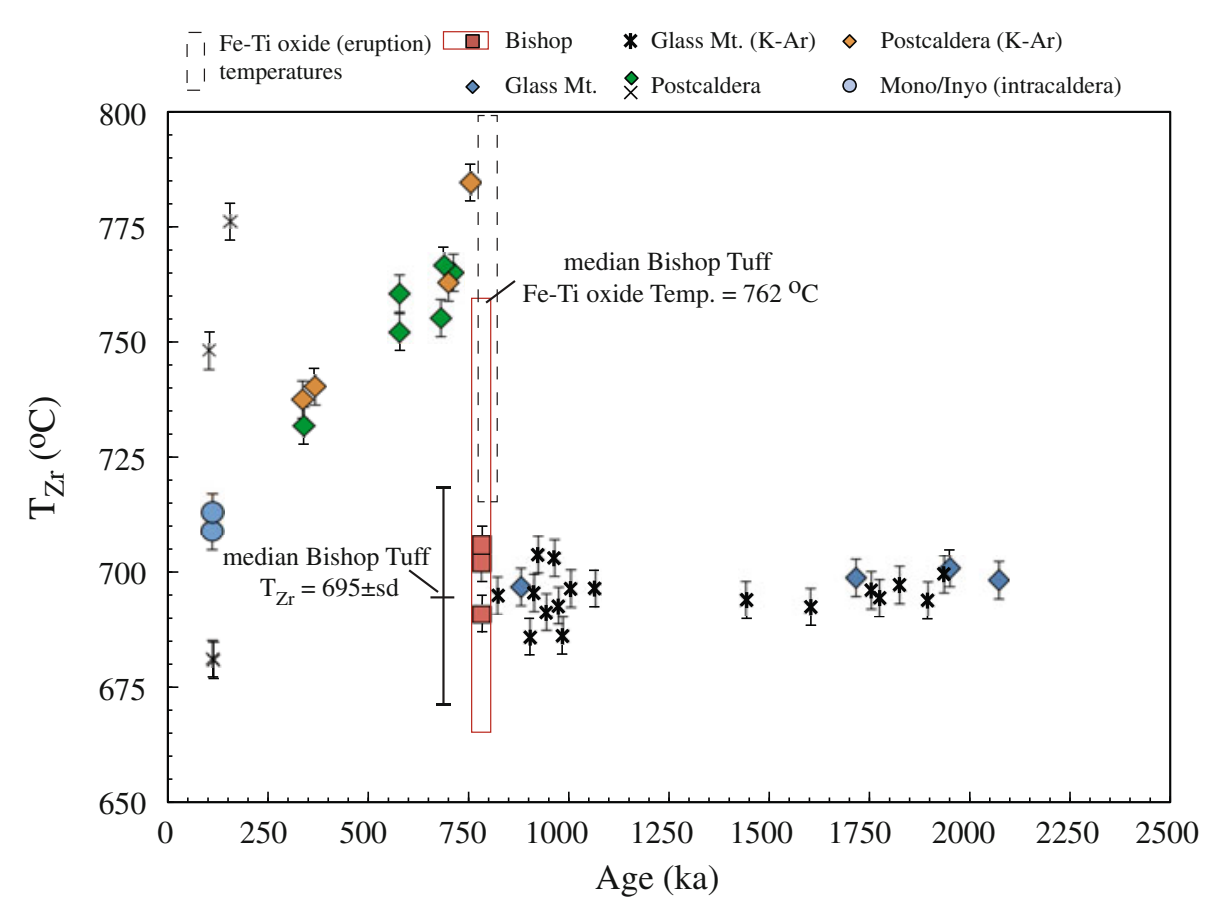

Fig. 10 Calculated zircon saturation temperatures $\left(\mathrm{T}_{\mathrm{Zr}}\right)$ versus eruption age (ka) for Long Valley rhyolites (using calibration of Boehnke et al. 2013). Sample symbols shown in legend. Temperature estimates may be incorrect if melts include unsupported $\mathrm{Zr}$ contents via assimilation (see text). Median calculated $\mathrm{T}_{\mathrm{Zr}}$ shown for Bishop Tuff pumice of Hildreth and Wilson (2007) is similar to that of all

Moreover, remelting of solidified intrusions, rather than remobilization of a consolidated crystal mush, is our preferred interpretation because of the apparent lack of zircon carryover from the precaldera rhyolites and the evidence for assimilation of young hydrothermally altered intrusions reported by Schmitt and Simon (2004).

The zircon solubility model of Watson and Harrison (1983) was primarily envisioned to address the question of how effectively eutectic granitic melts would dissolve inherited zircon and to understand the redistribution of geochemically interesting elements contained in zircon $(\mathrm{Zr}$, $\mathrm{Hf}, \mathrm{U}, \mathrm{Th}, \mathrm{REE}$, etc.) and not strictly speaking for thermometery. It is therefore useful to consider the implications of contrasting $\mathrm{T}_{\mathrm{Zr}}$ in Long Valley magmas, ranging from precaldera magmas with relatively constant apparent $\mathrm{T}_{\mathrm{Zr}}$ or $\mathrm{Zr}$ contents $(\sim 90-100 \mathrm{ppm}$, this study), to the extreme range observed in the Bishop Tuff ( $\sim 75-240 \mathrm{ppm})$ and a prominent decline with time in the postcaldera rhyolites (from $\sim 200 \mathrm{ppm}$ dropping progressively to precaldera levels) shown in Fig. 10. Of interest is the fact that many pumice from the Bishop Tuff have $\mathrm{Zr}$ contents similar to those found in the precaldera magmas (mean $=101 \mathrm{ppm}$, median $=94 \mathrm{ppm}, n=424$; Hildreth and Wilson, 2007). This common $\mathrm{Zr}$ content equates to a zircon saturation temperature $\left(\mathrm{T}_{\mathrm{Zr}}\right)$ of $\sim 700{ }^{\circ} \mathrm{C}$ about the same as all of the precaldera rhyolites (Fig. 10), begging the question of precaldera rhyolites. Relative $\mathrm{T}_{\mathrm{Zr}}$ are negligibly effected by the new calibration, but are about $50^{\circ}$ lower than with the calibration of Watson and Harrison (1983). Errors reflect analytical uncertainties. Eruption temperatures for Bishop Tuff samples using Fe-Ti oxide geothermometry are shown for comparison (Hildreth 1977; Hildreth and Wilson 2007), dashed box slightly offset in age for clarity

whether the $\mathrm{T}_{\mathrm{Zr}}$ estimates largely reflect a melting process (i.e., made up primarily of new magma via melting of young subvolcanic intrusions)? Zircon-undersaturated or oversaturated melts would likely yield more variability in $\mathrm{Zr}$ contents, perhaps like the compositions found among the more extreme Bishop Tuff pumice and postcaldera rhyolites (Hildreth and Wilson 2007). The apparent $\mathrm{T}_{\mathrm{Zr}}$ maximum found in the earliest postcaldera rhyolites likely reflects recharge from a less evolved melt and/or crustal contamination rather than simply a peak in temperature (cf. Claiborne et al. 2006). Remelting of previously intruded young granitic intrusions (albeit where sometimes melt collected and resided in the crust for protracted times), by injection of more primitive possibly hotter (but not necessarily all mafic) melts, appears to be the best explanation for the initially constant $\mathrm{T}_{\mathrm{Zr}}$ values followed by the secular decreasing $\mathrm{T}_{\mathrm{Zr}}$ trend found among the postcaldera rhyolites.

\section{Conceptual model for the Long Valley magma reservoir through time}

The magmatic plumbing system for Long Valley caldera has been conceptualized by a number of studies (e.g., Hildreth 2004 and references therein). Evidence for low velocity zones are reported, but most geophysical surveys reveal little 


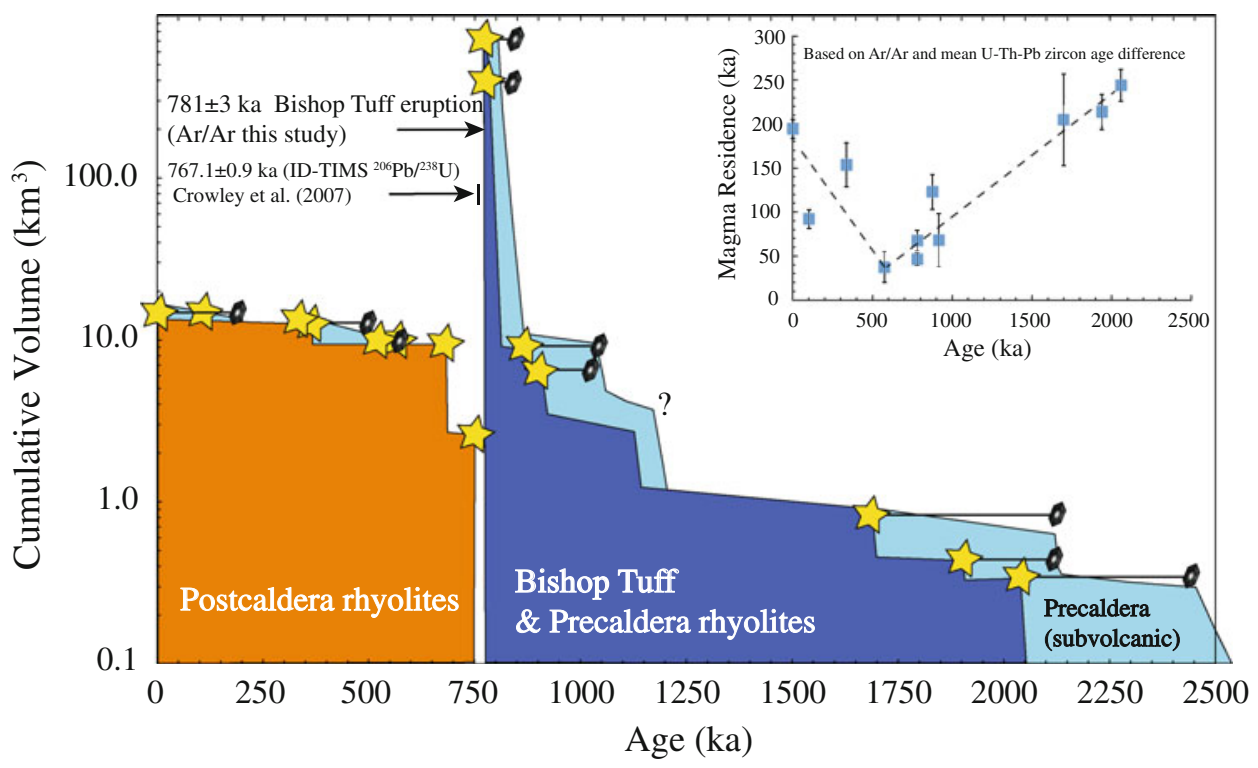

Fig. 11 Cumulative volume $\left(\mathrm{km}^{3}\right)$ of rhyolite eruptions versus age (ka). Volume rescaled after the Bishop Tuff eruption to emphasize the large size of early postcaldera rhyolites. Light blue areas represent unerupted magma (residence). Yellow stars indicate eruption age of studied rhyolites. Length of horizontal line, connecting zircon symbol to eruption, indicates span of zircon ages measured in the studied rhyolites (Simon and Reid 2005; Simon et al. 2007; this study). Inset shows inferred magma residence based on difference between $\mathrm{Ar} / \mathrm{Ar}$ eruption age and mean $\mathrm{U}-\mathrm{Th}-\mathrm{Pb}$ zircon age for each studied rhyolite.
Eruptions with the greatest volume coincide with the period in time where rhyolites exhibit the shortest magma residence (i.e., Bishop Tuff and early postcaldera rhyolites), implying rapid production. Volume estimates derived from areal measurements and dome thicknesses (approximated by contour intervals) from maps of Bailey et al. (1976); Metz and Bailey (1993) and the approximately equal proportions of fall versus flow deposits of the $>750 \mathrm{~km}^{3}$ Bishop Tuff (Hildreth and Mahood 1986; Wilson and Hildreth 1997)

used to infer (at least qualitatively) the nature of the magma reservoir. In theory, the combination of isotopic and geochemical tracers with high precision geochronology affords the timing of the general features of the magma system (e.g., input, differentiation, and storage times scales).

Silicic extrusions at Long Valley display relatively short term (10's-100's ka) and possibly cyclic, isotopic, and geochemical fluctuations which are thought to result from changes in the composition of the parental magmas delivered to the active chamber(s) (Christensen and Halliday 1996; Davies and Halliday 1998; Halliday et al. 1984; Simon et al. 2007; this study). Broad shifts in $\varepsilon_{\mathrm{Nd}}$ and $\varepsilon_{\mathrm{Hf}}$ over time periods of 100's ka exist, but likely formed more rapidly (10's ka) as indicated by the $\varepsilon_{\mathrm{Nd}}$ (e.g., Christensen and DePaolo 1993; Halliday et al. 1984) and $\varepsilon_{\mathrm{Hf}}$ (this study) heterogeneity found within their crystal populations. Of particular interest is the fact that these isotopic (i.e., $\mathrm{Nd}, \mathrm{Hf}$, and $\mathrm{Pb}$ ) and geochemical (e.g., $\mathrm{La} / \mathrm{Nd}$ and $\mathrm{La} / \mathrm{Nb}$ ) signatures indicative of a greater crustal component appear to correlate with magma residence times during precaldera, caldera, and late postcaldera time (Fig. 11), but appear uncorrelated starting after eruption of the Bishop Tuff and continuing on for $\sim 400 \mathrm{ka}$ (inset Fig. 11). We envision a magma plumbing system dominantly comprised of hot but consolidated young silicic intrusions, which were remelted, and remobilized when mantle-derived 
basaltic magma and occasional more evolved deep crustal magmas were intruded (Fig. 12). This volcanic system had mushy magma chambers and highly fractionated melts that intermittently resided in the crust for 10's-100's ka. Thus, some aspects of the data are consistent with both the mush (Hildreth and Wilson 2007) and the incremental pluton buildup (Glazner et al. 2004) models. Furthermore, the data are also consistent with suggestions made by Sparks et al. (1990) that the extrusion of rhyolite coincided with episodic influxes of mafic magmas into these young granitoids causing them to melt and erupt at the surface as rhyolitic lavas and pyroclastic flows.

\section{Periods of the Long Valley Magma system as defined by chronology, isotopic signatures, and geochemical trends}

2.5-0.8 Ma Glass Mountain rhyolites: They reflect formation of an extensive shallow magma system with transient melt bodies through incremental emplacement of evolved magmas from the mid- to lower crust that is later recharged by more mafic influx.

During this period, evolved magmas were emplaced and then crystallized extensively in the shallow crust. At various times, highly evolved crystal-poor melt coalesced to form a nested complex (i.e., made of discrete melt pockets in magma mush, Hildreth and Wilson 2007). Thermally insolated, some of these magmas resided for protracted time periods (10's-100's ka) before solidifying to form young intrusive bodies or erupting as the precaldera rhyolites. Eruptions may have been triggered by emplacement of mantle-derived mafic magmas into the base of the complex, whose unerupted magmas ultimately solidified to form a complex of young subvolcanic intrusions. These were then at least partially remelted by later magma recharge to produce younger rhyolites (also see below). This interpretation is supported in part by boron isotopic evidence contained in precaldera rhyolites (and more strongly so in the postcaldera rhyolites) implying that they assimilated some hydrothermally altered material that was virtually indistinguishable from the rhyolites themselves (Schmitt and Simon 2004). Earlier extrusions tend to exhibit the greatest crustal component with their lower $\mathrm{Nd}$ and $\mathrm{Hf}$ isotope compositions $\left(\varepsilon_{\mathrm{Nd}} \leq-2.5\right.$ and $\left.\varepsilon_{\mathrm{Hf}} \leq 0\right)$, which may reflect auto-assimilation of marginally older (100's ka) intrusive bodies perhaps because they were generated first. At the same time, the increased record of crustal contamination may also reflect the longer time periods that early magmas spent residing in the crust (Simon et al. 2007).

0.85-0.78 Ma Bishop Tuff: It reflects rapid rhyolite magma production through remelting of an admixture of
Glass Mountain-aged intrusions and mantle-derived magma due to an increase in more primitive magma influx.

To explain the lack of Glass Mountain-aged crystals, relatively lower zircon saturation and Ti-in-zircon crystallization temperatures as compared to the $\mathrm{Fe}-\mathrm{Ti}$ oxide temperatures, large volume, and greater mantle isotopic signatures $\left(\varepsilon_{\mathrm{Nd}} \sim-1.5\right.$ to -1.0 and $\left.\varepsilon_{\mathrm{Hf}} \sim 1.5-2.5\right)$ in the Bishop Tuff, we hypothesize that production of the Bishop Tuff reflects a relatively high rate of mantlederived mafic input into the shallow crust that melted Pleistocene intrusions. The influence of mafic recharge would have begun possibly as early as $\sim 1 \mathrm{Ma}$ with remelting pre-Bishop $(\sim 3.5-1.0 \mathrm{Ma})$ granitic intrusions, contributing to the expansion and coalescence of the Bishop magma chamber and may have also produced some of the youngest precaldera rhyolites. This is broadly similar to the suggestion of Mahood (1990) but rather than small degrees of assimilation we are suggesting that the erupted Bishop Tuff magma was largely derived from remelting young granitic intrusions (cf. Sparks et al. 1990). Minor amounts of Mesozoic zircon has been observed in the Bishop Tuff $(<2-4 \%)$, but never in any of the other rhyolites (Simon and Reid 2005), which may be explained by the expanding system, but might alternatively be related the magnitude of the eruption itself. This general scenario helps to explain the diversity of Bishop Tuff magma compositions. In particular, it can explain the compositional and isotopic similarity among the precaldera magmas and the Bishop Tuff, but at the same time their distinct crystal populations. This model explains the zoning in the Bishop Tuff as an admixture of melts from young intrusive bodies where the mantle influx provides the thermal input that elevates the temperature of the system. Once melting began, the early Bishop Tuff was formed from partial remelting of more fusible intrusions and the less evolved late erupting Bishop Tuff formed from less fusible material assimilated during the peak period of recharge and temperature influx. As has been well documented by Hildreth (1977), the compositional zonation of the Bishop Tuff existed prior to its crystallization (cf. Gualda and Ghiorso 2013). Our model can explain a progressively zoned extrusion produced from the co-eruption of two or more magma bodies (via melting of intrusions including but more diverse (cf. Hildreth and Wilson 2007) than compositions exhibited by the precaldera Older and Younger Glass Mountain rhyolites). Once formed the magmas underwent minimal crystallization prior to eruption, which lessens the need for the requirement of 50-75\% crystallization of a low silica rhyolitic precursor (Hildreth 1977). It can also explain the near lack of evidence for crystal accumulation. This is quite distinct from the standard magma chamber 
Fig. 12 Conceptual schematic time series illustrating representative NE-SW crosssections for the history of the Long Valley magma system. Major events are labeled in figure and include: (1) gradual formation of a complex of shallow granitic intrusions, (2) eruption of precaldera Older Glass Mountain rhyolites from transient magma bodies with relatively long magma residence times ( 200-250 ka), (3) hiatus in extrusive and magmatic records indicating solidified or nearly solidified system with little magmatic activity, (4) expansion of complex through additional intrusions, $(\mathbf{5})$ eruption of precaldera Younger Glass Mountain rhyolites from transient magma bodies, partially overlapping in time with, (6) rapidly generated Bishop Tuff magmas through remelting of relatively diverse precaldera granitic intrusions, (7) caldera collapse and eruption of the Bishop Tuff, (8) eruption of early postcaldera rhyolites from transient melt bodies that potentially had a new component of crust (possibly due to assimilation of Mesozoic country rock), (9) eruption of late postcaldera moat rhyolites from transient magma bodies that initially had a higher component of mantlederived source material, but later on exhibit more typical isotopic signatures and longer crustal residence times $(\geq 100 \mathrm{ka})$, and (10) eruption of Inyo Domes and other rhyodacites including those of Mammoth Mountain; and possibly a return to a subvolcanic environment similar to that of the early precaldera system

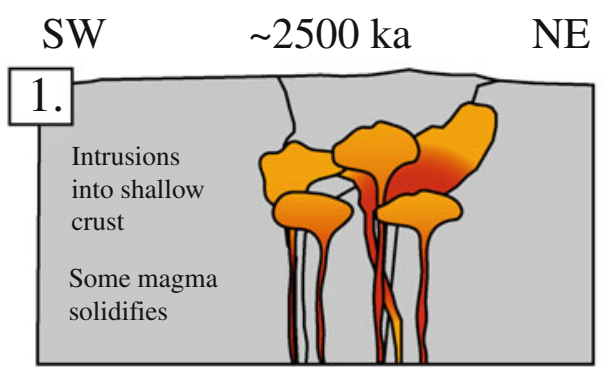

2400-1700 ka Older Glass Mt.

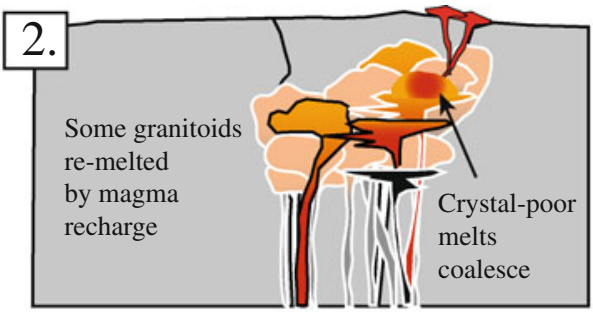

1700-1200 ka little magma

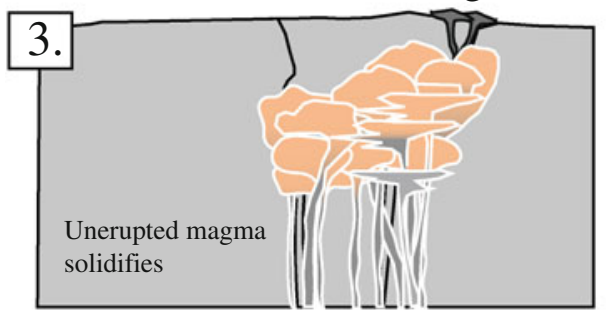

\section{0-1100 ka expansion of GM}

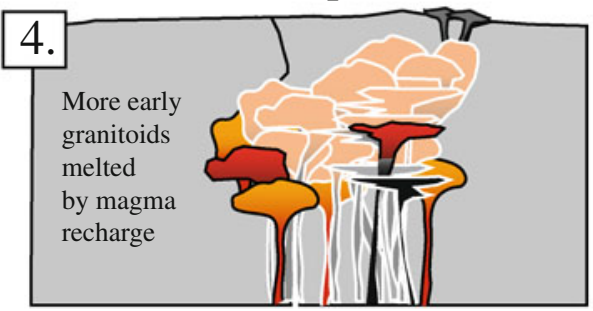

1100-800 ka Younger Glass Mt.
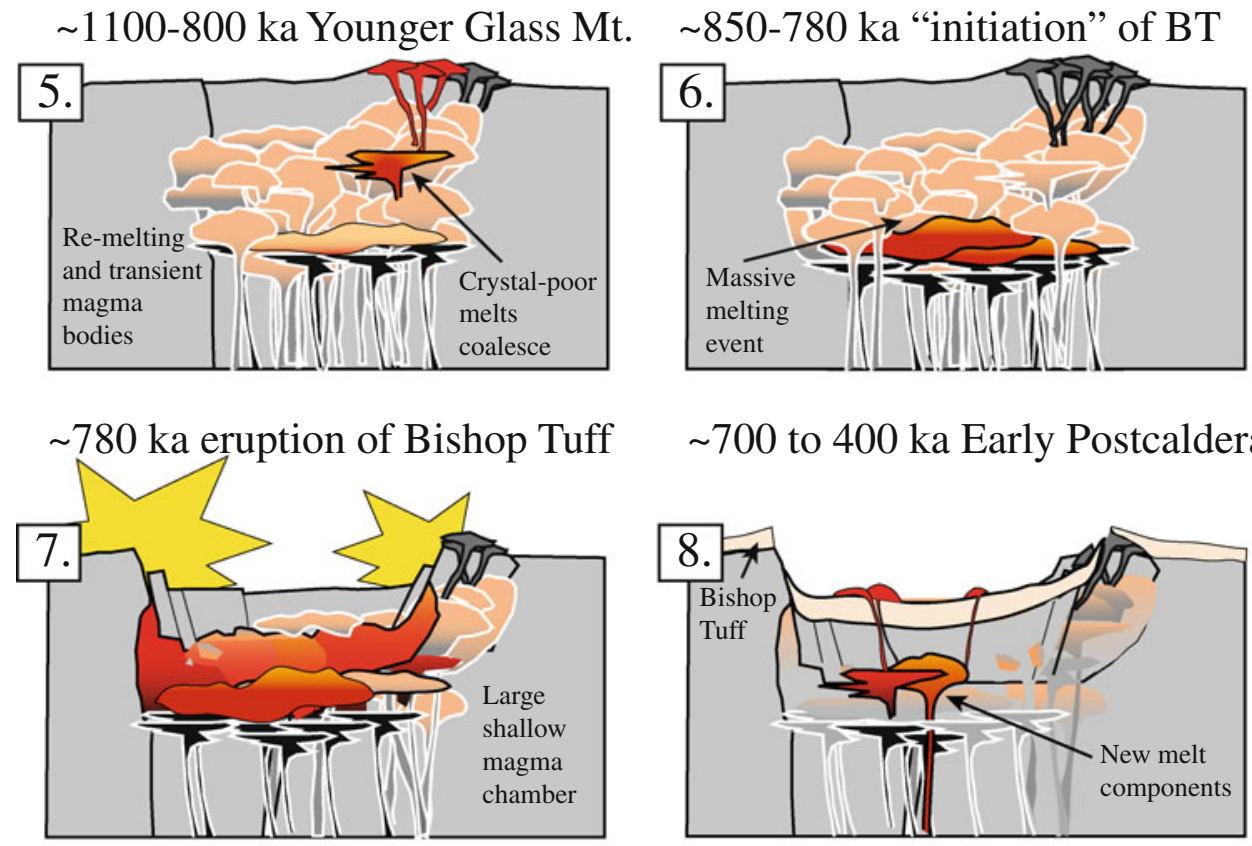

700 to 400 ka Early Postcaldera

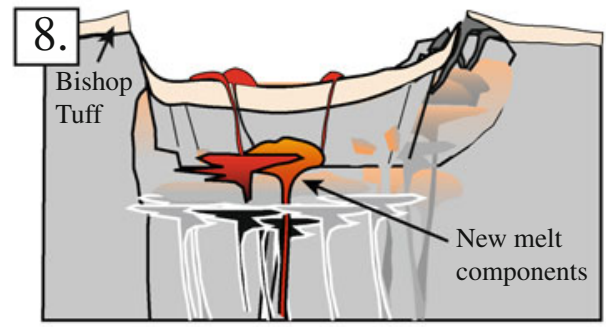

400 to 100 ka Late Postcaldera

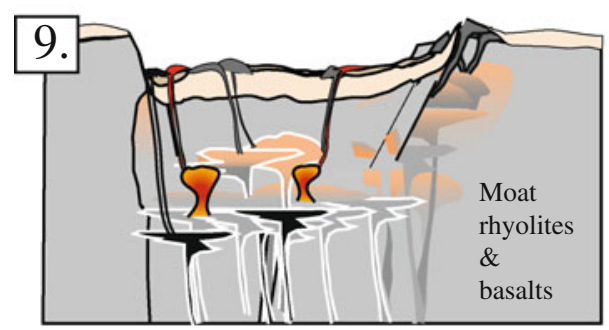

$\sim 100$ ka to Present day

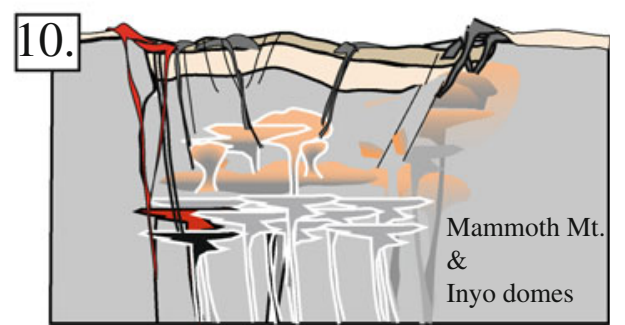

model where the zoning reflects inversion of a long-lived integrated stratigraphically zoned magma body (cf. Hildreth 1977; Hildreth and Wilson 2007; Wallace et al. 1999).
0.7-0.4 Ma early postcaldera rhyolites: They reflect addition of a new less evolved magma component or the exhaustion of Pleistocene intrusions (potentially leading to 
assimilation of some Mesozoic crust) to predominately mantle-derived magmas.

In early postcaldera time, the eruptions once again exhibit more crustal $\mathrm{Nd}$ and $\mathrm{Hf}$ isotope compositions ( $\varepsilon_{\mathrm{Nd}} \leq-2.5$ to -2.0 and $\varepsilon_{\mathrm{Hf}} \sim 1.0-1.5$ ). Within the first $\sim 400 \mathrm{ka}$ after eruption of the Bishop Tuff, the rhyolite compositions imply that there was input of a new geochemical component (possibly input of less evolved magma to explain the higher apparent $\mathrm{T}_{\mathrm{Zr}}$ and distinct $\mathrm{REE}$ signatures). Alternatively, the major period of magma chamber growth, leading to caldera collapse and the Bishop Tuff, could have effectively consumed all of the Pleistocene intrusions and therefore led to some Mesozoic country rock assimilation. Although the data do not provide a unique solution, both scenarios are consistent with the short to negligible preeruption zircon age spans and the diversity of Hf zircon isotope compositions observed in the $676 \mathrm{ka}$ MLV26 rhyolite. Of particular importance is the zircon measurement contained in MLV26 that yielded a negative $\varepsilon_{\mathrm{Hf}}$ value that is more crustal than all of the studied precaldera Glass Mountain rhyolite compositions.

0.4 to $\sim 0.1$ Ma late postcaldera rhyolites: They reflect waning mantle and thermal input into the crust and return to precaldera conditions.

The late postcaldera stage initiates with the eruption of the $336 \mathrm{ka}$ Hot Creek flow which reflects rhyolite magma generation with the greatest mantle signatures $\left(\varepsilon_{\mathrm{Nd}} \sim-1.0\right.$ and $\varepsilon_{\mathrm{Hf}} \sim 2.5$ ) in the entire evolution of the Long Valley system. This may be because contributions from young intrusions were exhausted by previous rhyolite generation and/or because lower recharge rates decreased the ambient crustal temperatures such that assimilation of shallow crust was no longer favored. From $\sim 0.4$ Ma until extrusion of the $\sim 0.1$ Ma Deer Mountain rhyolite, the activity and mantle influx to the volcanic system appeared to wane, eruptions become less voluminous, and the younger extrusions again had greater crustal affinities. The record of greater crustal contamination, like that exhibited by the oldest precaldera rhyolites, may reflect the magma residence time in the crust prior to extrusion (Simon et al. 2007).

\section{Conclusions}

At Long Valley rhyolites stored in the shallow crust appear to have been generated by a varying mixture of crustal and mantle reservoirs. The compositions and nature of the extrusions reflect these mixtures and apparently their magma residence time. Precaldera rhyolites and the caldera-related Bishop Tuff appear to reflect a secular increase in the role of mantle-derived material diluting the crustal signal. In contrast, increases in $\varepsilon_{\mathrm{Hf}}$ and $\varepsilon_{\mathrm{Nd}}$ among postcaldera rhyolites appear uncorrelated with eruption size and imply a new generation of rhyolitic magma. A diminishing input of crustal assimilants is recorded by Hf isotopes in zircon and whole rocks that may have been the result of an extensive period of prior rhyolite generation that depleted the local crust. The isotopic variations likely also reflect changes in the rate of injection of primitive basaltic magma into the base of the volcanic system. Shifts in the composition of crustal magma sources may have also played a role. We envision a magma plumbing system dominantly comprised of hot but consolidated young silicic intrusive bodies, which were remelted and remobilized when mantlederived basaltic magma and occasional more evolved deep crustal magmas were intruded. This volcanic system had mushy magma chambers and highly fractionated melts that intermittently resided in the crust for 10's-100's ka.

Given the relatively short time intervals measured between preeruption crystallization and eruption ages, we suggest that some rhyolite magmas at Long Valley were produced rapidly. Over the time scales (10's to $>100$ 's ka) relevant to continental silicic magma systems, the high precision dating of rhyolites at Long Valley helps to answer two fundamental questions: (1) "How long it takes to build a volcanic system capable of a supervolcanic eruption?" and (2) "How long it takes to produce a supereruption." At Long Valley caldera, it appears to have taken a million years or more to prime a crustal volume for supervolcanic magma accumulations, but once it was sufficiently heated and infused with evolved, easily fused intrusive rocks the time span to ultimately assemble 100's of $\mathrm{km}^{3}$ of rhyolite magma occurred much more rapidly, by at least an order of magnitude-not those predicted by global repose interval models.

Acknowledgments We value the technical assistance of J. Barling, T. Becker, S. Brown, R. Friedman, B. Kieffer, and T. Owens. Informal reviews by R. Mills and M. Tappa are greatly appreciated. This contribution benefits from two anonymous reviewers and the efforts of AE T. Grove. The ion microprobe facility at UCLA is partly supported by a grant from the Instrumentation and Facilities Program, Division of Earth Sciences, National Science Foundation.

Open Access This article is distributed under the terms of the Creative Commons Attribution License which permits any use, distribution, and reproduction in any medium, provided the original author(s) and the source are credited.

\section{References}

Anderson AT, Davis AM, Lu FQ (2000) Evolution of Bishop Tuff rhyolitic magma based on melt and magnetite inclusions and zoned phenocrysts. J Petrol 41:449-473

Annen C (2009) From plutons to magma chambers: thermal constraints on the accumulation of eruptible silicic magma in the upper crust. Earth Planet Sci Lett 284:409-416 
Bachmann O, Bergantz GW (2004) On the origin of crystal-poor rhyolites: extracted from batholithic crystal mushes. J Petrol 45:1565-1582

Bachmann O, Miller CF, De Silva SL (2007) The volcanic-plutonic connection as a stage for understanding crustal magmatism. J Volcanol Geotherm Res 167:1-23

Bacon CR, Lowenstern JB (2005) Late Pleistocene granodiorite source for recycled zircon and phenocrysts in rhyodacite lava at Crater Lake, Oregon. Earth Planet Sci Lett 233:277-293

Bailey RA (1989) Geologic map of the Long Valley Caldera, MonoInyo Craters Volcanic Chain, Eastern California, miscellaneous investigations series I-1933

Bailey RA, Dalrymple GB, Lanphere MA (1976) Volcanism, structure, and geochronology of Long-Valley Caldera, MonoCounty, California. J Geophys Res 81:725-744

Bindeman IN, Valley JW (2002) Oxygen isotope study of the Long Valley magma system, California: isotope thermometry and convection in large silicic magma bodies. Contrib Mineral Petrol 144:185-205

Boehnke P, Watson EB, Trail D, Harrison TM, Schmitt AK (2013) Zircon saturation re-revisited. Chem Geol 351:324-334

Bryce JG, DePaolo DJ, Lassiter JC (2005) Geochemical structure of the Hawaiian plume: $\mathrm{Sr}, \mathrm{Nd}$, and $\mathrm{Os}$ isotopes in the $2.8 \mathrm{~km}$ HSDP-2 section of Mauna Kea volcano. Geochem Geophys Geosyst 6:1-36

Burnham AD, Berry AJ (2012) An experimental study of trace element partitioning between zircon and melt as a function of oxygen fugacity. Geochim Cosmochim Acta 95:196-212

Channell JET, Hodell DA, Singer BS, Xuan C (2010) Reconciling astrochronological and ${ }^{40} \mathrm{Ar} /{ }^{39} \mathrm{Ar}$ ages for the Matuyama-Brunhes boundary and late Matuyama Chron. Geochem Geophys Geosyst 11:Q0AA12. doi:10.1029/2010GC003203

Charlier BLA, Wilson CJN, Lowenstern JB, Blake S, Van Calsteren PW, Davidson JP (2005) Magma generation at a large, hyperactive silicic volcano (Taupo, New Zealand) revealed by U-Th and U-Pb systematics in zircons. J Petrol 46:3-32

Chiba H, Chacko T, Clayton RN, Goldsmith JR (1989) Oxygen isotope fractionations involving diopside, forsterite, magnetite, and calcite-application to geothermometry. Geochim Cosmochim Acta 53:2985-2995

Christensen JN, DePaolo DJ (1993) Time scales of large volume silicic magma systems-Sr isotopic systematics of phenocrysts and glass from the Bishop Tuff, Long Valley, California. Contrib Mineral Petrol 113:100-114

Christensen JN, Halliday AN (1996) Rb-Sr ages and Nd isotopic compositions of melt inclusions from the Bishop Tuff and the generation of silicic magma. Earth Planet Sci Lett 144:547-561

Claiborne LL, Miller CF, Walker BA, Wooden JL, Mazdab FK, Bea $\mathrm{R}$ (2006) Tracking magmatic processes through $\mathrm{Zr} / \mathrm{Hf}$ ratios in rocks and $\mathrm{Hf}$ and Ti zoning in zircons: an example from the spirit mountain Batholith, Nevada. Mineral Mag 70:517-543

Coleman DS, Gray W, Glazner AF (2004) Rethinking the emplacement and evolution of zoned plutons: geochronologic evidence for incremental assembly of the Tuolumne Intrusive Suite, California. Geology 32:433-436

Crisp JA (1984) Rates of magma emplacement and volcanic output. J Volcanol Geotherm Res 20:177-211

Crowley JL, Schoene B, Bowring SA (2007) U-Pb dating of zircon in the Bishop Tuff at the millennial scale. Geology 35:1123-1126

Davies GR, Halliday AN (1998) Development of the Long Valley rhyolitic magma system: strontium and neodymium isotope evidence from glasses and individual phenocrysts. Geochim Cosmochim Acta 62:3561-3574

Davies GR, Halliday AN, Mahood GA, Hall CM (1994) Isotopic constraints on the production-rates, crystallization histories and residence times of Pre-Caldera Silic Magmas, Long Valley, California. Earth Planet Sci Lett 125:17-37

Davis JW, Coleman DS, Gracely JT, Gaschnig R, Sterns M (2012) Magma accumulation rates and thermal histories of plutons of the Sierra Nevada batholith, CA. Contrib Mineral Petrol 163:449-465

DePaolo DJ (1978) Study of magma sources, mantle structure and the differentiation of the earth from variations of Nd-143/Nd-144 in igneous rocks, geology. California Institute of Technology, Pasadena, p 360

DePaolo DJ (1988) Neodymium isotope geochemistry. Springer, Berlin

DePaolo DJ, Perry FV, Baldridge WS (1992) Crustal versus mantle sources of granitic magmas: a two-parameter model based on $\mathrm{Nd}$ isotopic studies. Earth Sci Trans R Soc Edinb 83:439-446

Druitt TH, Costa F, Deloule E, Dungan M, Scaillet B (2012) Decadal to monthly timescales of magma transfer and reservoir growth at a caldera volcano. Nature 482:77-80

Dufek J, Bergantz GW (2005) Lower crustal magma genesis and preservation: a stochastic framework for the evaluation of basaltcrust interaction. J Petrol 46:2167-2195

Evans BW, Bachmann O (2013) Implications of equilibrium and disequilibrium among crystal phases in the Bishop Tuff. Am Mineral 98:271-274

Ghiorso MS, Gualda GAR (2012) A method for estimating the activity of titania in magmatic liquids for the compositions of coexisting rhombohedral and cubic iron-titanium oxides. Contrib Mineral Petrol 165:73-81

Glazner AF, Bartley JM, Coleman DS, Gray W, Tayler RZ (2004) Are plutons assembled over millions of years by amalgamation from small magma chambers? GSA Today 14:4-11

Glazner AF, Coleman DS, Bartley JM (2008) The tenuous connection between high-silica rhyolites and granodiorite plutons. Geology 36:183-186

Goolaerts A, Mattielli N, de Jong J, Weis D, Scoates JS (2004) Hf and $\mathrm{Lu}$ isotopic reference values for the zircon standard 91500 by MC-ICP-MS. Chem Geol 206:1-9

Gualda GAR, Ghiorso MS (2013) The Bishop Tuff giant magma body: an alternative to the standard model. Contrib Mineral Petrol 166:755-775

Gualda GAR, Pamukcu AS, Ghiorso MS, Anderson AT, Sutton SR, Rivers ML (2012) Timescales of quartz crystallization and the longevity of the Bishop Giant Magma body. PLoS ONE 7:e37492

Halliday AN, Fallick AE, Hildreth W (1984) A Nd, Sr, and O isotopic investigation into the causes of chemical and isotopic zonation in the Bishop Tuff, California. Earth Plan Sci Lett 68:379-391

Halliday AN, Mahood GA, Holden P, Metz JM, Dempster TJ, Davidson JP (1989) Evidence for long residence times of Rhyolitic Magma in the Long Valley magmatic system-the isotopic record in Precaldera Lavas of Glass Mountain. Earth Planet Sci Lett 94:274-290

Hawkesworth CJ, George RM, Turner SP, Zellmer G (2004) Time scales of magmatic processes (Frontiers). Earth Planet Sci Lett 218:1-16

Hervig RL, Nelia DW (1992) Cause of chemical zoning in the Bishop (California) and Bandelier (New Mexico) magma chambers. Earth Planet Sci Lett 111:97-108

Heumann A, Davies GR (1997) Isotopic and chemical evolution of the post-caldera rhyolitic system at Long Valley, California. J Petrol 38:1661-1678

Heumann A, Davies GR, Elliott T (2002) Crystallization history of rhyolites at Long Valley, California, inferred from combined $\mathrm{U}$-series and $\mathrm{Rb}-\mathrm{Sr}$ isotope systematics. Geochim Cosmochim Acta 66:1821-1837 
Hildreth W (1977) The magma chamber of the Bishop Tuff: gradients in temperature, pressure, and composition, geology. University of California, Berkeley, p 328

Hildreth W (2004) Volcanological perspectives on Long Valley, Mammoth Mountain, and Mono Craters: several contiguous but discrete systems. J Volcanol Geotherm Res 136:169-198

Hildreth W, Mahood GA (1986) Ring-fracture eruption of the Bishop Tuff. Geol Soc Am Bull 97:396-403

Hildreth W, Wilson CJN (2007) Compositional zoning of the Bishop Tuff. J Petrol 48(5):951-999. doi:10.1093/petrology/ egm007

Johnson CM, Czamanske GK, Lipman PW (1989) Geochemistry of intrusive rocks associated with the Latir Volcanic field, NewMexico, and contrasts between evolution of Plutonic and Volcanic-Rocks. Contrib Mineral Petrol 103:90-109

Kemp AIS, Hawkesworth CJ, Foster GL, Paterson BA, Woodhead JD, Hergt JM, Gray CM, Whitehouse MJ (2007) Magmatic and crustal differentiation history of granitic rocks from Hf-O isotopes in zircon. Science 315:980-983

Krogh TE (1973) A low contamination method for hydrothermal decomposition of zircon and extraction of $\mathrm{U}$ and $\mathrm{Pb}$ for isotopic age determinations. Geochim Cosmochim Acta 37:485-494

Kuiper KF, Deino A, Hilgen FJ, Krijgsman W, Renne PR, Wijbrans JR (2008) Synchronizing rock clocks of Earth history. Science 320:500-504

Lees JM (2007) Seismic tomography of magmatic systems. J Volcanol Geotherm Res 167:37-56

Lipman PW (2007) Incremental assembly and prolonged consolidation of Cordilleran magma chambers: evidence from the Southern Rocky Mountain volcanic field. Geosphere 3:42-70

Mahood GA (1990) Evidence for long residence times of Rhyolitic Magma in the long valley magmatic system-the isotopic record in the Precaldera Lavas of Glass Mountain-Reply. Earth Planet Sci Lett 99:395-399

Mankinen EA, Gromme CS, Dalrymple GB, Lanphere MA, Bailey RA (1986) Paleomagnetism and K-Ar ages of volcanic-rocks from Long-Valley-Caldera, California. J Geophys Res Solid Earth Planets 91:633

Masturyono, McCaffrey R, Wark DA, Roecker SW, Fauzi, Ibrahim G, Sukhyar (2001) Distribution of magma beneath the Toba caldera complex north Sumatra Indonesia, constrained by threedimensional $P$ wave velocities, seismicity, and gravity data. Geochem Geophys Geosyst 2:1014. doi:10.1029/2000GC000096

Matzel JEP, Bowring SA, Miller RB (2006) Time scales of pluton construction at differing crustal levels: examples from the Mount Stuart and Tenpeak Intrusions, north Cascades, Washington. Geol Soc Am Bull 118:1412-1430

Metz J, Bailey RA (1993) Geologic map of Glass Mountain, miscellaneous investigations series I-1995

Metz JM, Mahood GA (1985) Precursors to the Bishop Tuff eruption-Glass Mountain, Long Valley, California. J Geophys Res Solid Earth Planets 90:1121-1126

Metz JM, Mahood GA (1991) Development of the Long Valley, California, Magma chamber recorded in Precaldera Rhyolite Lavas of Glass Mountain. Contrib Mineral Petrol 106:379-397

Michel J, Baumgartner L, Pulitz B, Schaltegger U, Ovtcharova M (2008) Incremental growth of the Patagonian Torres del Paine laccolith over 90 k.y. Geology 36:459-562

Miller CD (1985) Holocene eruptions at the Inyo volcanic chain, California: implications for possible eruptions in Long Valley Caldera. Geology 13:14-17

Mills RD, Coleman DS (2013) Temporal and chemical connections between plutons and ignimbrites from the Mount Princeton magmatic center. Contrib Mineral Petrol 165:961-980

Min KW, Mundil R, Renne PR, Ludwig KR (2000) A test for systematic errors in Ar-40/Ar-39 geochronology through comparison with $\mathrm{U} / \mathrm{Pb}$ analysis of a $1.1-\mathrm{Ga}$ rhyolite. Geochim Cosmochim Acta 64:73-98

Mundil R, Ludwig KR, Metcalfe I, Renne PR (2004) Age and timing of the Permain mass extinctions: $\mathrm{U} / \mathrm{Pb}$ dating of closed-system zircons. Science 305:1760-1763

Nomade S, Renne PR, Vogel N, Deino AL, Sharp WD, Becker TA, Jaouni AR, Mundil R (2005) Alder creek sanidine (ACs-2): a quaternary Ar-40/Ar-39 dating standard tied to the Cobb Mountain geomagnetic event. Chem Geol 218:315-338

Paces JB, Miller JD (1993) Precise U-Pb ages of duluth complex and related mafic intrusions, Northeastern Minnesota-geochronological insights to physical, petrogenetic, paleomagnetic, and tectonomagmatic processes associated with the $1.1 \mathrm{Ga}$ midcontinent rift system. J Geophys Res Solid Earth 98:13997-14013

Perry FV, DePaolo DJ, Baldridge WS (1993) Neodymium isotopic evidence for decreasing crustal contributions to Cenozoic ignimbrites of the western United States: implications for the thermal evolution of the Cordilleran crust. Geol Soc Am Bull 105:872-882

Pietruszka AJ, Garcia AJ (1999) The size and shape of Kilauea Volcano's summit magma storage reservoir: a geochemical probe. Earth Planet Sci Lett 167:311-320

Pretorius W, Weis D, Willams G, Hanano D, Kieffer B, Scoates JS (2006) Complete trace element characterization of granitoid (USGS G-2, GSP-2) reference materials by high resolution inductively coupled plasma-mass spectrometery. Geostand Geoanal Res 30:39-54

Reid MR (2003) Timescales of magma transfer and storage in the crust, treatise on geochemistry. Elsevier Ltd, Amsterdam, pp $167-187$

Reid MR (2008) How long does it take to supersize an eruption? Elements 4:23-28

Reid MR, Coath CD (2000) In situ U-Pb ages of zircons from the Bishop Tuff: no evidence for long crystal residence times. Geology 28:443-446

Reid MR, Coath CD, Harrison TM, McKeegan KD (1997) Prolonged residence times for the youngest rhyolites associated with Long Valley Caldera: Th-230-U-238 ion microprobe dating of young zircons. Earth Planet Sci Lett 150:27-39

Reid MR, Vazquez JA, Schmitt AK (2011) Zircon-scale insights into the history of a Supervolcano, Bishop Tuff, Long Valley, California, with implications for the Ti-in-zircon geothermometer. Contrib Mineral Petrol 161:293-311

Renne PR (2013) Some footnotes to the optimization-based calibration of the ${ }^{40} \mathrm{Ar} /{ }^{39} \mathrm{Ar}$ system, In: Jourdan F, Mark DF Verati C (eds) Advances in ${ }^{40} \mathrm{Ar} /{ }^{39} \mathrm{Ar}$ dating: From archeology to planetary science. Geological Society, London, Special Publications, 378. First published online July 2013, doi:10.1144/SP378.17

Renne PR, Swisher CC, Deino AL, Karner DB, Owens TL, DePaolo DJ (1998) Intercalibration of standards, absolute ages and uncertainties in 40Ar/39Ar dating. Chem Geol 145:117-152

Renne PR, Mundil R, Balco G, Min KW, Ludwig KR (2010) Joint determination of $40 \mathrm{~K}$ decay constants and $40 \mathrm{Ar} * / 40 \mathrm{~K}$ for the Fish Canyon sanidine standard, and improved accuracy for 40Ar/ 39Ar geochronology. Geochim Cosmochim Acta 74:5349-5367

Renne PR, Balco G, Ludwig KR, Mundil R, Min KW et al (2011) Response to the comment by W. H. Schwarz on "Joint determination of $40 \mathrm{~K}$ decay constants and $40 \mathrm{Ar} * / 40 \mathrm{~K}$ for the Fish Canyon sanidine standard, and improved accuracy for 40Ar/ 39Ar geochronology" by P.R. Renne et al. (2010). Geochim Cosmochim Acta 75:5097-5100

Rivera TA, Storey M, Zeeden C, Hilgen FJ, Kuiper K (2011) A refined astronomically calibrated $40 \mathrm{Ar} / 39 \mathrm{Ar}$ age for Fish Canyon sanidine. Earth Planet Sci Lett 311:420-426

Roberge J, Wallace PJ, Kent AJR (2013) Magmatic processes in the Bishop Tuff rhyolitiic magma based on trace elements in melt 
inclusions and pumice matrix glass. Contrib Mineral Petrol 165:237-257

Sañudo-Wilhelmy SA, Flegal AR (1994) Temporal variations in lead concentrations and isotopic composition in the Southern California Bight. Geochim Cosmochim Acta 58:3315-3320

Sarna-Wojcicki AM, Pringle MS, Wijbrans J (2000) New 40Ar/39Ar age of the Bishop Tuff from multiple sites and sediment rate calibration for the Matuyama-Brunhes boundary. J Geophys Res $105,21: 431-421,443$

Schärer U (1984) The effect of initial Th-230 disequilibrium on young U-Pb ages- the Makalu Case, Himalaya. Earth Planet Sci Lett 67:191-204

Schmitt AK, Simon JI (2004) Boron isotopic variations in hydrous rhyolitic melts: a case study from Long Valley, California. Contrib Mineral Petrol 146:590-605

Sherburn S, Bannister S, Bibby H (2003) Seismic velocity structure of the central Taupo volcanic zone, New Zealand, from local earthquake tomography. J Volcanol Geotherm Res 122:69-88

Simon JI, Reid MR (2005) The pace of rhyolite differentiation and storage in an 'archetypical' silicic magma system, Long Valley, California. Earth Planet Sci Lett 235:123-140

Simon JI, Reid MR, Young ED (2007) Lead isotopes by LA-MCICPMS: tracking the emergence of mantle signatures in an evolving silicic magma system. Geochim Cosmochim Acta 71:2014-2035

Simon JI, DePaolo DJ, Weis D, Renne PR, Mundil R (2008a) The temporal evolution of $\mathrm{Hf}$ and $\mathrm{Nd}$ isotopes of rhyolites from the Long Valley Caldera System, EOS Trans AGU, pp Abstract V23E-2168

Simon JI, Renne PR, Mundil R (2008b) Implications of pre-eruptive magmatic histories of zircons for U-Pb geochronology of silicic extrusions. Earth Planet Sci Lett 266:182-194

Simon JI, Vazquez JA, Renne PR, Schmitt AK, Bacon CR, Reid MR (2009) Accessory mineral U-Th-Pb ages and ${ }^{40} \mathrm{Ar} /{ }^{39} \mathrm{Ar}$ eruption chronology, and their bearing on rhyolitic magma evolution in the Pleistocene Coso volcanic field, California. Contrib Mineral Petrol 158(4):421-446

Smith RL (1979) Ash-flow magmatism. Geol Soc Am Spec Pap 180:5-27

Sparks RSJ, Huppert HE, Wilson CJN (1990) Comment on "evidence for long residence times of rhyolitic magma in the Long Valley magmatic system: the isotopic record in precaldera lavas of Glass Mountain" by A. N. Halliday, G. A. Mahood, P. Holden, J. M. Metz, T. J. Dempster and J. P Davidson. Earth Planet Sci Lett 99:387-389

Spera FJ, Crisp JA (1981) Eruption volume, periodicity, and Caldera area-relationships and inferences on development of compositional zonation in silicic magma chambers. J Volcanol Geotherm Res 11:169-187

Tappa MJ, Coleman DS, Mills RD, Samperton KM (2011) The plutonic record of a silicic ignimbrite from the Latir volcanic field, New Mexico. Geochem Geophys Geosyst 12:Q10011. doi: $10.1029 / 2011 \mathrm{GC} 003700$

Thomas JB, Watson EB, Spear FS, Shemella PT, Nayak SK, Lanzirotti A (2010) TitaniQ under pressure: the effect of pressure and temperature on the solubility of $\mathrm{Ti}$ in quartz. Contrib Mineral Petrol 160:743-759 van den Bogaard P, Schirnick C (1995) Ar-40/Ar-39 laser probe ages of Bishop-Tuff Quartz phenocrysts substantiate long-lived silicic magma chamber at Long-Valley, United-States. Geology 23:759-762

Vazquez JA, Reid MR (2004) Probing the accumulation history of the voluminous Toba magma. Science 305:991-994

Wallace P, Carmichael ISE (1989) Minette lavas and associated leucitites from the western front of the Mexican Volcanic Belt: petrology, chemistry, and origin. Contrib Mineral Petrol 103:470-492

Wallace PJ, Anderson AT, Davis AM (1999) Gradients in H2O, CO2, and exsolved gas in a large-volume silicic magma system: interpreting the record preserved in melt inclusions from the Bishop Tuff. J Geophys Res Solid Earth 104:20097-20122

Wark DA, Watson EB (2006) TitaniQ: a titanium-in-quartz geothermometer. Contrib Mineral Petrol 152:743-754

Wark DA, Hildreth W, Spear FS, Cherniak DJ, Watson EB (2007) Pre-eruption recharge of the Bishop magma system. Geology 35:235-238

Watson EB, Harrison TM (1983) Zircon saturation revisitedtemperature and composition effects in a variety of crustal magma types. Earth Planet Sci Lett 64:295-304

Watson EB, Wark DA, Thomas JB (2006) Crystallization thermometers for zircon and rutile. Contrib Mineral Petrol 151:413-433

Weiland C, Steck LK, Dawson P, Korneev V (1995) Crustal structure under Long Valley caldera from nonlinear teleseismic travel time tomography using three-dimensional ray. J Geophys Res 100:20379-20390

Weis D, Kieffer B, Hanano D, Nobre Silva I, Barling J, Pretorius W, Maerschalk C, Mattielli N (2007) Hf isotope compositions of U.S. Geological Survey reference materials. Geochem Geophys Geosyst 8:Q06006. doi:10.1029/2006GC001473

White SM, Crisp JA, Spera FJ (2006) Long-term volumetric eruption rates and magma budgets. Geochem Geophys Geosyst 7:Q03010. doi:10.1029/2005GC001002

Wiedenbeck M, Alle P, Corfu F, Griffin WL, Meier M, Oberli F, Vonquadt A, Roddick JC, Speigel W (1995) 3 natural zircon standards for U-Th- $\mathrm{Pb}$, Lu-Hf, trace-element and ree analyses. Geostan Newslett 19:1-23

Wilson CJN, Hildreth W (1997) The Bishop Tuff: new insights from eruptive stratigraphy. J Geol 105:407-439

Wilson CK, Jones CH, Gilbert HJ (2003) Single-chamber silicic magma system inferred from shear wave discontinuities of the crust and uppermost mantle, Coso geothermal area, California. J Geophys Res 108(B5):2226. doi:10.1029/2002JB001798

Wolff JA, Ramos FC (2003) Pb isotope variations among Bandelier Tuff feldspars: no evidence for a long-lived silicic magma chamber. Geology 31:533-536

Wotzlaw JF, Schaltegger U, Frick DA, Dungan MA, Gerdes A, Günther D (2013) Tracking the evolution of large-volume silicic magma reservoirs from assembly to supereruption. Geology 41:867-870

Zandt G, Leidig M, Chmielowski J, Baumont D, Yuan X (2003) Seismic detection and characterization of the Altiplano-Puna magma body, central Andes. Pure Appl Geophys 160:789-807 